If you have no further use for this report after it has served your purpose, please return it to the Geological Survey, using the official mailing label at the end.

\begin{tabular}{c}
\hline UNITED STATES DEPARTMENT OF THE INTERIOR \\
IGNEOUS GEOLOGY AND STRUCTURE \\
OF THE \\
MOUNT TAYLOR VOLCANIC FIELD \\
NEW MEXICO \\
GEOLOGICAL SURVEY PROFESSIONAL PAPER 189-B
\end{tabular}



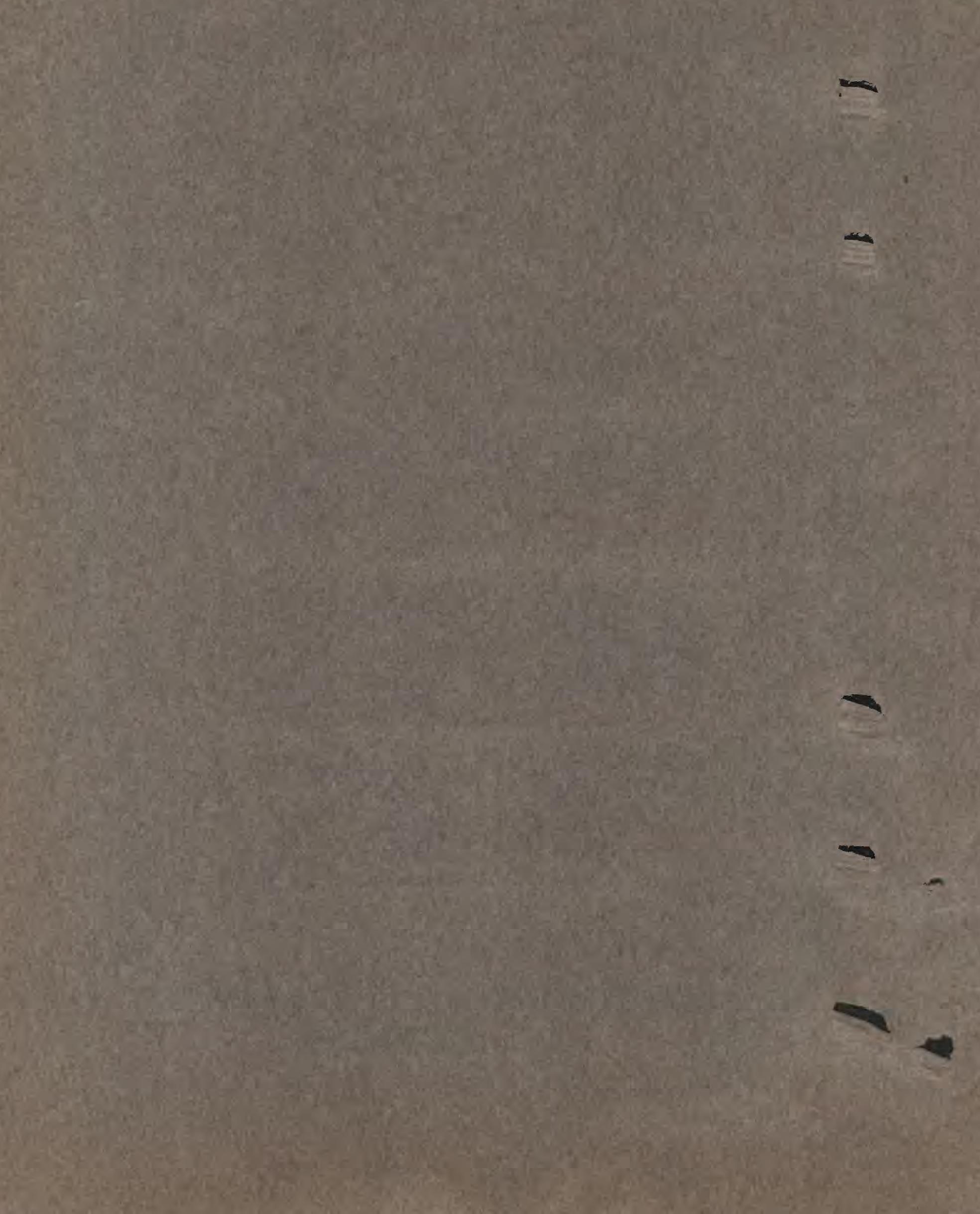


\section{IGNEOUS GEOLOGY AND STRUGTURE OF THE MOUNT TAYLOR VOLCANIC FIELD, NEW MEXICO}

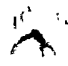

\section{ABSTRACT}

The Mount Taylor volcanic field is situated in northwestern New Mexico and embraces a part of the south flank of the San Juan Basin and the adjoining part of the block-faulted Rio Grande Valley. Most of the volcanic field is in the Colorado Plateau province, but the eastern part is in the Basin and Range province. The boundary between the two provinces is clearly marked topographically and geologically. A variety of land forms and several different types of drainage patterns represented in the area are due to differences in resistance and structural attitude of the rocks.

The sedimentary rocks in the field consist chiefly of Upper Cretaceous sandstone and shale, the Santa Fe formation of late Miocene and Pliocene age, and some younger deposits of probable Pleistocene age; also small areas of the Morrison formation, of Upper Jurassic age. Volcanic rocks were erupted at different times in this area. Probably the first eruptions were those of the Mount Taylor volcano, in Miocene time, which began with rhyolitic tuffs and trachyte, continued with a series of latites, and concluded with porphyritic andesite. The tuffs, trachyte, and latites apparently came from a central pipe and crater in Mount Taylor, but the porphyritic andesite was erupted mostly from fissures radiating from the pipe. The tuff and lava erupted by Mount Taylor accumulated in a cone whose top has been considerably lowered by erosion. The cone is estimated to have included originally at least $12 \frac{1}{2}$ cubic miles of the eruptives.

The Mount Taylor eruptions were followed, probably in Pliocene time, by a large number of basalt sheets erupted by small volcanoes distributed around Mount Taylor. These sheets of basalt were erupted on erosion surfaces cut around the Mount Taylor cone. A few of the sheets preceded the latest flows of porphyritic andesite from Mount Taylor, and one preceded the rhyoly but most of them were erupted after Mount Taylor had become aquiescent. The sheets were supplied by many small volcanoes, mostly of the central type, although a few fissure eruptions are known.

Since the eruptions streams have cut downward nearly 2,000 feet, and the lava sheets now cap high mesas. On these lavacapped mesas the volcanoes are marked by cones of lava and scoriae. Where the lava has been completely removed the old volcanoes are marked by isolated necks. The most conspicuous necks are composed almost entirely of basalt; others include basaltic breccia with the basalt, and still others are mostly basaltic breccia. There is practically no deformation of the country rock adjacent to these intrusions. The breccia is believed to be a nonextruded byproduct of a quiet intrusive process.

Folding has been the predominant type of structural deformation of the rocks in the Colorado Plateau portion of the Mount Taylor volcanic field, but faulting has been the predominant type in the Basin and Range portion. The Mount Taylor eruptions yere preceded by regional northward tilting, by folding of the McCarty syncline, and by folding and associated faulting west of the syncline and gentle warping east of the syncline. Probably most of the displacement along the faults in the Basin and Range part of the field preceded the Mount Taylor eruptions also, but after those eruptions there was renewed minor folding and faulting in the McCarty syncline, minor faulting in the gently warped area east of the syncline, and continued faulting in the eastern part of the volcanic field. The faulting in this part of the area continued during the depcsition of the Santa Fe formation and some deposits that are probably younger than the Santa Fe.

\section{INTRODUCTION} LOCATION OF THE AREA

The Mount Taylor volcanic field, named from Mount Taylor, its largest volcano and most conspicuous topographic feature, includes an area of about 2,000 scuare miles in northwestern New Mexico midway between Albuquerque and Gallup. The area lies north of the valley of the Rio San Jose. This valley is used by the Atchison, Topeka \& Santa $\mathrm{Fe}$ Railway and United States Highway 66 for their approach to the Continental Divide, which crosses the northwest corner c the volcanic field. (See fig. 3.)

From the village of Grant, 15 miles southwert of Mount Taylor, the western and southwestern parts of the volcanic field are easily accessible. A Forest Service road from Grant extends within 4 miles of Mount Taylor Peak. A graded road, not fully showin on. plate 7, leads from Grant to San Mateo, whence other roads lead northward along the west side of Mesa Chivato and eastward onto the mesa. Laguna and the Laguna Indian puebło, south of the field, are the best starting points for visiting the east side of Mount Taylor and Mesa Chivato. Stage roads lead northward as far as Marquez. New Mexico State Highway 6, the most direct road west from Albuquerque, crosses the southeast corner of the area shown on plate 7 . The northern parts of the area can best be reached from San Ysidro, on State Highway 44, or from Cabezon, which is connected by a fair road with that highway.

\section{PRESENT INVESTIGATION}

The field investigation on which this report is linsed was begun in 1930, with the assistance of D. A. Andrews, R. W. Brown, and W. S. Pike, Jr. In that year the portion of the volcanic field north and northwest of Mesa Chivato and also a strip about 10 miles wide along the east side of the mesa, including the many volcanic necks, were mapped, In 1931 the field investigation 
was resumed with the assistance of $H$. R. Joesting, R. C. Becker, J. Wr. Wyckoff, and G. F. Taylor; the country along the south side of Mount Taylor and east of the mountain as far as the eastern border of the Upper Cretaceous formations was mapped.

The field investigations of 1930 and 1931 formed a p.rt of the Geological Survey's regular program of sur- determinations. During these two seasons several trips were made into the flanks of the Mount Taylor volcano, but only very general relations were noted. The numerous volcanic necks northeast of Mount Taylor were examined more carefully in connection with the detailed mapping.

Returning in 1932 , I was able to spend 3 weeks

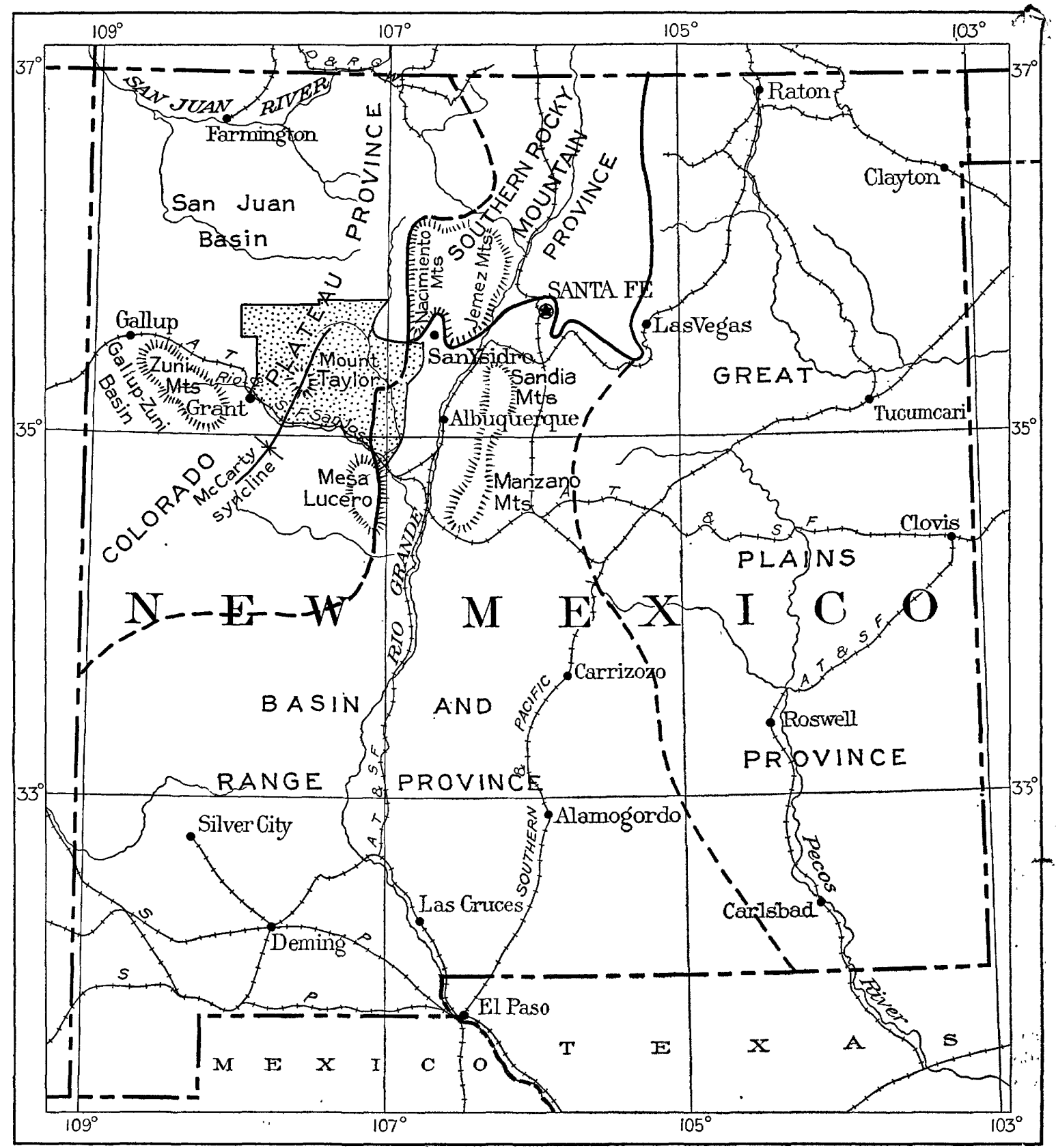

FIGURE 3.-Index map of New Mexico showing the location of the Mount Taylor volcanic field (stippled) and the approximate boundaries of the physiographic provinces.

veys for the clas ification of public lands with reference to fuel and othcr mineral resources. The energies of the field parties were therefore confined mostly to the mapping of the sedimentary rocks. The mapping was done by plane-table methods on a scale of $1: 62,500$ and consisted of careful lateral tracing of formation boundaries and carrying altitudes on these horizons for structural in studying the Mount Taylor volcano and the later eruptives immediately surrounding it. $\dot{I}$ iring this study sketch maps were made of the field retations, and another week was spent in obtaining additional information on the volcanic necks east of Mesa Chivato.

The present report therefore includes the results of both detailed and reconnaissance studies, and in the 


\section{CONTENTS}

Page

Abstract

Introductigntan

Location of the area.

Presønt investigation

Previous investigations _

Geography

Geomorphic location

Land forms _.

Drainage.

Climate and vegetation

Sunimary of the late Tertiary and Quaternary history

Chron.sivgy of events.

Age a amignments

Volcanic activity

General chronology _ $\ldots \ldots \ldots$

The Mount Taylor volcano._.

Rhyolitic tuff

Trachyte....

Latite series

Porphyritic andesite series _...

Summary of Mount Taylor eruptions

Sheet basalt_...

Basalt in the amphitheater

Vents on the north flank of Mount Taylor

Flows on Mesa Chivato _...

La Jara Mesa.

Grant Ridges.....

Horace Mesa

The volcanic necks.

Cabezon Peak

Cerro de los Cuates.

Neck in Gonzales Canyon

La Señora Peak _.

Seboyeta Peak ...

Basaltic rocks by New Mexico State Highway 6

Sierra Alesna

Other volcanic necks

Basalt dikes

Origịn of the breccia

Summary of basalt eruptions

Recent flows

Structural geology

General structural relations of the volcanic field

Colorado Plateau portion of the field

McCarty syncline.

Minor folds within McCarty syncline.

Fo'd; northwest of McCarty syncline

Gevile warping east of McCarty syncline

Basin and Range portion of the field.

General structural relations

Faults

Folds

Age of the deformation

Possible significance of the structural features

Index _ . 


\section{İLLUSTRATIÒNS}

Plate 7. Map showing structure and reconnaissance areal geology of the volcanic rocks of the Mount Taylor N. Mex ...... In pocket

8. $A$, View of Mount Taylor; $B$, View looking northeast across erosion surface in Lobo Canyon

9. Map showing drainage in Mount Taylor volcanic field . .

10. $A$, Porphyritic andesite flows near base of north flank of Mount Taylor; $B, V$-shaped valley cut in porphyritic andesite. ...

11. $A$, Cross section of basaltic neck exposed by erosion in Grant Ridges; $B$, Cliff face exposing basaltic breccia on rhyolitic tuff near the volcanic neck.

12. $A$, Basaltic lava and cinder cone on the sheet basalt capping Horace Mesa; $B$, View looking northeast from top of volcanic neck east of La Abra de los Cerros; $C$, View looking south from Cerro de los Cuates.............

13. A, Cabezon Peak viewed from the bluffs above the village of Cabezon; $B$, Closer view of south side of Catezon Peak showing fairly uniform vertical columns capped with a layer of scoriaceous basalt

14. A, Volcanic neck east of La Abra de los Cerros; $B$, Xenolith of fossiliferous Cretaceous sandstone in basaltic br $3 c a^{2}$ in neck in Gonzales Canyon.

15. $A, B$, Views of Evans Peak

16. $A$, View looking southwest toward Seboyeta Peak; $B$, Xenoliths of sedimentary rock in breccia along east side of Seboyeta Peak.

17. $A$, Dike of basalt and basaltic breccia intruding Cretaceous shale; $B$, Banded basaltic breccia lying at outer contact of large breccia mass; $C, D$, Angular unconformity between Santa Fe formation and underlying Cretaceous rocks

18. $A$, Block diagram showing structural surface of part of Antonio Sedillo Grant at southwest corner of the are?; $B$, Block diagram showing structural surface of most of north half of Basin and Range part of Mount Taylor volcanic field

19. $A$, Flat-lying unbroken Santa Fe formation crossing a normal fault in Cretaceous shale; $B$, Basaltic lava in Santa Fe formation tilted and broken by small fault

Piafre 3. Index map of New Mexico showing location of Mount Taylor volcanic field

4. Diagrammatic view of part of Mount Taylor volcanic field

5. Sketch showing topographic relations in Lobo Canyon

6. Pedestal of alluvium about 50 feet high left standing in Chico Arroyo, 3 miles west of Cerro de los Cuates........

7. Arroyo of Rio Puerco 2 miles north of Ojito ranch

8. Sequence of late Tertiary and Quaternary events in Mount Taylor volcanic field .

9. Hypothetical profile of Mount Taylor

10. Geologic sketch map of amphitheater and surrounding rim of Mount Taylor volcano

11. Sketch map showing intrusive basaltic breccia in Gonzales Canyon

12. Diagrammatic section through north side of Juan Tafoya Peak

13. Diagram of columnar jointing in intrusions 4 miles east-northeast of La Señora Peak

14. Sketch from photograph showing fault relations half a mile west of San Ysidro and 1,000 feet north of State 1 ighhway 44

15. Diagrammatic section illustrating faulting east of Mesa Lucero

IV 
descriptions an effort is made to indicate the degree of completeness of the observations.

\section{PREVIOUS INVESTIGATIONS}

Numerous reports contain references and descriptions of the Mount Taylor volcanic field. The earliest describe the general appearance of the area as viewed from the nearby routes of travel. Subsequent reports give fuller accounts of the gèology, but most of them were written to emphasize some specific problem of the area. The reports are summarized as follows:

Simpson, J. H., Journal of a military reconnaissance from Santa Fe, N. Mex., to the Navajo country: 31st Cong., 1st sess., S. Ex. Doc. 64, pp. 56-138, 146-148, 1850. Mount Taylor is named in honor of the President, and there is brief mention of the kinds of rock encountered along the line of march.

Marcou, Jules, Résumé of a geological reconnaissance extending * * * to the Pueblo de los Angeles in California: U. S. Pacific R. R. Expl., 33d Cong., 2d sess., S. Ex. Doc. 78, vol. 3, pt. 4, pp. 165-171, 1856. Mount Taylor is identified as a volcanic cone. On the basis of fossils Jurassic and Cretaceous ages are assigned to the older rocks exposed in the valley south of Mount Taylor.

Marcou, Jules, Geology of North America, Zurich, 1858. This report contains the first geologic map and cross section of this part of the country. In the cross section Mount Taylor is shown as a volcano.

Newberry, J. S., Geological report, in Ives, J. C., Report upon the Colorado River of the West, pt. 3, pp. 65-66, 1861. Contains a description of Mount Taylor as viewed from the San Jose Valley.

Newberry, J. S., Geological report, in Macomb, J. N., Report of the exploring expedition from Santa Fe, N. Mex., to junction of the Grand and Green Rivers of the great Colorado of the West in 1859, pp. 9-118, 1876. Describes the appearance of Mount Taylor as viewed from the northeast corner of the volcanic field.

Howell, E. E., U. S. Geog. and Geol. Surveys W. 100th Mer. Rept., vol. 3, pp. 227-301, 1875. Recognizes the fact that the eruptions of the Mount Taylor volcano were later than the folding of the Cretaceous strata and that the sheet basalts were later than Mount Taylor. Also calls attention to faulting in the eastern part of the area.

Dutton, C. E., Mount Taylor and the Zuñi Plateau: U. S. Geol. Survey 6th Ann. Rept., pp. 105-198, 1885. The first complete desc tion of the geology of the volcanic field is in this report. Discussion is centered around the volcanic rocks, however, with only passing mention of the sedimentary rocks. Includes a very satisfactory geologic map with topographic contours covering Mount Taylor and the Zuñi Mountains.

Emmons, S. F., and others, Geological guidebook of the Rocky Mountain excursion (5th Internat. Geol. Cong., Washington, 1891), pp. 468-471, John Wiley \& Sons, 1893 . Includes a description, by G. K. Gilbert, of the appearance of the Mount Taylor area as viewed from the Rio San Jose.

Herrick, C. L., The geology of the San Pedro and Albuquerque districts [N. Mex.]: Denison Univ., Sei. Lab., Bull., vol. 11, pp. 93-116, 1898. Discusses stratigraphy of the Cretaceous strata.

Herrick, C. L., and Johnson, D. W., The geology of the Albuquerque sheet [N. Mex.]: Denison Univ., Sci. Lab., Bull., vol. 11, art. 9, pp. 175-239, 1900; New Mexico Univ., Hadley Lab., Bull., vol. 2, pt. 1, pp. 1-67, 32 pls., with colored geologic map, 1900. Discusses stratigraphy and paleontology of the Cretaceous ta.

Herrick, C. L., Reports of a geologic reconnaissance in western
Socorro and Valencia Counties, N. Mex.: Am. Geologirt, vol. 25, pp. 331-346, pls. 8-60, 1900 . Discusses stratigraphy of the Cretaceous strata.

Johnson, D. W., Block mountains in New Mexico: Am. Geologist, vol. 31, p. 137, 1903. Briefly mentions block faultins along the Rio Puerco in relation to the regional structure bf the Rio Grande Valley at Albuquerque.

Reagan, A. B., Geology of the Jemez-Albuquerque region, N. Mex.: Am. Geologist, vol. 31, pp. 67-111, 7 pls., 1903; Indiana Acad. Sci. Proc., 1902, pp. 187-197, 1903. Briefly montions Cretaceous stratigraphy of the eastern part of the area in connection with regional correlation.

Schrader, F. C., The Durango-Gallup coal field of Colorado and New Mexico: U. S. Geol. Survey Bull. 285, pp. 24.1-258, 1906. Demonstrates the continuity of the coal field batween Durango, Colo., and Gallup, N. Mex.

Johnson, D. W., Volcanic necks of the Mount Taylor region, N. Mex.: Geol. Soc. America Bull., vol. 18, pp. 303-324, 1907. Demonstrates that the volcanic necks east of Mesa Chiv to are correctly interpreted as such and are not remnants of flows or laccoliths.

Shimer, H. W., and Blodgett, M. E., The stratigraphy of the Mount Taylor region, N. Mex.: Am. Jour. Sci., 4th ser., vol. 25, pp. 53-67, 1908. Describes and discusses significance of fossils collected during the measurement of three seetions of Cretaceous rocks in the Rio Puerco Valley.

Gardner, J. H., The coal field between Gallup and San Mateo, N. Mex.: U. S. Geol. Survey Bull. 341, pp. 364-378; 190?; The coal field between San Mateo and Cuba, N. Mex.: U. S. Geol. Survey Bull. 381, pp. 461-473, 1910. The coal-bearing Mesaverde formation is traced from Gallup to Cuba acrosa the northern part of the volcanic field.

Darton, N. H., A reconnaissance of northwestern New I Aexico and northern Arizona: U. S. Geol. Survey Bull. 435, p. 69. 1910. Gives general statements conceraing the stratigraphy and structure of the eastern part of the Mount Taylor area.

Lee, W. T., Stratigraphy of the coal fields of northern central New Mexico: Geol. Soc. America Bull., vol. 23, pp. 62`-629, 1912. Discusses the regional correlation of the Upper Cretaceous formations present in the area.

Stanton, T. W., Some variations in Upper Cretaceous stratigraphy: Washington Acad. Sci. Jour., vol. 3, pp. 60-61, 1913. Discusses the regional correlation of the Upper Cretaceous formations present in the area.

Lee, W. T., Relations of the Cretaceous formations to the Rocky Mountains in Colorado and New Mexico: U. S. Geol. Survey Prof. Paper 95, pp. 27-58, 1916. Discusses the rexional correlation and sedimentation of the Upper Cretaceous formations in this area.

Lee, W. T., and Knowlton, F. H., Geology and paleontology of the Raton Mesa and other regions in Colorado and New Mexico: U. S. Geol. Survey Prof. Paper 101, pp. 195-198, 1917. Discusses the regional correlation of the Upper Cretaceous formations present in this area.

Darton, N. H., Geologic structure of parts of New Mexico: U. S. Geol. Survey Bull. 726, pp. 257-265, 1922; "Red Beds" and associated formations in New Mexico: U. S. Geol. S urvey Bull. 794, pp. 109-137, 1928. Describes the regional structure of the southern part of the area.

Bryan, Kirk, Historic evidence on changes in the channel of the Rio Puerco, a tributary of the Rio Grande in New Mexico: Jour. Geology, vol. 36, pp. 265-282, 1928. Evidence shows that before 1885 the valley floor of the Rio Puerco was $\varepsilon$ true flood plain. Between 1885 and 1890 the channel was dee rened and widened, a process still continuing. Six small towns have been abandoned, and the others impoverished by the erosion, 


\section{GEOGRAPHY}

\section{GEOMORPHIC LOCATION}

The Mount Taylor field overlaps the southeast border of the San Juan Basin and the northwest border

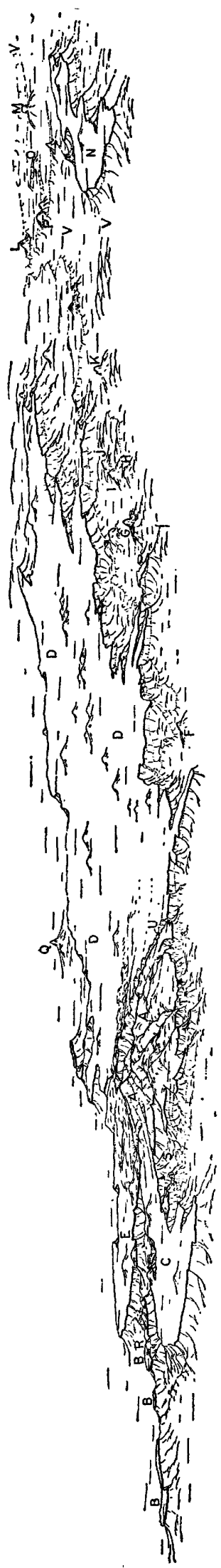

อี สี

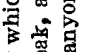

政要

कี

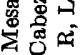

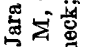

जิ

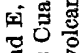

要

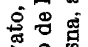
of the block-faulted Rio Grande Valley. (See fig. 3.) It therefore includes portions of both the Colorado Plateaus and the Basin and Range provinces. The boundary between these two provinces is clearly marked geologically in the area, a feature of some interest in view of the uncertain boundary that must generally be drawn elsewhere in the State. The northeastern part of the area adjoins the Nacimiento uplift of the Southern Rocky Mountain province.

\section{LAND FORMS}

The most prominent topographic feature in the area is the mountain for which the field was named. Viewed from a distance Mount Taylor has a distinctly conical form, with extensive flat-topped foothills spreading away from its base. (See pl. 8, $A$, and fig. 4.) The top of the cone consists of a series of peaks distributed along an arc concave to the east. Mount Taylor Peak, the highest, stands on the west side of the arc and rises about 11,350 feet above sea level, a mile higher than the Rio San Jose 12 miles to the south. Within the arc is the crater of the old volcano. The crater has been enlarged by erosion to form an amphitheater covering nearly 5 square miles and about 2,500 feet deep, drained eastward by Water Canyon Creek, which has cutits way through the east flank of the cone. In this report the term "Mount
Taylor" refers to the whole conical mountain mass and thus includes all the peaks in the arc, the amphitheater, and the rugged slopes down to the level of the foothills. The highest peak is called Mount Taylor Peak.

Mount Taylor is surrounded by broad, flat-topped foothills capped with sheet basalt. (See fig. 4.) Mesa Chivato, the largest, extends northeastwar for about 25 miles from the base of Mount Taylor and at most places is more than 10 miles wide. From a distance Mesa Chivato appears as a nearly flat plateau, but closer views reveal scores of lava and cinder cones, some a few hundred feet high, marking the vents that supplied the basaltic lava cap. The top of the mesa is about 2,000 feet above the surrounding country and 3,000 feet below the peaks on Mount Taylor. The northern, eastern, and western limits of Mesa Chivato are distinct geologically and topographically, but the southern limit will be drawn arbitrarily at Water Canyon and the canyon that heads southeast of San Mateo.

South of Mount Taylor flat-topped foothills capped with lava, mostly basalt, extend 10 miles from the base of the cone to the valley of the Rio San Jose, the principal stream of this part of the area. These foothills, deeply dissected by canyons, are exceedingly rough. San Fidel Mesa, between Water and Rinconada Canyons, is somewhat lower than Mesa Chivato, but Horace and La Jara Mesas, southwest of Mount Taylor, have about the same altitude as Mesa Chivato and slope gently away from Mount Taylor. The Grant Ridges are smaller isolated mesas along the northwest side of the valley heading northeast of Grant. Mesa Prieta, 15 miles east of Mesa Chivato, is another high mesa crpped with basalt, but its top is considerably below Mesa Chivato.

The boundaries of the foothills around Mount Taylor are located with fair accuracy on plate 7 , but no instrumental control was extended to the tops of the broad foothills. The topography of Mount Taylor as shown on plate 7 was sketched without instrumental control on the United States Geological Survey rec mnnaissance topographic map. The map, as thus modified, represents some improvement over the earlier rec mnnaissance map but still leaves much to be desired in the way of precise locations and delineation of land forms.

The lavas capping the mesas are the mcst resistant rocks in the area. Erosion of the mesas has progressed almost entirely by removal of the relatively soft sedimentary rocks, thus undercutting the resistant lava caps.

Erosion by the Rio Puerco has produced a hroad valley nearly 2,000 feet below the lava-capped Meras Chivato and Prieta. The sedimentary rocks in the valley have been eroded to low relief, which emphasizes th eheight of a dozen peaks, volcanic necks of resistant lava, some of which rise nearly 2,000 feet above the valley bottom. (See pl. 12, C.)

Elsewhere in the Mount Taylor volcanic field the surface rocks are entirely sedimentary and consist of moderately resistant sandstones interbedded with thicker bodies of easily eroded shale. The character of 


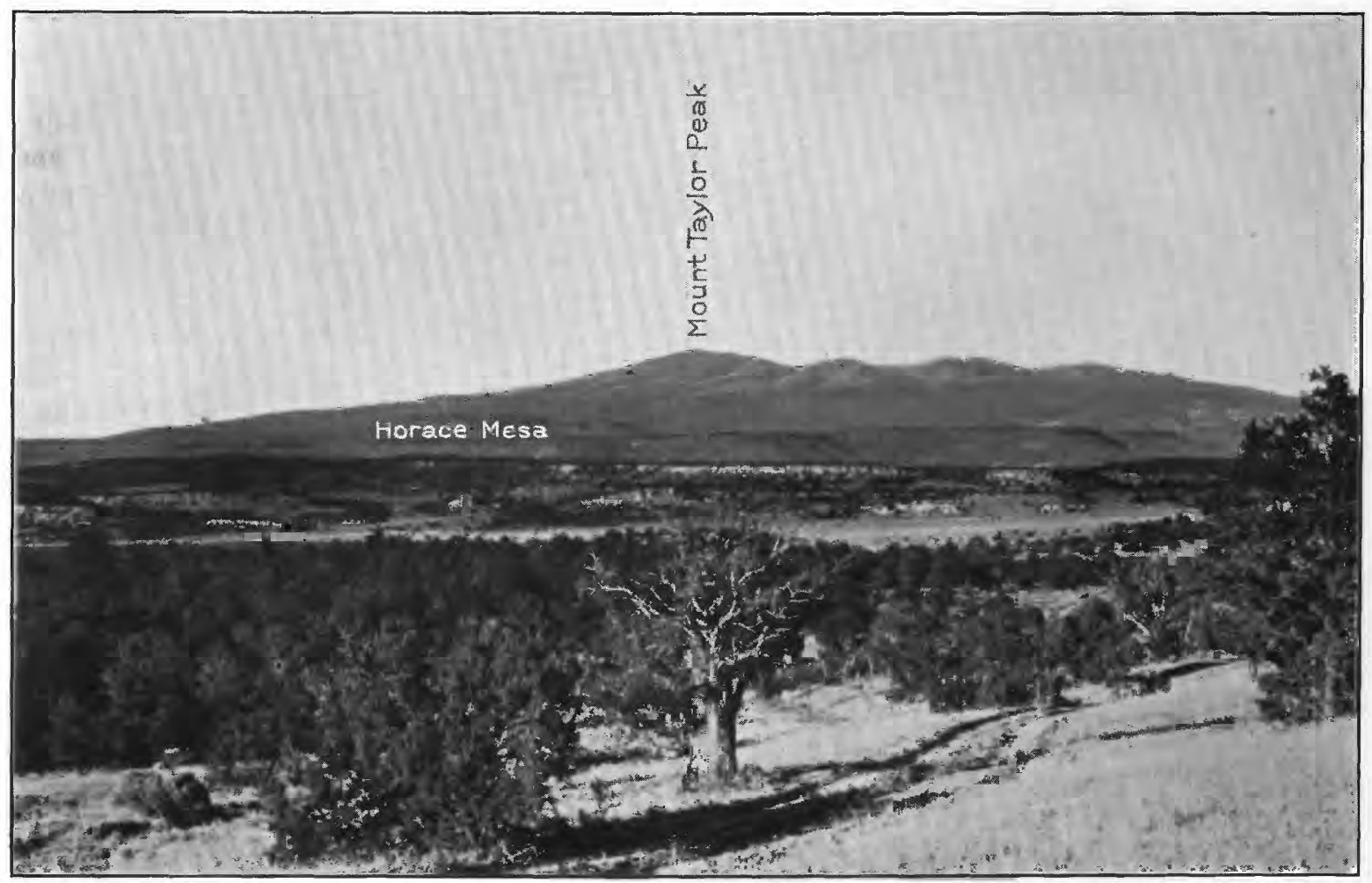

A. VIEW OF MOUNT TAYLOR FROM A POSITION 25 MILES TO THE SOUTH.

Photograph by W. S. Pike, Jr.

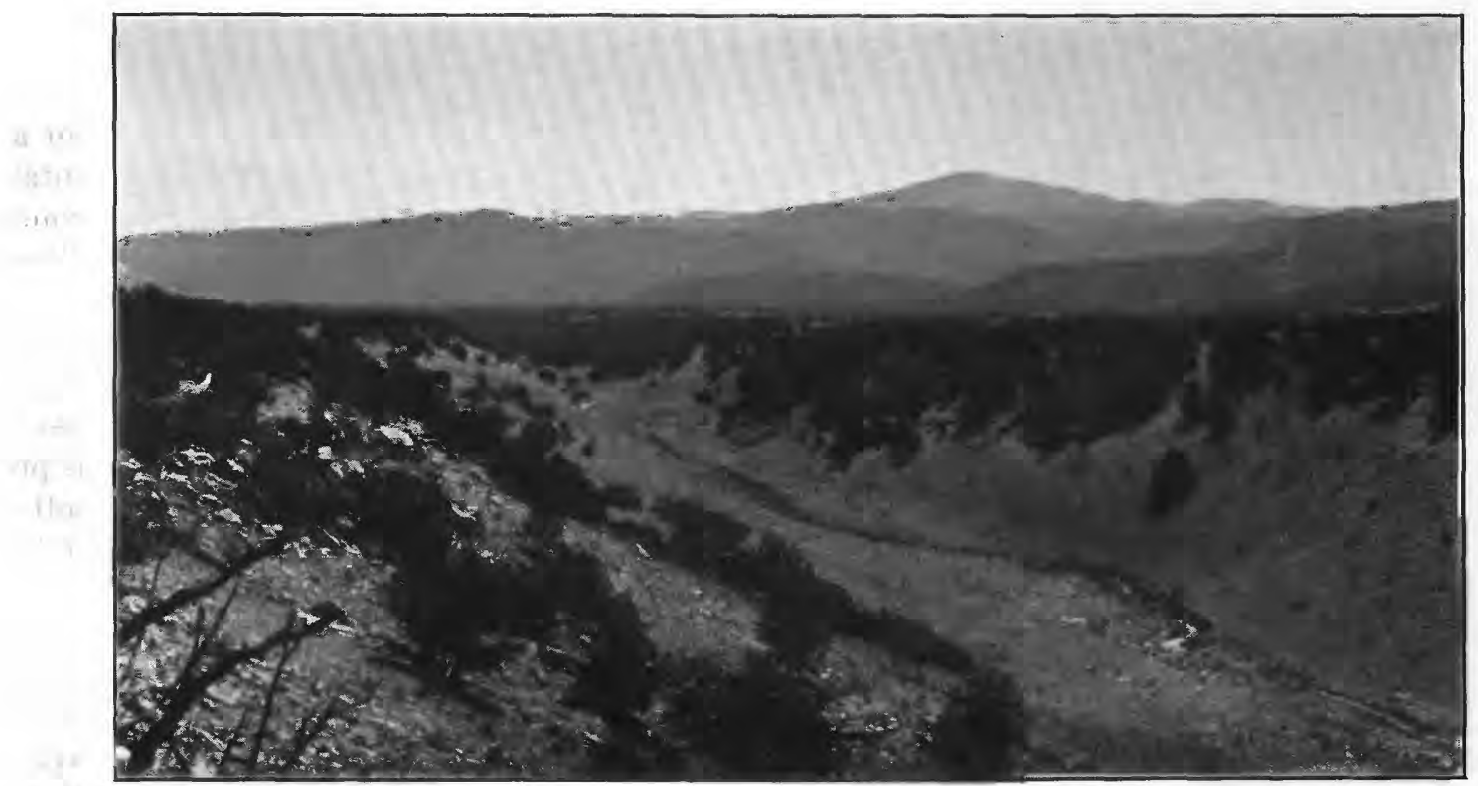

B. VIEW LOOKING NORTHEAST ACROSS EROSION SURFACE IN LOBO CANYON.

This surface, capped with a very thin mantle of gravel, truncates northeastward-dipping beds of sandstone and shale. The high peak in the distance is Mount Taylor. 


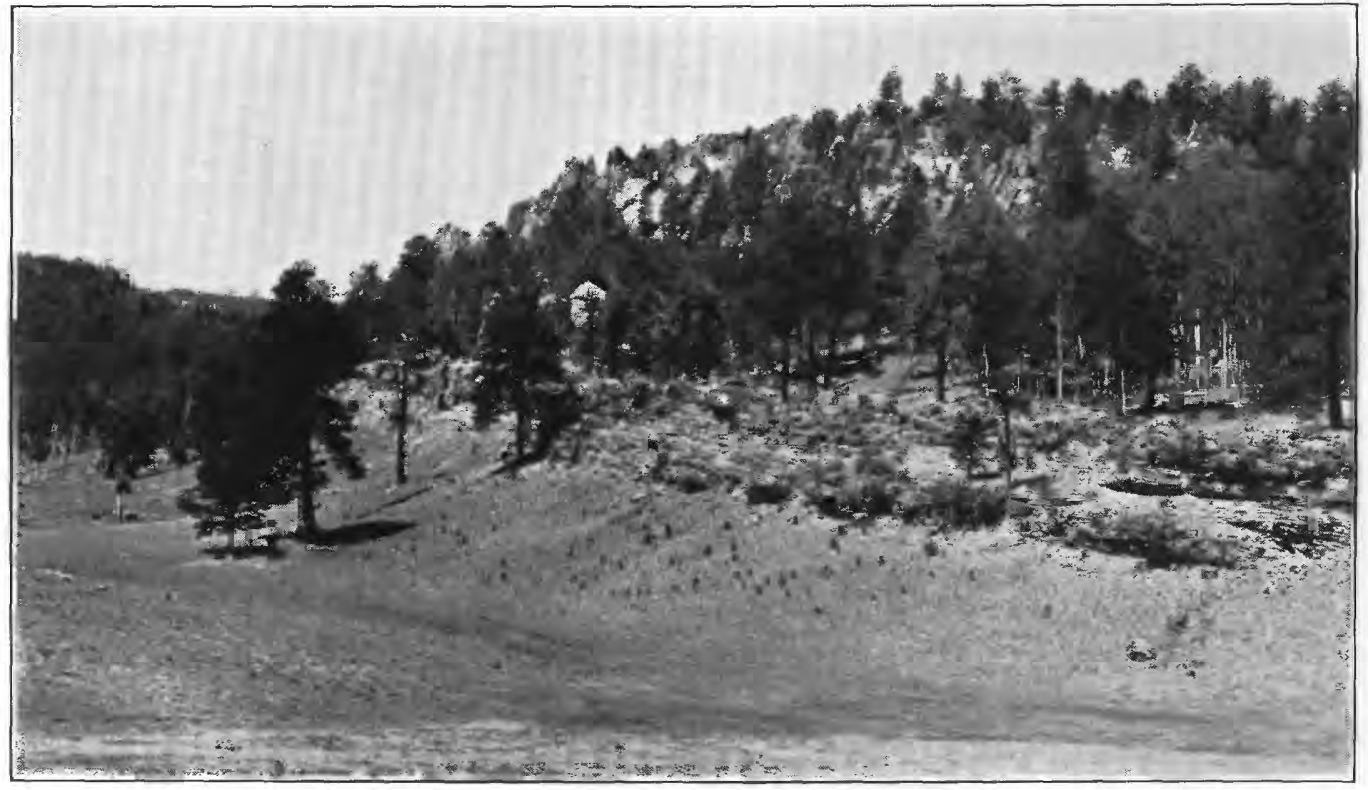

A. PORPHYRITIC ANDESITE FLOWS NEAR BASE OF NORTH FLANK OF MOUNT TAYLOR.

View looking southwest near center of south line of sec. 9, T. 12 N., R. 7 W.

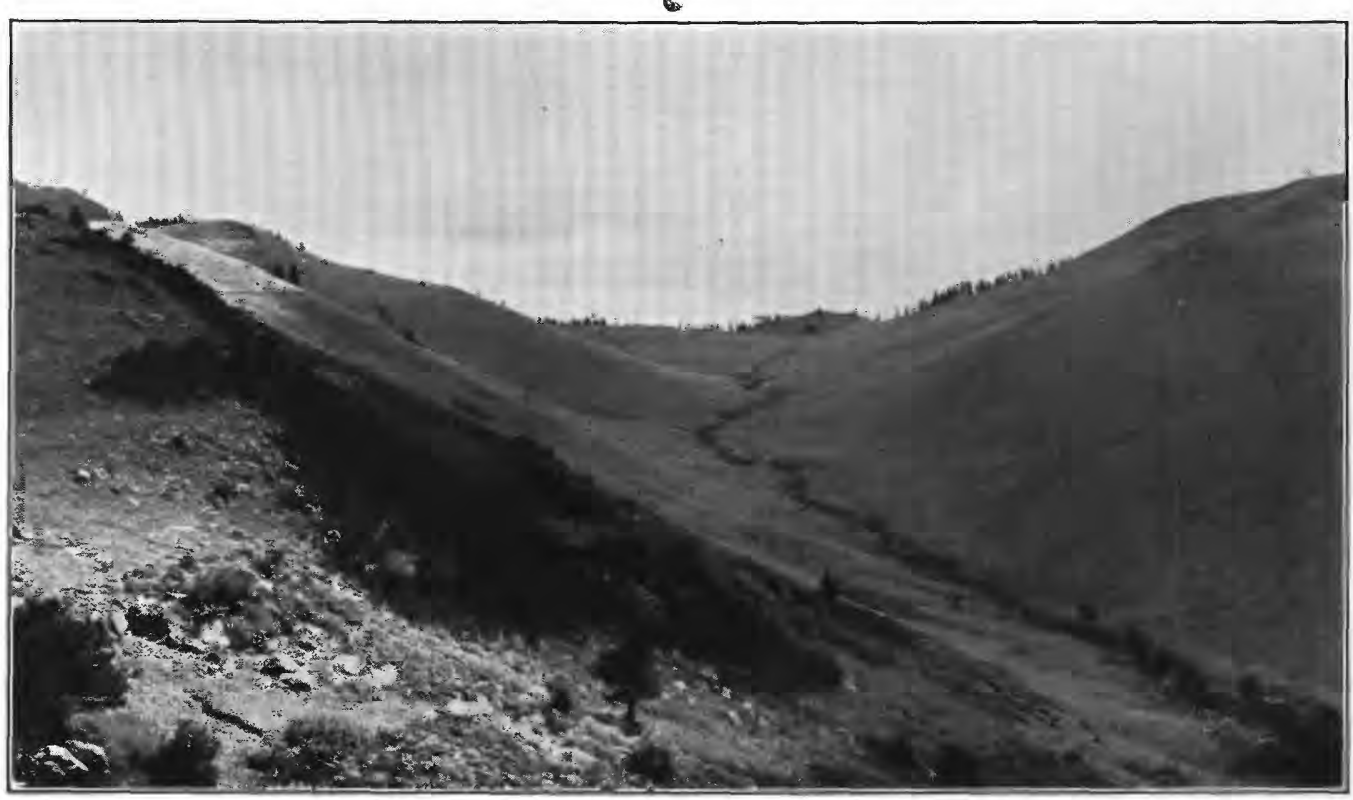

B. V-SHAPED VALLEY CUT IN PORPHYRITIC ANDESITE.

View near center of south line of sec. 31, T. 12 N., R. 7 W. The sky line at the head of the valley marks the rim of the amphitheater of the Mount Taylor volcano. 


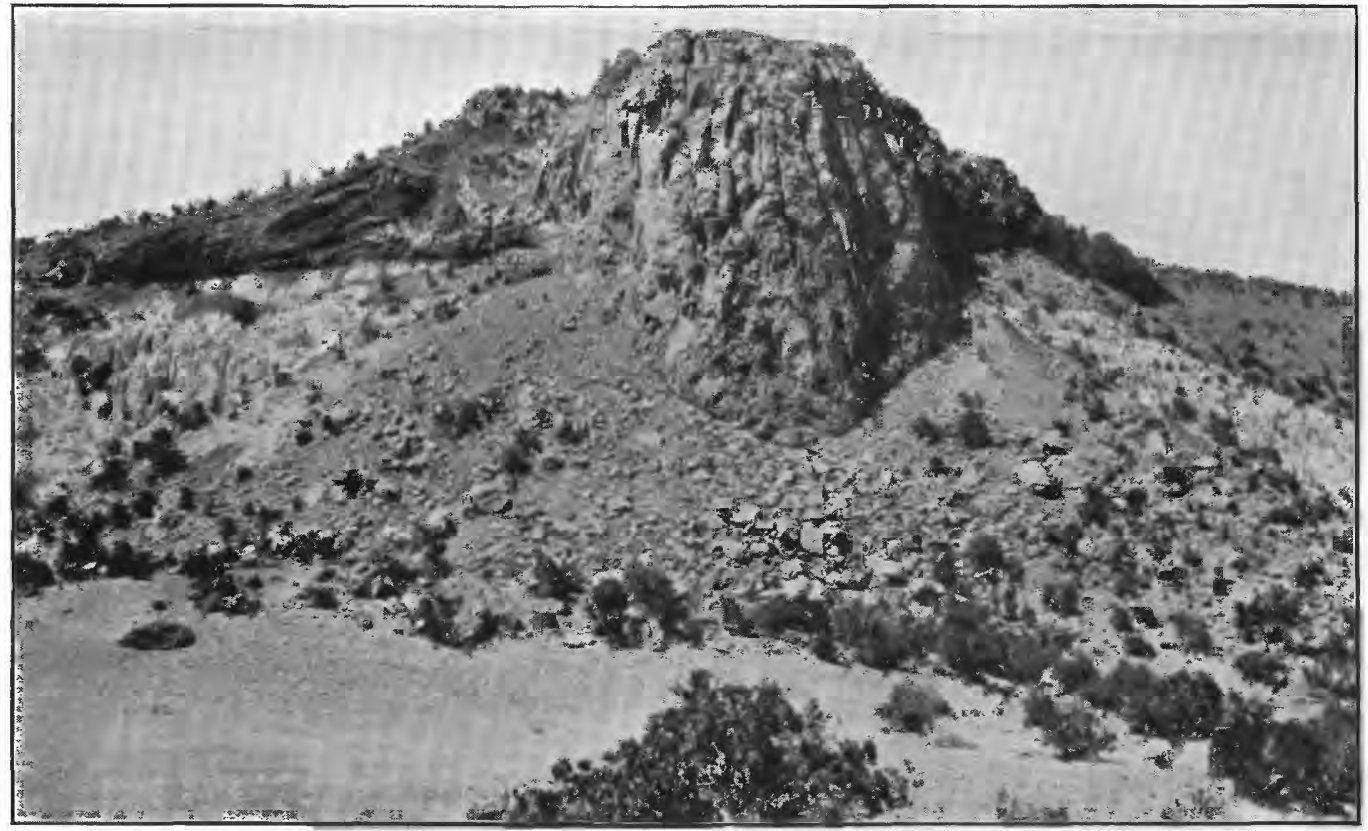

A. CROSS SECTION OF BASALTIC NECK EXPOSED BY EROSION IN GRANT RIDGES, 6 MILES NORTHEAST OF GRANT. View looking southwest in sec. $3, \mathrm{~T}$. 11 N., R. $9 \mathrm{~W}$. Basalt in core is jointed in vertical columns and surrounded by a thin zone of platy jointing developed along the
contact with white tuff. Bedded breccia overlies the tuff, and basaltic lava overlies the breccia on the far side of the cone. The tuff, chiefly rhyolitic, was erupted from Mount Taylor.

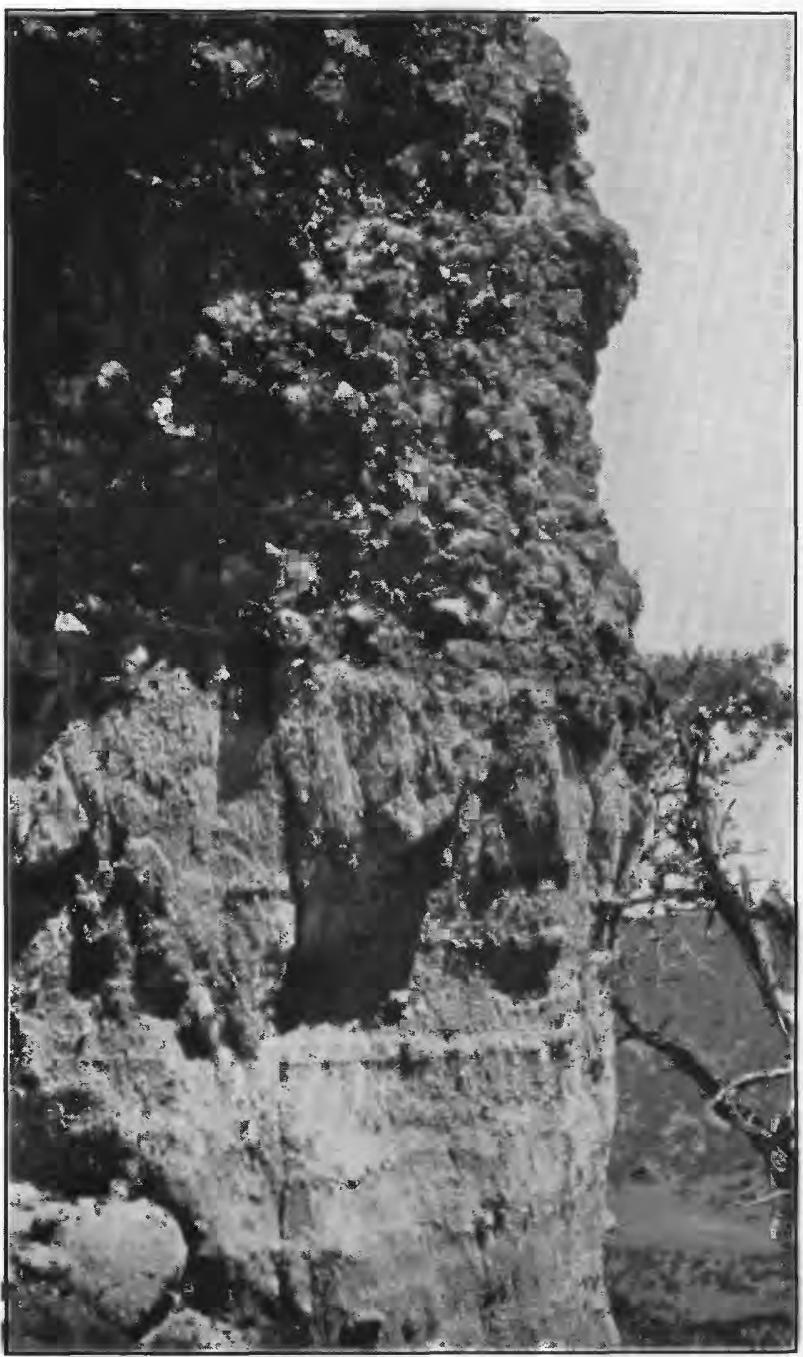

B. CLIFF FACE EXPOSING BASALTIC BRECCIA ON RHYOLITIC TUFF NEAR THE VOLCANIC NECK. In sec. 3, T. 11 N., R. 9 W. 
the topography has been controlled by the number, thickness, and structural attitude of the sandstones. Northwest and southeast of Mount Taylor, where there are many thick beds of sandstone with gentle dips, there are prominent mesas with steplike benches around them. In the eastern part of the volcanic field a miniature Basin and Range topography has been formed where thick sandstone beds, steeply tilted in successive fault blocks, produce sharp parallel ridges between valleys eroded in the shale.

Lobo Canyon contains a notable exception to the general rule of structural control of the topography; there an erosion surface that slopes southwest smoothly truncates folded beds of sandstone and shale. (See pl. 8, $B$, and fig. 5.) A small, inconspicuous remnant of this age has been diverted to join a tributary nearer the head of the master stream, the Rio San Jose.

\section{DRAINAGE}

The variety of land forms determines an equal variety of drainage patterns. Plate 9, showing the drrinage system in the volcanic field, reveals four conspicuous types of pattern, and there are numerous minor variations in each type.

The Rio San Jose and Rio Puerco are the master streams draining the volcanic field. The Rio San Jose flows eastward with an average gradient slightly less than 25 feet to the mile and joins the Rio Puerco at the southeast corner of the field. The Rio Puerco flows southward across the eastern part of the field with an average gradient of about 20 feet to the mile.

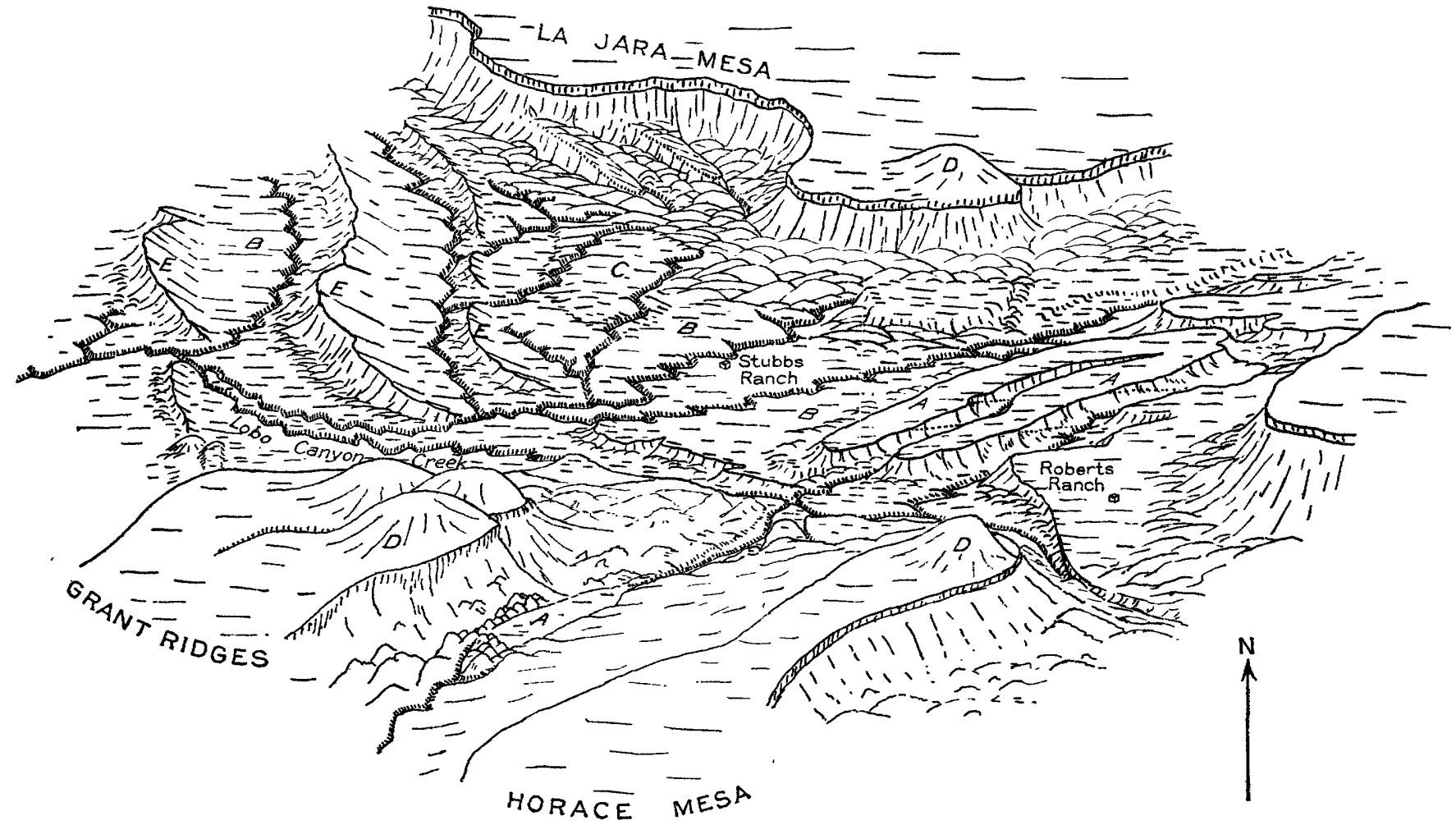

FraURe 5.-Sketch showing topographic relations in Lobo Canyon. The erosion surface (A) was developed by drainage that formerly went southwest between the Grant Ridges and Horace Mesa. Lobo Canyon Creek, which now flows aronnd the northwest side of the Grant Ridges, trenches an alluvial plain (B). An alluvial far (C) has been built out on the plain. Hogbacks of eastward-dipping Upper Cretaceous formations (E) protrude above the alluvium. Sheet basalt or andesite caps the high mesas, above which rise basaltic lava cones (D) that mark the vents from which the lava forming the sheets was erupted.

surface (A, fig. 5) lies south of Lobo Canyon Creek between the Grant Ridges and Horace Mesa. This outlier is on the divide between Lobo Canyon and streams draining to the southwest. Earlier drainage on the surface probably went southwestward from Lobo Canyon, between the Grant Ridges and Horace Mesa. Landslides in the narrow canyon that separates the Grant Ridges from Horace Mesa may have diverted the drainage to form Lobo Canyon Creek, which now flows around the northwest side of the Grant Ridges. This hypothesis is suggested by the accumulation of lava boulders, some 20 feet in diameter, along the south edge of the outlier and also by the presence of numerous landslides along the southwest side of Horace Mesa. The conditions are unusual, however, in that the drain-
In the southwest quarter of the field streams vith a radial pattern drain Mount Taylor. The amphitheater, at the hub of the radial pattern, is drained by Water Canyon Creek. This creek receives numorous headward tributaries in the amphitheater, and the arcuate divide separating the heads of these tributaries from the heads of surrounding streams include the series of peaks that form the summit of Mount Taylor. The valley bottoms of most of these radial streams are relatively wide and flat in the lower courses (pl. 10, A) but are commonly narrow and $V$-shaped toward their heads (pl. 10, $B$ ).

A group of nearly parallel streams flow northeastward on a dip slope of resistant sandstone in T. 15 N., Rs. 8 and $9 \mathrm{~W}$. Where the sandstone passes beneath the 
overlying and more easily eroded shale the streams unite and meander widely in broad flood plains prior to joining the Chico Arroyo.

The drainage has a crudely dendritic pattern at the northwest corner of the volcanic field, on the Pacific side of the Continental Divide. A similar pattern is better developed at the northeast corner of the field, where tributaries of the Rio Puerco and Chico Arroyo flow in broad shale valleys between discontinuous sandstone ridges.

A rectangular drainage pattern has developed in the tributaries of the Rio Puerco in the block-faulted southeastern part of the volcanic field. The river and its principal tributaries have, in general, cut across the structural trends, but the second-order tributaries distinctly follow the fault-line valleys. Where the streams flow across the Tertiary deposits, however, there is no structural control, because most of these beds are later

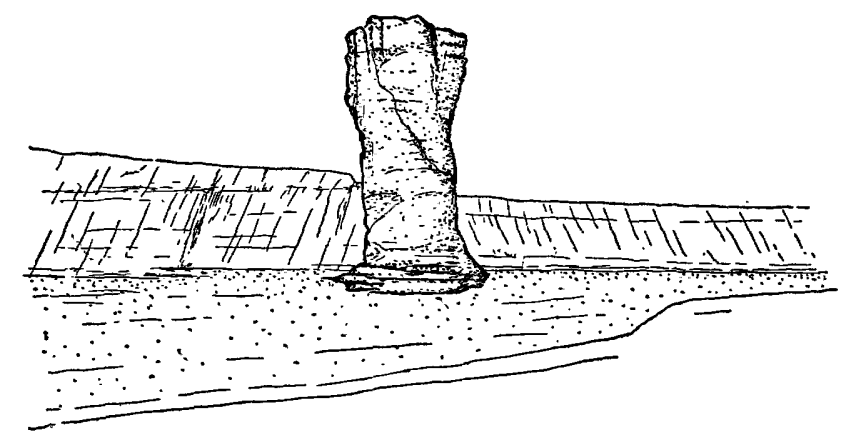

Figure 6.- Pedestal of alluvium about 50 feet high left standing in Chico Arroyo, 3 miles west of Cerro de los Cuates. Probably the result of the cutting off of meander while the arroyo was narrower. Sketch from a photograph.

than the faulting and consist of relatively homogeneous material in which the stream courses are not controlled.

Nearly all the streams in the Mount Taylor volcanic field once flowed on broad alluvial flood plains, but they are now entrenched in arroyos that are cut in the alluvium. Some of the arroyos are 50 feet deep (fig. 6). This erosion has lowered the water table and impoverished the country by impairing the growth of plants dependent on ground water. Bryan ${ }^{1}$ has effectively described the result of arroyo cutting by the Puerco and pointed out, among other disastrous effects, the abandonment of six small towns in the eastern part of this volcanic field. The ruins of the settlements are still to be seen along the flood plain, and some of the houses are being undercut and removed by widening of the arroyo (fig. 7).

\section{CLIMATE AND VEGETATION}

The climate of the Mount Taylor volcanic field is arid. No measurements of rainfall have been recorded very near the field, but the average for western New Mexico is generally given as ranging from 10 to 15

\footnotetext{
1 Bryan, Kirk, Historic evidence on changes in the channel of the Rio Puerco, a tributary of the Rio Grande in New Mexico: Jour. Geology, vol. 36, p. 281, 1928.
}

inches. ${ }^{2}$ There is some variation of rainfall within the field, for Mount Taylor rises several thousand feet above the surrounding area and receives numerous local showers that do not extend to the lower country. The daily range of temperature is considerable. In the summer the nights are cool but the days are warmed by a persistent sunshine. Local rains are frequent in the summer, and the temperature may change quickly at any locality clouded and showered by a storm. In winter freezing temperatures are reported as common at night but the abundant sunny days are commonly balmy.

Most of the volcanic field is less than 7,500 feet above sea level and is within the Upper Sonorar life zone. Over most of this part of the field sagebrush, the picturesque cane cactus, and several other cacti and yuccas are associated with the junipers, nut pines, and grama grass that characterize the life zone. The broad flattopped foothills around Mount Taylor and most of Mount Taylor itself to an altitude of about 9,500 feet support an open, grassy forest, chiefly of yellow pine,

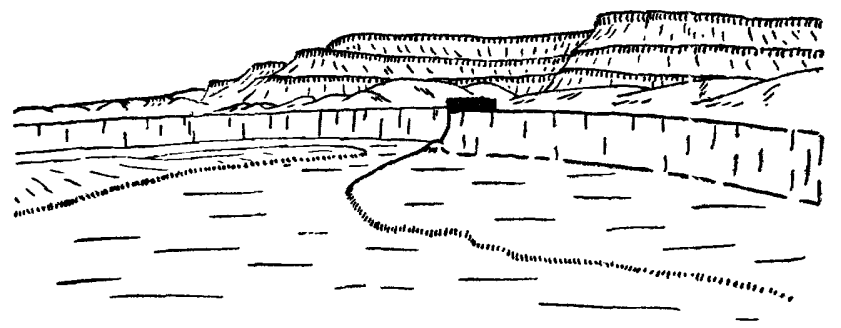

Figure 7.-Arroyo of Rio Puerco 2 miles north of Ojito ranch. T'je arroyo here is about 50 feet deep and is gradually being cut laterally under the house built on the alluvial flood plain. Sketch from a photograph.

which is characteristic of the Transition zone. Above this is the Canadian zone, containing mainly spruces, firs, and aspens.

\section{SUMMARY OF THE LATE TERTIARY AND QUATERNARY HISTORY}

CHRONOLOGY OF EVENTS

The sequence of late Tertiary and Quaternary events in the Mount Taylor volcanic field is summarized diagrammatically in figure 8 .

\section{AGE ASSIGNMENTS}

The Santa Fe formation is of considerable assistance in studying the chronology of events in the Mount Taylor volcanic field and provides the onl r evidence for determining their approximate age. The formation is generally regarded as of upper Miocene and Pliocene age, on the evidence of vertebrate fossils collected by earlier investigators from the formation near Santa Fe. The Santa Fe formation and overlying younger deposits of probable Pleistocene age occupy a belt 20 miles wide adjoining the east border of this field and are present in outliers within the field

2 Bailey, Vernon, Life zones and crop zones of New Mexico: U. S. Dept. Agr. North American Fauna, nó. 35, p. 9, 1913. 
near the east border. In this field the sediments of the formation are mostly clastic and probably were deposited by streams flowing from mountains to the north. The sediments apparently were deposited in and gradually overlapped the sides of the topographic too little for all of Quaternary time and in addition an indefinite fraction of late Tertiary time. Acsordingly, some uncertainty is introduced regarding the age of the beds overlying the Santa $\mathrm{Fe}$ in this field, and these beds may be as young as Pleistocene.

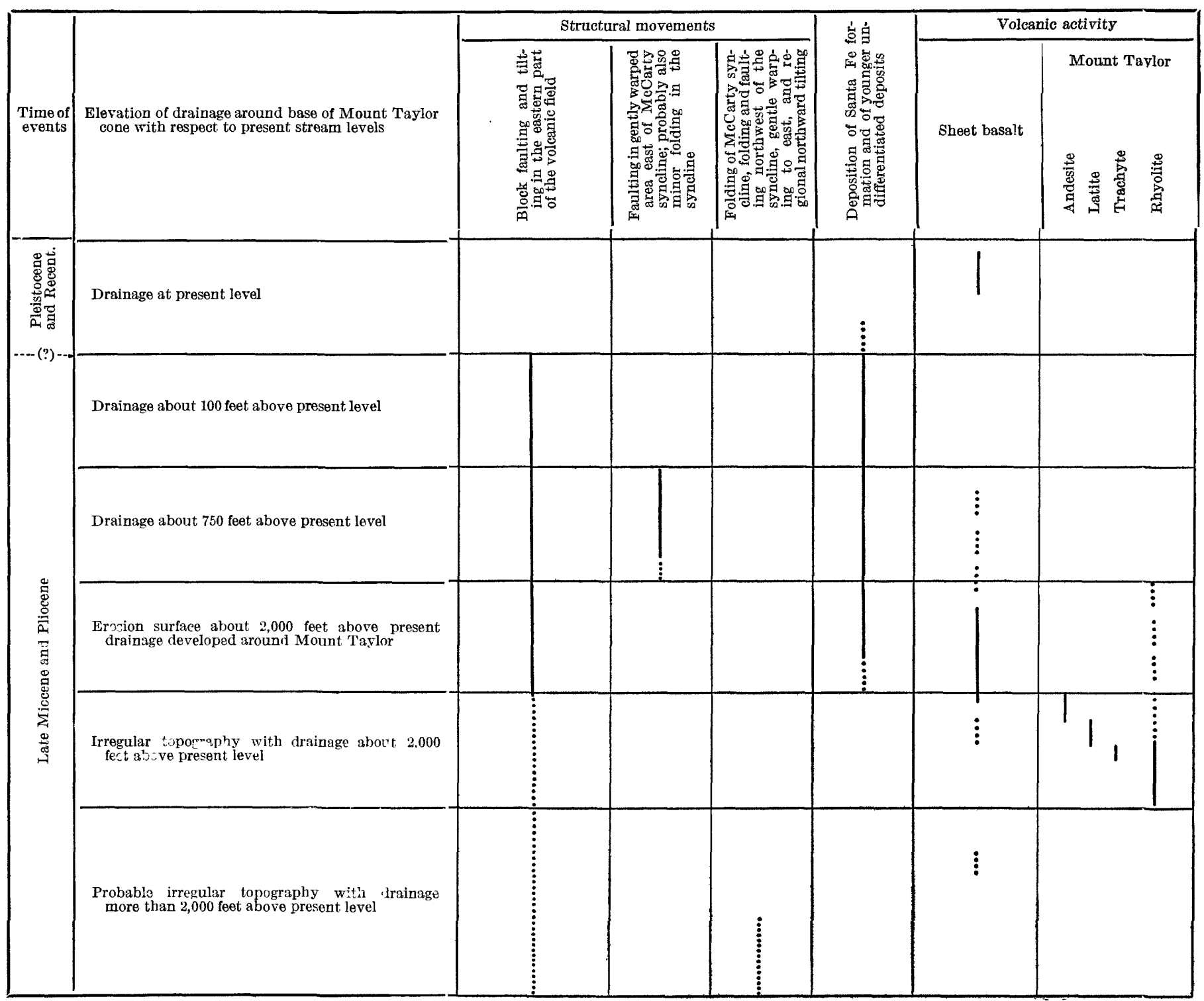

FIGURE 8.-Sequence of late Tertiary and Quaternary events in the Mount Taylor volcanic field. The length of line represents approximately the duration of each a ztivity; solid lines indicate fairly definite information; dotted lines indicate considerable uncertainty. Age assignments are based upon the Santa Fe formation and the Jounger undifferentiated deposits of Pleistocene (?) age.

depression that resulted from the downfaulting of the Rio Grande Valley.

Probably only the upper part of the Santa Fe formation overlaps westward into the Mount Taylor field. Locally, thin deposits lie on pediment surfaces sloping south from the Nacimiento Mountains, and these surfaces are in places only 100 feet above the present drainage level. The possibility must be considered that unless the original thickness was far greater than that of any of the preserved remnants, only slightly more than 100 feet of downcutting has taken place in the region since Santa Fe time. But this is probably

\section{VOLCANIC ACTIVITY GENERAL CHRONOLOGY}

The Mount Taylor volcanic field was the scene of frequent volcanic activity during late Tertiary time, probably beginning in the Miocene epoch, and, with some interruptions, this activity has continued naarly to the present time. The eruptions were preceded by the deformation that uplifted the Zuñi Mountains and Mesa Lucero (fig. 3). In the Mount Taylor field this deformation produced the regional northward dip, the folding of the McCarty syncline, and prol $\rightarrow$ bly most of the other folds and faults associated with that 
syncline. Except for some local basalt flows, the earliest eruptions came from the Mount Taylor volcano, the only large volcano in the field. The volcano erupted first rhyolitic tuff and trachyte, next a series of latites and trachytes, and finally porphyritic andesite. These eruptives accumulated to form the cone of Mount Taylor. The erosion surfaces that were subsequently developed around the cone were flooded with sheets of nonporphyritic basalt and andesite erupted by a large number of vents distributed throughout the volcanic field. A few of these sheets were erupted prior to the latest Mount Taylor eruptions, but most of them were erupted after Mount Taylor had become quiescent. The sheets commonly overlap the edges of the Mount Taylor cone and spread out on the erosion surfaces sloping from it. The maximum eruptions of the sheets occurred prior to the final structural movements in the field, but there were minor basaltic eruptions as late as recent time.

\section{THE MOUNT TAYLOR VOLCANO}

With the possible exception of some very local eruptions of basalt, the Mount Taylor volcano was the earliest and certainly the most active center of volcanism in this area. The volcano still retains its conical form, but its top has been lowered by erosion. (See fig. 9.) The crater probably covered originally an area of less than 1 square mile, but erosion has enlarged it

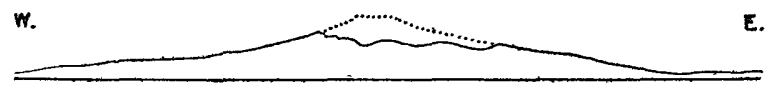

Figure 9.-Hypothetical profile of Mount Taylor showing the probable mass above the present summit that has been removed by erosion.

to an amphitheater covering nearly 5 square miles. (See fig. 10.) Lavas and tuffs accumulated around the old crater until a cone at least 3,000 feet high had been built. There is no way of determining the original extent of these lavas and tuffs, but today they are confined to the cone, whose base has a radius of about 8 miles. (See also p. 65.)

The amphitheater is drained to the east by Water Canyon Creek, which is incised into the east flank of the cone. The rim of the amphitheater is about 2,500 feet above the creek, and the lavas and tuffs erupted from the crater are fairly well exposed along the sides and in the bottom of the amphitheater.

In the eastern part of the amphitheater there is a considerable area of folded sedimentary rocks belonging to the Mesaverde formation. The origmal crater undoubtedly lay west of this outcrop. The lavas in the cone slope in all directions from a point half a mile west of the junction of the North and South Forks of Water Canyon Creek. A system of dikes radiates from the same point, and immediately north of it is the only breccia found in or on the Mount Taylor volcano.

Eruptions from this crater began with vitric tuffs, mostly rhyolitic, and at least one lava flow of porphyritic trachyte, and these were followed by a series of porphyritic latites and trachytes. These early eruptions apparently came from a central crater. The final eruptions of the volcano were porphyritic anc'ssites that were probably supplied mostly by the radiating dikes.

\section{RHYOLITIC 'TUFF}

The earliest definite eruptions (p. 59) from the Mount Taylor volcano were pyroclastic materials that, so far as known, are now entirely vitric rhyolitic tuffs. The tuffs are well exposed in the eastern part of the amphitheater and around the outer fringe of the Mount Taylor cone.

In the amphitheater (fig. 10) east of the folded sedimentary rocks and north of the creek about 400 feet of tuff is exposed. The base is concealed, but it is probable that the underlying rock is Mesaverde sandstone or shale. Most of the tuff is volcanir dust, but there is considerable ash and some lapilli. Both the dust and the coarser material are vitric. No undoubted rock fragments and only a very few crystals, probably feldspar, were observed. The tuff is distimctly bedded, with the coarser material segregated in layer. No evidence indicating flowage was found; the exposure is clearly pyroclastic. The beds in the lowe" part dip about $10^{\circ} \mathrm{E}$. Upward the dip increases, and near the top the beds dip $25^{\circ}$. The obvious suggestion of these dips is that a cone was being built, but two alternatives seem equally possible-(1) an early tuffaceous cone was built around the crater, and later pyroclastic rocks accumulated on the flanks and beyond the limits of the early cone; or (2) as the top of the exposure is about a quarter of a mile north of the base the difference in dip may be due to location and the result of structural movements. The dips are in the same cirection as those of the sedimentary rocks immediately to the west but are less in amount.

Tuff that is probably rhyolitic and compcsed mostly of dust is locally exposed along each side of Water Canyon where the creek is incised into the flanl of Mount Taylor. About midway between the amphitheater and the mouth of the canyon 150 feet of tuff is well exposed beneath the lava that caps the north canyon wall. A short distance upstream from this locality tuff is exposed at a lower altitude in the creek bottom. The total thickness in this part of the canyon is probably at least 200 feet. About half a mile above the canyon mouth, however, the tuff at the lase of the lavas is only 30 feet thick, and near the mouth practically no tuff is present at this horizon. However, there is another 100 feet of tuff above the lowest lava. Nearly all the tuff at these outcrops is of dust size. Locally thin beds of ash consisting of vario's types of glass, much of it black, make dark streaks across the lighter outcrops.

Outcrops similar to those in Water Canyon are found in Lumber Canyon, the next canyon to the southwest. 
Here, as in Water Canyon, rhyolitic tuff lies at the base of the eruptive series and thins from about 100 feet at the head of the canyon to 20 feet at the mouth. Most of the rhyolitic tuff is of dust size and light-colored. The deposit is massive, with lapilli of obsidian and pumice and bombs of pumice scattered irregularly through it. Nonporphyritic andesite, belonging to the post-Mount Taylor sheet eruptives, overlies the tuff and is overlain by another 100 feet of tuff.

A very few feet of rhyolitic tuff, with the base concealed, is exposed beneath the oldest lava along Raton Springs Canyon half a mile north of the south line of tuffs southward from the experiment station is younger than the porphyritic lavas.

About 2,000 feet south of the experiment station the rhyolitic tuff overlies a small basalt flow. Although at several localities basalt preceded the porphyritic andesite lavas from Mount Taylor, this is the only locality found where basalt preceded the rhyolitic tuff. This tuff along the west side of Rinconada Canyon can be traced southward nearly to the south line of T. 11 N., R. $8 \mathrm{~W}$.

Tuff is excellently exposed at several localities in the vicinity of Lobo Canyon, southwest of Mount Tarlor.

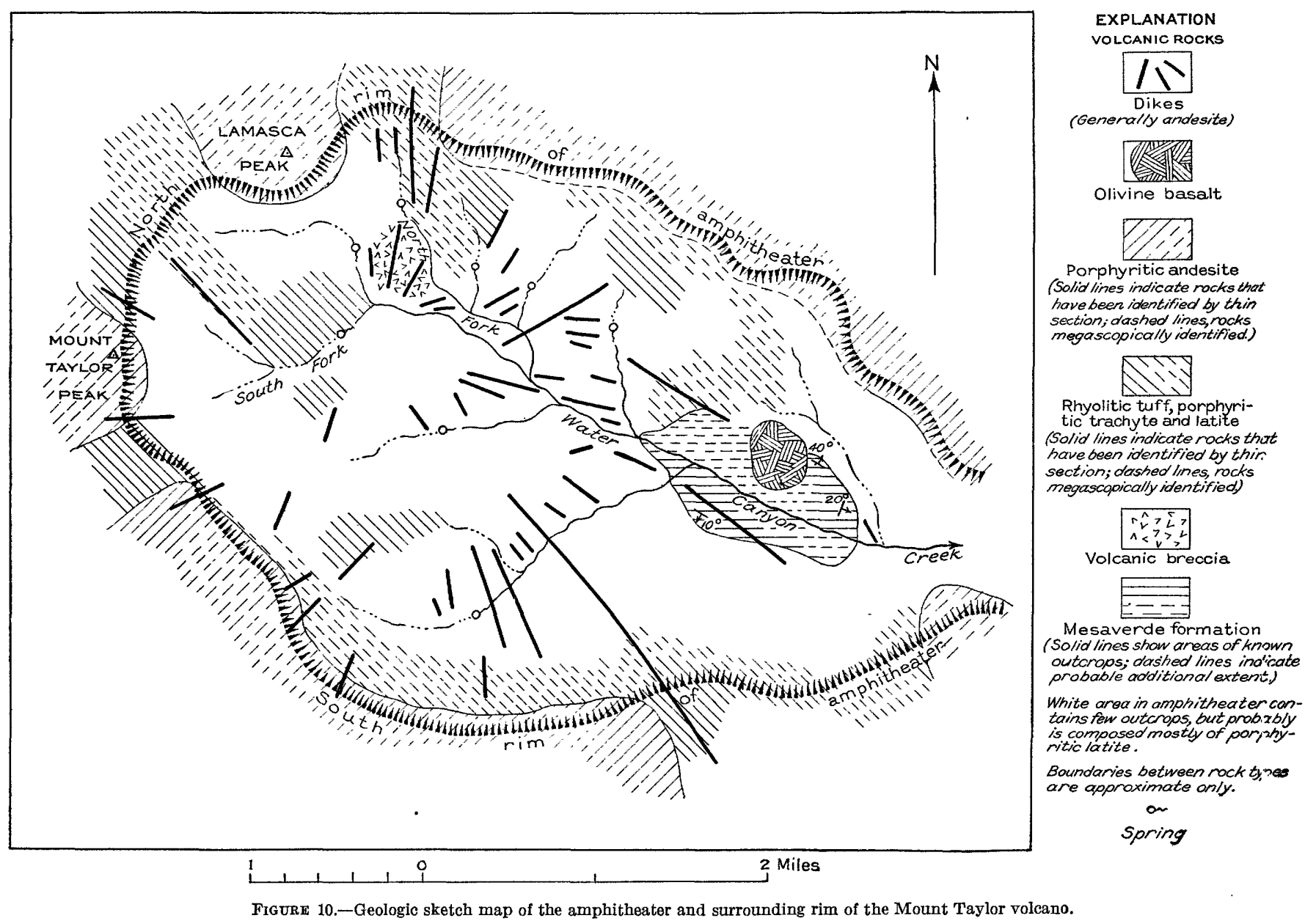

T. 11 N., R. 7 W. It thins out southward, and in the mesa to the south younger eruptives rest directly upon sedimentary rocks.

Along the west side of Rinconada Canyon are several fine exposures of thick bodies of rhyolitic tuff. Near the head of the canyon about 500 feet of tuff is overlain by two or more flows of porphyritic andesite, erupted from Mount Taylor. Although exposures are discontinuous, these flows seem not to extend as far south as the experiment station of the New Mexico Agricultural College. The southward slope of these lavas would carry them below the top of the tuffs just south of the experiment station, so that possibly the upper part of the
Along the south side of La Jara Mesa, west of Mount Taylor, near the west line of T. 12 N., R. 8 W., 200 feet of tuff, probably rhyolitic, is exposed beneath the capping sheet of andesite as shown in the following section:

Section of eruptive rocks on south side of La Jara Mesa

Andesitic lava, apparently a single flow, nonporphyritic; central part massive; top irregular, scoriaceous, and ropy; bottom 1 foot scoriaceous, with vesicles as much as a quarter of an inch in diameter

Agglomerate, red, loosely cemented, angular fragments of scoriacous andesite; fragments small, few of them exceeding a quarter of an inch in diameter. Volcanic dust with a little ash; vitric, white, massive.....- 
Section of eruptive rocks on south side of La Jara Mesa-Continued

Volcanic ash, white, massive, bombs and lapilli as much as 6 inches in diameter irregularly distributed; bombs and lapilli of pumice, gray glass, and black glass; vitric throughout

Tuff, bedded, white; predominantly dust, but ash, lapilli, and bombs sorted in beds.............................

Dust, ash, lapilli, and bombs, white, in part at least rhyolitic; generally massive but locally in irregular beds. Base concealed by talus.

There is probably at least 75 feet of tuff concealed by the talus below the outcrop. The tuff probably rests upon sedimentary rocks, for there is little likelihood that a rock as resistant as lava would be concealed in the steep slope of material so easily eroded. A bomb of pumice from the lowest unit, analyzed by J. G. Fairchild in the chemical laboratory of the Geological Survey, contains $72 \pm 2$ percent of $\mathrm{SiO}_{2}$. The index of refraction of the pumice is $1.495 \pm 0.005$, and the index of the black obsidian is practically the same. The refractive indices of other tuffs examined differ little from this figure, and it is inferred that they are generally rhyolitic.

This deposit thins westward, and probably most of the thinning takes place where the lava truncates the steepest dips in the sedimentary rocks. The exposed tuff is not tilted, like the sedimentary rocks, but lies nearly flat. Just how the thinning takes place was not determined. Only the youngest tuffs are exposed, and the oldest deposits conceivably may be involved in the folding. But the suggestion is clear that these tuffs are later than the deformation of the underlying sedimentary rocks.

About $1 \frac{1}{4}$ miles east of this locality, just east of the cinder cone, tuff is exposed about 300 feet below the base of the lava. It seems likely that the tuff thickens toward the head of the canyon.

Abundant rhyolitic tuff is exposed in the sides of the highest mesa in the Grant Ridges, at the south side of Lobo Canyon. Plate $11, A$, shows rhyolite tuff overlain by sheets of basalt and intruded by a plug that contributed to the sheets. The rhyolite tuff is about 300 feet thick and rests in nearly horizontal position upon tilted sedimentary rocks, although the contact was not found. Plate $11, B$, shows a closer view of the tuff. The material is white, mostly dust, but ash, lapilli, and bombs are sorted in beds. No undoubted fragments of sedimentary rock were found. Most of the bombs consist of frothy pumice drawn out in intimately interwoven thin fibers, but a few are perlitic black obsidian. The tuff was not found beneath the sheet basalt that caps the other mesas of the Grant Ridges, and, though it may be present and concealed by talus, the thickness certainly decreases southwestward. The striking conical form assumed by the sheet eruptives and the complete absence of such structure in the tuff, the thinning of the tuff to the southwest, and the persistence of similar thick tuffs to the north- east toward Mount Taylor indicate with some certainty that their source was the Mount Taylor volceno and not the local vents that supplied the sheet eruptives.

Irregular masses of igneous rock, in part at least of latitic composition, are associated with the tuff at the northeast end of the Grant Ridges. The material is poorly exposed, and no means was found to determine whether it is a lava flow or an intrusior. At one locality horizontal columnar joints truncated by crude plates are exposed for a width of 6 feet, suggesting intrusion of a dike, but similar relations were observed in definite flows on the north flank of Mount Taylor. It was probably some of this material that was collected by J. S. Diller and analyzed by T. M. Chatard in the chemical laboratory of the Geological Surrey. ${ }^{3}$ The analysis showed the following composition:

Analysis of dacite 6 miles northeast of Grart,

\begin{tabular}{|c|c|c|c|c|c|}
\hline $\mathrm{SiO}_{2} \ldots \ldots$ & 49.80 & $\mathrm{Na}_{2} \mathrm{O}$ & 2. 71 & $\mathrm{MnO}_{-}$ & 0.30 \\
\hline $\mathrm{Al}_{2} \mathrm{O}_{3} \ldots$ & 15. 33 & $\mathrm{~K}_{2} \mathrm{O}_{\ldots} \ldots$ & 4. 36 & $\mathrm{CO}_{2-}$ & 2. 56 \\
\hline $\mathrm{FeO}_{\ldots} \ldots$ & 7. 44 & $\mathrm{H}_{2} \mathrm{O}_{-}$ & 1. 38 & & \\
\hline $\mathrm{MgO}_{\ldots} \ldots$ & 6. 61 & $\mathrm{TiO}_{2 \ldots} \ldots$ & 2. 67 & & 101. 08 \\
\hline $\mathrm{CaO}_{\ldots} \ldots$ & 7. 19 & $\mathrm{P}_{2} \mathrm{O}_{5}$ & .73 & & \\
\hline
\end{tabular}

Thin beds of light-colored volcanic dust and ash are locally interbedded with the sheet eruptives on Mesa Chivato. In general these tuffs are less than 10 feet thick. They closely resemble the rhyolitic tuff associated with the Mount Taylor volcano and were probably derived from it.

\section{TRACHYTE}

At the junction of the North and South Forks of Water Canyon Creek (fig. 10) a mass of Forphyritic trachyte lies immediately east of the supposed site of the old crater of the volcano. The mass may be an intrusion that solidified in the eastern part $c^{f}$ the pipe and crater, but it is improbable that such a $p^{1} u g$ should be formed of trachyte and not of latite or andesite, which make up most of the cone. If the trachyte is a lava flow, as seems probable, it is older than the flows and some of the rhyolitic tuff in the northe'st rim of the amphitheater but is probably younger than the earliest rhyolite tuffs. A comparatively smell volume of this early trachyte must have been erupted, for it was found at only the one locality mentioned. It was among the earliest if not the earliest of the lavas, and the fact that it is intermediate in composition between the rhyolite and latite adds interest to its Fosition in the eruptive sequence.

In the hand specimen the trachyte is light gray, speckled with feldspar crystals that are clear except where stained with yellow or red iron oxide. The phenocrysts attain a maximum size of about 3 millimeters. Minute vesicles are uniformly distributed. Crude flow lines, produced by parallelism of the laths

3 Clarke, F. W., Analyses of rocks and minerals from the laborators of the United States Geological Survey, 1880-1908: U. S. Geol. Survey Bull. 419, p. 123, analysis D. 1910. 
of oligoclase, can be seen in thin sections. The trachyte is porphyritic, containing phenocrysts of sanidine and oligoclase. The proportion of sanidine to oligoclase is estimated at about 3 to 1 . A few scattered grains of quartz may be secondary. Magnetite is finely disseminated through the groundmass and in a few phenocrysts. There is only a trace of ferromagnesian minerals.

\section{LATITE SERIES}

The latite series attains a maximum thickness of about 1,000 feet and makes up a considerable part of the Mount Taylor cone. The series includes chiefly latites, but near the top there are at least one local trachyte flow and some andesite. All these lavas are poorly exposed, but a general composite section can be reconstructed from the several outcrops in the amphitheater.

The oldest exposed lava in the latite series crops out near the base of the north rim of the amphitbeater about 2 miles east-northeast of Mount Taylor Peak (fig. 10). The exposure is about 300 feet above the trachyte at the junction of the forks of Water Canyon Creek and about half a mile farther from the crater. The rock is porphyritic. Phenocrysts form about 25 percent of it and consist chiefly of sodic oligoclase with minor quantities of augite and magnetite. The groundmass is microfelsitic and has an index of refraction lower than that of balsam.

Another flow of porphyritic latite, probably slightly higher in the series, is exposed near the base of the rim north of the crater. This rock also has about 25 percent of phenocrysts, mostly corroded crystals of andesine. Orthoclase, augite, magnetite, and highly altered biotite are present in minor amounts as phenocrysts, and there is a little olivine. The groundmass is a feltlike mass of orthoclase and oligoclase in nearly equal amounts and a little magnetite.

The upper part though not the top of the latite series is exposed in the western part of the amphitheater about half a mile east-northeast of Mount Taylor Peak. This outcrop is nearly 1,000 feet higher than the early trachyte and is very near the crater. It is porphyritic latite consisting of about 15 percent of phenocrysts set in a glassy groundmass. Subhedral sodic oligoclase is the most abundant phenocryst, although euhedral biotite is common, and there are a few crystals of anhedral quartz and magnetite. The glassy groundmass has an index of refraction lower than that of balsam. It commonly has a spherulitic structure.

Irregular masses of latite high in the series are exposed on the ridges in the southwestern part of the amphitheater. The percentage of potash feldspar is uncertain, because it rarely occurs as phenocrysts and is nearly indistinguishable in the finely felted groundmass.

The top of the latite series is exposed along the southeastern rim of the amphitheater about $23 / 4$ miles eastsoutheast of Mount Taylor Peak, where it is overlain by porphyritic andesite. The top is about 50 ? feet above the trachyte, and projection of the dips indicates that near the crater the top of the latite series was about 1,000 feet above the trachyte.

These upper lavas of the latite series are porpl yritic and holocrystalline. They contain about 15 percent of phenocrysts, mostly corroded oligoclase. Magnetite and altered biotite are less common. The groundmass consists of euhedral sanidine and oligoclase, the former predominating, and traces of anhedral magnetite. A partial analysis of a lava about 400 feet below the top of the latite series showed $\mathrm{K}_{2} \mathrm{O}, 4.92$ percent; $\mathrm{Na}_{2} \mathrm{O}$, 5.78 percent; and $\mathrm{CaO}, 1.68$ percent.

The top of the latite series is also locally exposed around the flanks of the cone where valleys have been eroded through the later flows of porphyritic andesite. Exposures were found at the localities indicated on plate 7 , but probably there are many others.

Trachyte is exposed along the Forest Service trail half a mile south of Mount Taylor Peak, whers it is probably overlain by porphyritic andesite, although the contact was not found. The rock contains phenocrysts of hypersthene, augite, magnetite, fotash feldspar, and andesine, with the potash feldspar prodominating. The phenocrysts are 3 millimeters in maximum size and make up about 35 percent of the rock. The groundmass is nearly all sanidine, with very minor quantities of oligoclase, augite, and magnetite. The rock is similar in composition to the trachyte at the forks of Water Canyon Creek. The trachyte in the amphitheater, however, lies below the latite series, whereas the trachyte just described is at the top. This is the only locality found where the latite series is known to include trachyte. It is probably a local eruption, because at the other localities examined the top of the series is latite.

In the southeastern part of T. 12 N., R. 8 W., in the canyons 2 miles west of Mount Taylor Peak, a lightcolored lava of vitric latite lies at the top of the series and is overlain by porphyritic andesite. The latite is porphyritic, with phenocrysts of orthoclase, plagioclase (probably oligoclase), and biotite in nearly equal amounts and minor quantities of augite and magnetite. The phenocrysts attain a maximum size of about 3 millimeters and form about 20 percent of the rock. The groundmass is mostly glass but includes some crystalline oligoclase.

The top of the latite series is also exposed in the valleys on the north flank of the cone about $1 \frac{1}{2}$ miles north-northeast of Lamasca Peak. The exposuris are deeply weathered and discolored by hydrous iron oxide. The rock contains about 25 percent of phenocrysts of sodic andesine and biotite in nearly equal amounts and traces of augite and magnetite. The groundmass includes oligoclase and orthoclase in nearly equal amounts. The overlying flows are porphyritic andesite belonging to the succeeding series. 
Irregular masses of latite that are poorly exposed with the tuffs at the northeast end of the Grant Ridges may be flows of this series. They are described on page 60 .

The dike a third of a mile northeast of Mount Taylor Peak trending nearly northwest for half a mile is the only dike in this area known to be latitic. It intrudes the latite series within the amphitheater but was not found to cut the rim or outer flank of the cone. The dike may have supplied some of the later lavas in the latite series. It is porphyritic, with phenocrysts of sanidine, oligoclase, and biotite in nearly equal amounts and a little magnetite. The phenocrysts attain a maximum size of about 3 millimeters and constitute about 20 percent of the rock. The groundmass is a felt of oligoclase, sanidine, and glass in nearly equal amounts.

Another dike, probably latitic, less than a mile south of east of Mount Taylor Peak, trends slightly east of north. It intrudes the latite series and may have supplied some of the later flows in that series. The rock includes about 40 percent of phenocrysts, about half of which are oligoclase, potash feldspar, and perthite in nearly equal amounts. Biotite constitutes about a quarter of the phenocrysts, and the remainder are quartz, hornblende, and magnetite in nearly equal amounts. The groundmass consists of glass and a felt of oligoclase and potash feldspar.

Several rock samples were collected by J. S. Diller from the east side of Mount Taylor, presumably from the latite series in Water Canyon or the amphitheater. Analyses of the samples were made T. M. Chatard in the chemical laboratory of the Geological Survey and showed the following composition: ${ }^{4}$

Analyses of rocks from east side of Mount Taylor

\begin{tabular}{|c|c|c|c|}
\hline & $\mathbf{A}$ & B & C \\
\hline $\begin{array}{l}\mathrm{SiO}_{2} \\
\mathrm{Al}_{2} \mathrm{O}_{32} \\
\mathrm{Fe}_{2} \mathrm{O}_{3} \\
\mathrm{FeO} \mathrm{O} \\
\mathrm{MgO} \mathrm{O} \\
\mathrm{CaO} \mathrm{Na}_{2} \mathrm{O} \\
\mathrm{K}_{2} \mathrm{O} \\
\mathrm{H}_{2} \mathrm{O}\end{array}$ & $\begin{array}{r}68.40 \\
17.99 \\
2.66 \\
1.63 \\
.49 \\
.67 \\
4.54 \\
3.54 \\
.52 \\
-21\end{array}$ & $\begin{array}{r}65.51 \\
16.89 \\
1.41 \\
2.52 \\
.39 \\
1.19 \\
6.42 \\
5.02 \\
.16 \\
.92 \\
.07 \\
.31\end{array}$ & $\begin{array}{r}\text { 65. } 78 \\
\text { 17. } 32 \\
\text { 3. } 68 \\
.46 \\
\text {. } 47 \\
\text { 1. } 66 \\
\text { 5. } 23 \\
\text { 4. } 64 \\
.14 \\
.27 \\
.13 \\
.32\end{array}$ \\
\hline & 100.65 & 100.81 & 100. 10 \\
\hline
\end{tabular}

A. Lava, canyon on east side of San Mateo Mountain.

B. Andesite, canyon on east side of San Mateo Mountain.

C. Quartz latite, canyon east side of San Mateo Mountain.

PORPHYRITIC ANDESITE SERIES

Probably all the eruptives described above, except possibly the latest flows, were poured out from the central vent. The final series of eruptions of the Mount Taylor volcano consisted chiefly of porphyritic

- Clarke, F. W., Analyses of rocks and minerals from the laboratory of the United States Geological Survey; 1880-1908: U. S. Geol. Survey Bull. 419, p. 123, 1910. andesite and were probably supplied mostly by the dikes that radiate from the crater and pipe below. Four lines of evidence indicate this derivetion. (1) With only a few exceptions the dikes are forphyritic andesite identical in composition with the bulk of the final series of eruptives; (2) no dikes were found to intrude the latest flows, although a more complete survey may reveal some; (3) what is believed to be the crater consists only of breccia, and no central core of porphyritic andesite was found; (4) it is very improbable that so many dikes would be intruded so near the surface without reaching the surface and erupting.

The dikes are distributed radially within the amphitheater of the volcano (fig. 10). They are more resistant to erosion than the other rocks in the amphitheater and stand up as high walls, the highest estimated at 100 feet.

Most of the dikes are 20 to 30 feet in wilth, but a maximum of 60 feet was observed. Within the amphitheater the contact between the dikes and the early series of eruptives is generally sharp and merked by a thin zone of platy jointing and more or less black perlitic glass. Around the rim, however, particularly in the southwestern part, where the dikes are in contact with the latest series of eruptives, the contacts are commonly very indistinct, and locally the jointed structure of the flow and that of the dike grade into each other. Horizontal columnar joints are well developed in all the dikes observed. So far as could be determined the dikes stand vertical or nearly so.

Fifty dikes were found and mapped, and thin sections from 14 were examined. The easternmost dike in the amphitheater, just north of Water Canyon Creek east of the Mesaverde outcrop, is probably related to the later sheet eruptives and is not described bore. Two latitic dikes have already been described. Eleven of the dikes are very similar in composition, containing phenocrysts of andesine (rarely oligoclase or labradorite), biotite, augite, magnetite, and rare'y olivine. The phenocrysts of augite and magnetite are commonly in nearly equal amounts, but biotite is the predominant mafic mineral. There is generally two or three times as much feldspar as mafic minerals among the phenocrysts. The groundmass commonly consists of more or less glass with tiny laths of oligoclase. Where the oligoclase is anhedral and the groundmass is feltlike there may be some potash feldspar.

Except in the bottoms of some of the largest valleys, flows of the porphyritic andesite series form the surface of most of the flanks of the Mount Taylor cone. This series apparently constitutes a smaller volume of eruptives than the latite series.

One of the thickest accumulations of thes andesitic lavas is along the south rim of the amphitheater, 2 miles southeast of Mount Taylor Peak. The thickness here is estimated at 500 feet and represents several flows, certainly not less than three. Exposures are not 


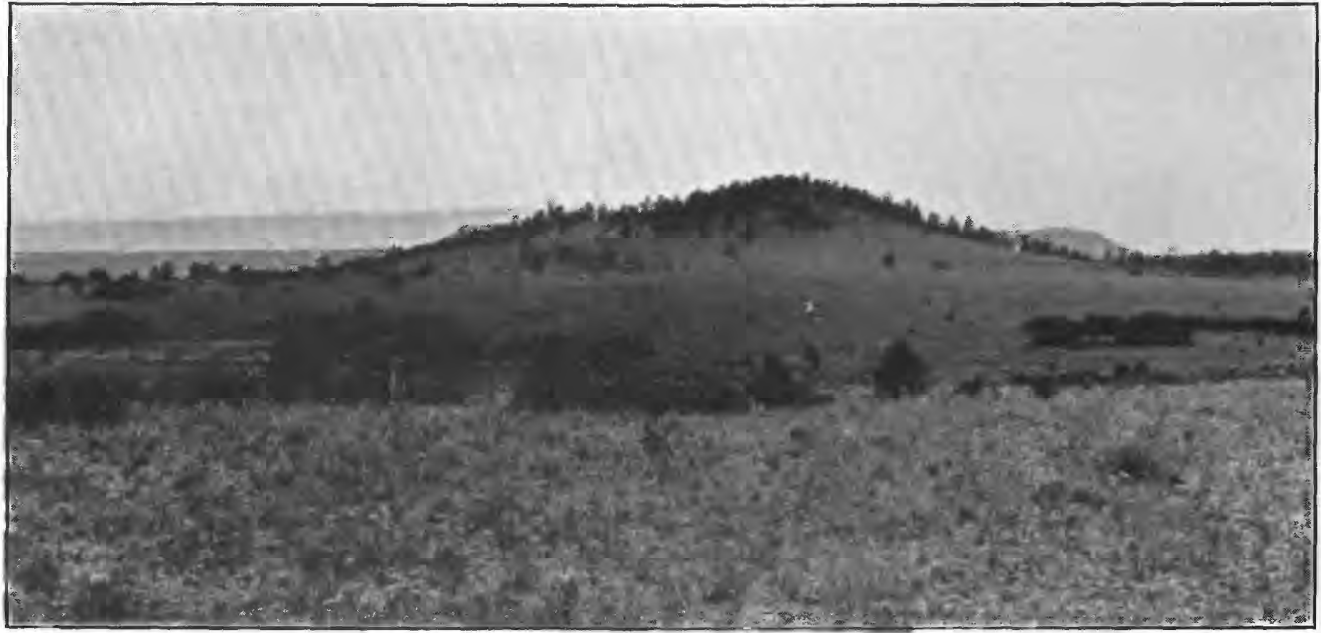

A. BASALTIC LAVA AND CINDER CONE ON THE SHEET BASALT CAPPING HORACE MESA. View in center of sec. 3, T. 11 N., R. 8 W.

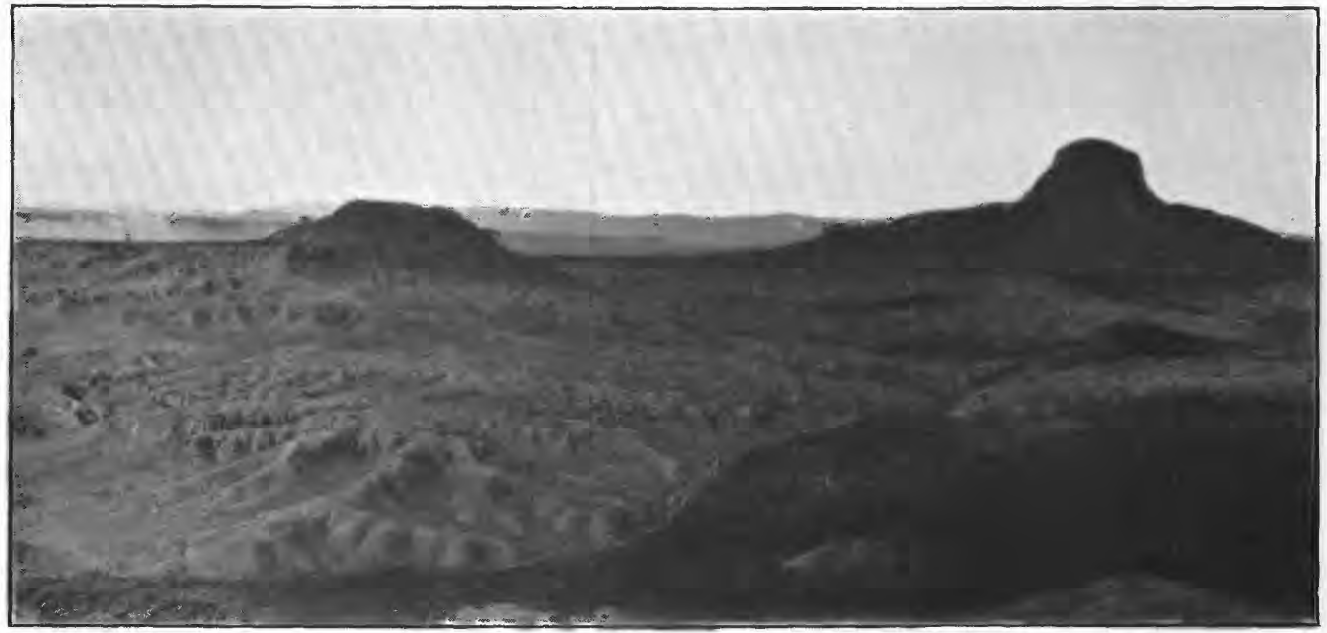

B. VIEW LOOKING NORTHEAST FROM TOP OF VOICANIC NECK EAST OF LA ABRA DE LOS CERROS.

Cabezon Peak (right) is composed almost wholly of basalt. Cerro Chato (left) is mostly basaltic breccia. Road in foreground serves as scale for nearby buttes of Cretaceous shale.

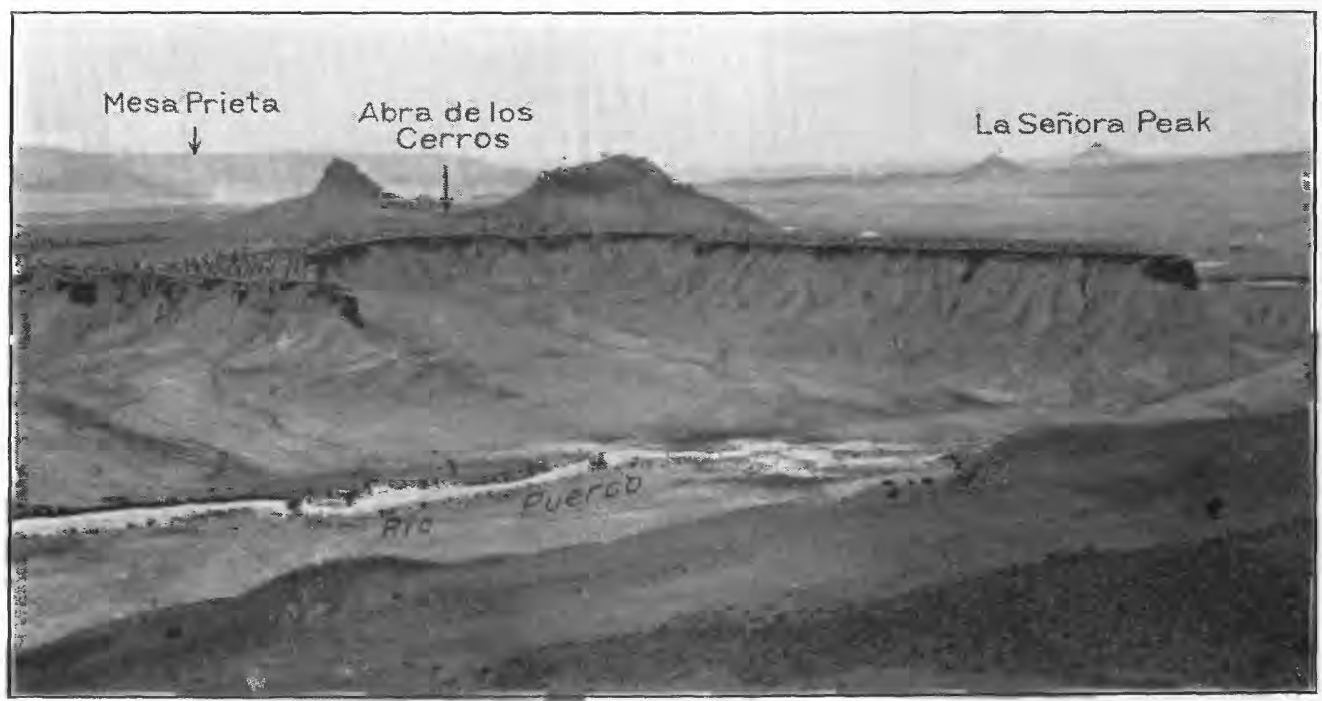

C. VIEW LOOKING SOUTH FROM CERRO DE LOS CUATES.

The mesa across the Rio Puerco is capped with Cretaceous sandstone. 


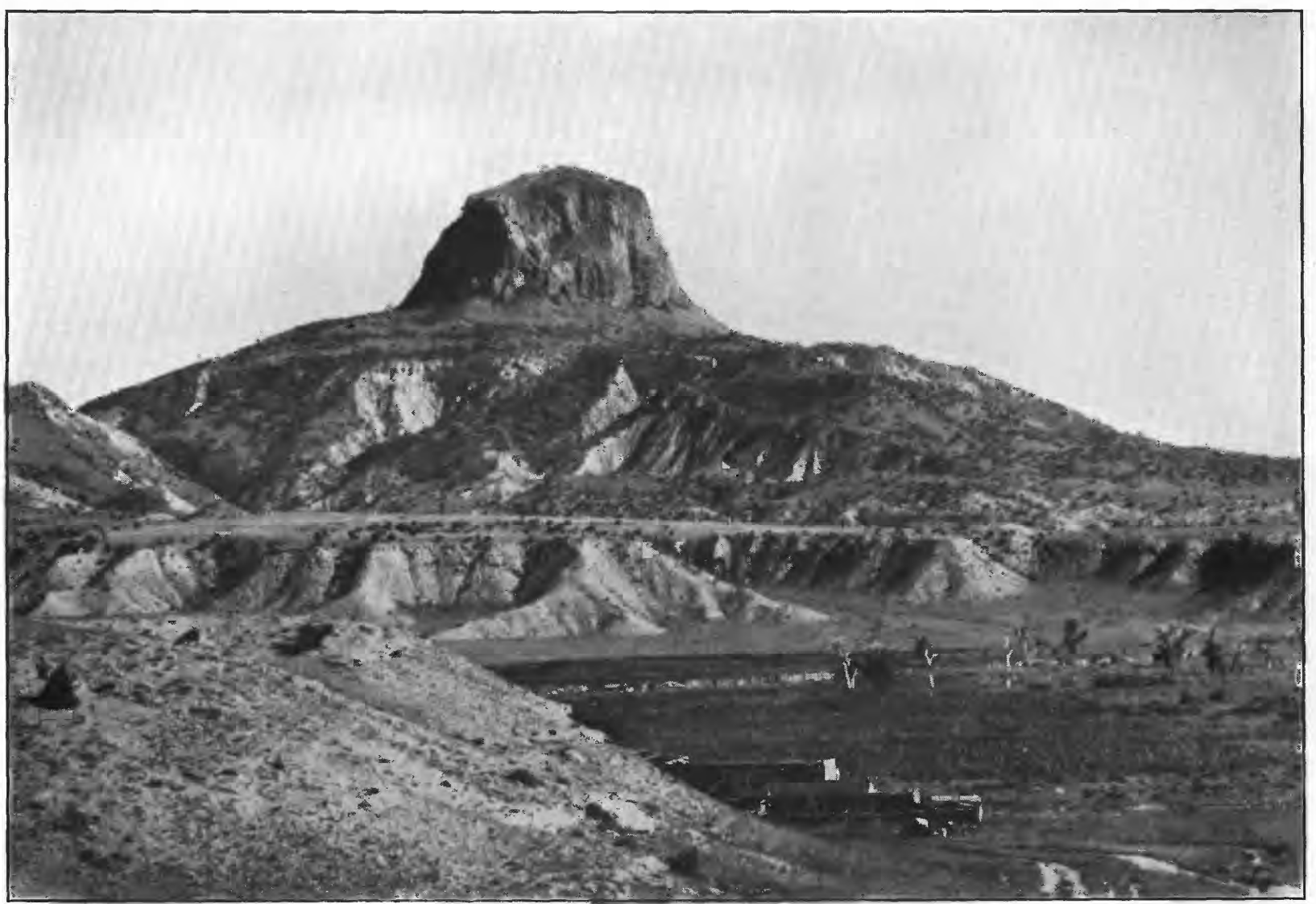

A. CABEZON PEAK VIEWED FROM THE BLUFFS ABOVE THE VILLAGE OF CABEZON.

The peak is a volcanic neck of basalt jointed in nearly vertical columns but capped with highly scoriaceous basalt. Photograph by W. T. Lee.

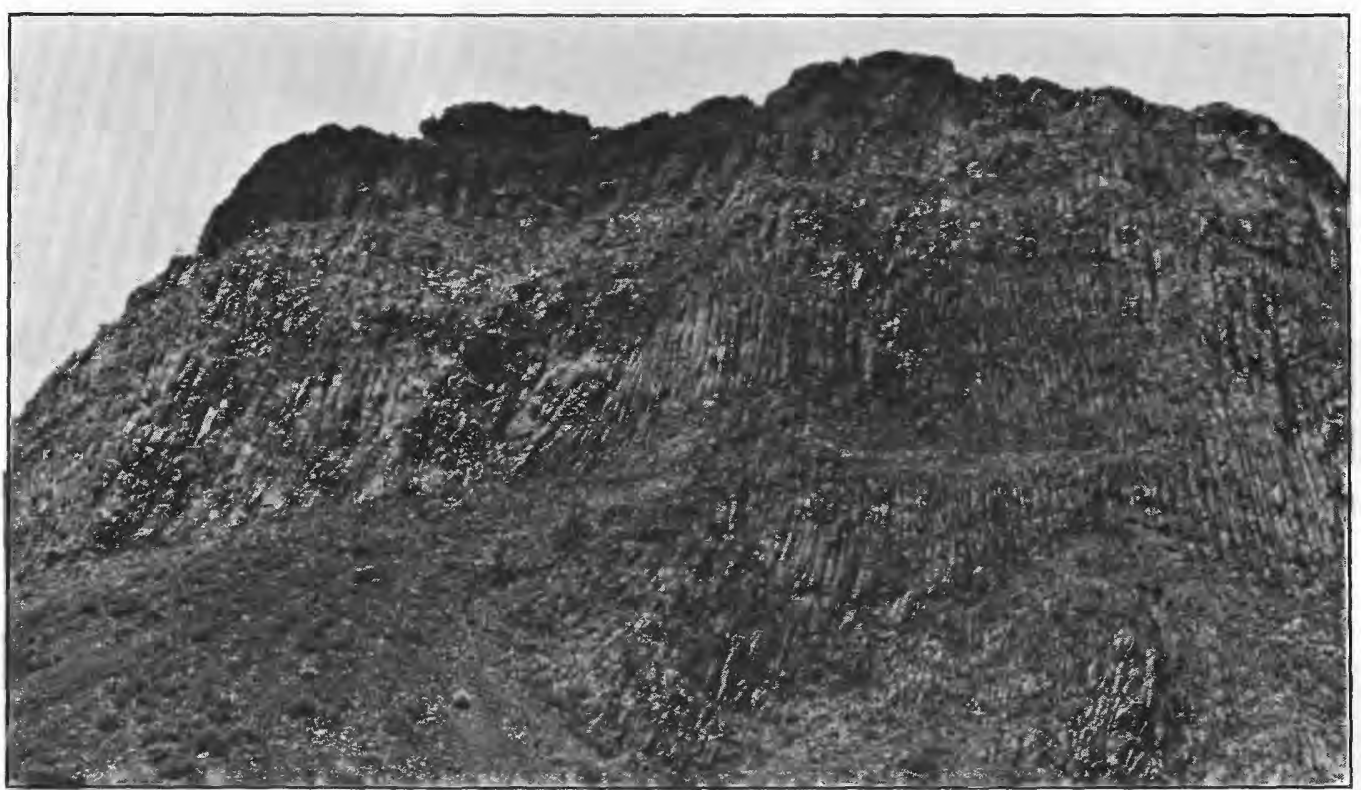

B. CLOSER VIEW OF SOUTH SIDE OF CABEZON PEAK.

Showing fairly uniform vertical columns capped with a layer of scoriaceous basalt at the top of the neck. 
sufficiently good to determine with certainty the limits of individual flows. They rest upon porphyritic latite of the preceding series. Thin sections of three flows show very similar compesition. Each includes about 35 percent of phenocrysts, mostly of andesine but with minor amounts of augite and magnetite. One rock has a few olivine phenocrysts. The groundmass is practically all tiny laths of oligoclase with a little glass. A sample of the highest flow was analyzed for alkali content by E. T. Erickson in the chemical laboratory of the Geological Survey, with the following result: $\mathrm{K}_{2} \mathrm{O}$, 3.42 percent; $\mathrm{Na}_{2} \mathrm{O}, 5.62$ percent; $\mathrm{CaO}, 4.00$ percent.

Half a mile southeast of Mount Taylor Peak andesite is exposed above the latite series. The contact with the trachyte, here the top of the latite series (p. 61), was not found. At least two flows are present. The lower one is nonporphyritic and estimated to include about 75 percent of oligoclase, 20 percent of glass, and 5 percent of magnetite. There are few crystals of ferromagnesian minerals. Some crystals of oligoclase are fairly large, but there is complete gradation from these to microcrystalline size. The younger andesite is distinctly porphyritic, with about 15 percent of phenocrysts, mostly of sodic andesine and minor quantities of augite and only traces of magnetite. Most of the rock consists of tiny laths of oligoclase in dark glass.

Mount Taylor Peak, at the west rim of the amphitheater, is capped with similar porphyritic andesite. Probably the flows were once connected but have been separated by erosion.

A valley north of Mount Taylor Peak exposes the top of the latite series. Lamasca Peak, next to the northeast, is capped by flows which megascopically resemble the porphyritic andesite series.

Another valley at the rim east of Lamasca Peak exposes lavas that are probably latitic and may be connected with the exposed top of the latite series $1 \frac{1}{2}$ miles north-northeast of Lamasca Peak (p. 61). Porphyritic andesite caps the ridge east of the valley and covers most of the north and east sides of the cone, but the latite may be exposed in the deeper canyons in the part of the cone mapped as porphyritic andesite. Three thin sections from these flows indicate little variation in the lithology. The rocks are porphyritic, and most of the phenocrysts are andesine, but there are minor quantities of augite and magnetite and traces of hypersthene and biotite. The groundmass makes up about 65 percent of the rock and consists of felted feldspar and glass. Oligoclase can ordinarily be recognized in the groundmass, but considerable potash feldspar is probably occult in the glass.

Much later sheets of basalt and andesite from extraneous sources overlap the edges of the cone on the north, east, and west sides. There are similar overlaps along the south side, but the numerous canyons there provide opportunity for examining the outer fringe of flows from Mount Taylor.

150009-38-3 -2
Along the west side of Rinconada Canyon the porphyritic andesites are overlapped by the sheet eruptives. (See pl. 7.) At the head of the canyon the porphritic andesite series consists of two flows resting upon rhyolitic tuffs. The lower flow, about 100 feet thick, has very irregular columnar jointing and is not marledly scoriaceous. It contains only a few large corroded phenocrysts of calcic andesine set in a felted groundmass of feldspar and glass. There is little magretite or ferromagnesian mineral. The material has a distinct flow strueture. The upper flow is highly scoriaceous and about 40 feet thick. It is abundantly porphyritic, with many euhedral phenocrysts of calcic andesine and minor quantities of olivine, augite, and magnetite; in a groundmass of dark glass. There is only a very slight suggestion of flow structure.

Porphyritic andesite, interpreted as derived from Mount Taylor, is exposed beneath later sheet eruptives in Raton Springs Canyon. The rock approaches a basalt, having phenocrysts of labradorite, but the groundmass is a less calcic plagioclase. Olivine and augite are subordinate as phenocrysts; augite and magnetite are common in the groundmass.

Where Lumber Canyon and Water Canyon cut the southeast fringe of the Mount Taylor cone the apparent order of eruptives is reversed. Porphyritic andesite, believed to have been erupted from Mount Taylor, overlies nonporphyritic andesite that may have come from the plug of similar andesite in the eastern part of the amphitheater. The nonporphyritic andesite is probably related to the generally later sheet eruptives. The porphyritic andesite contains phenocrysts, chiefly of calcic andesine, with traces of olivine, augite, and magnetite. The groundmass is mostly calcic oligoslase with minor and nearly equal quantities of augite, olivine, and magnetite.

\section{SUMMARY OF MOUNT TAYLOR ERUPTIONS}

The eruptions of the Mount Taylor volcano bagan probably in late Miocene time, subsequent to the major movements of folding and faulting in the central and: western part of the volcanic field. (See fig. 8 i) The volcano broke out in the deepest part of the McCarty syncline, which was the center of maximum intensity of the early folding. Inasmuch as both the volcano and the fold are unusual features of the southern San Juan Basin, their association seems to indicate more than fortuitous coincidence. The volcanic activity followed the major structural movements, but the time interval is not known. It is interesting, though purely speculative, to consider the possibility that the structural movements and fusion of the deep-seated magma were contemporaneous and related, and that the time interval between the structural movements and surface eruptions was that required for the lava to find its way to the surface. 
The eruptions occurred in a fairly well defined sequence of composition. The earliest eruptiuns were more or less violent ejections of rhyolitic tuffs. Next followed relatively quiet eruptions of porphyritic lavas that are separable into two and possibly three series on the basis of their content of potash feldspar. The porphyritic trachyte, interpreted as a flow (p. 60), probably followed much of the rhyolitic tuff but has only a small volume. This was followed by a large volume of porphyritic latite - interrupted, however, by at least one more flow of porphyritic trachyte. The latite in turn was followed by a slightly smaller volume of porphyritic andesite. The following table gives estimates of the relative volumes of these materials:

Estimated volume of Mount Taylor eruptives

\begin{tabular}{|c|c|c|c|}
\hline Rock series & $\begin{array}{c}\text { Maximum } \\
\text { observed } \\
\text { thickness } \\
\text { (feet) }\end{array}$ & $\begin{array}{c}\text { Minimum } \\
\text { area cov- } \\
\text { ered (square } \\
\text { miles) }\end{array}$ & $\begin{array}{c}\text { Estimated } \\
\text { volume } \\
\text { (cubic } \\
\text { miles) }\end{array}$ \\
\hline $\begin{array}{l}\text { Rhyolitic tuff } \\
\text { Trachyte } \\
\text { Latite series } \\
\text { Porphyritic andesite series }\end{array}$ & $\begin{array}{c}500 \\
(?) \\
1,000 \\
500\end{array}$ & ${ }^{60^{-1}}{ }^{155}$ & $\begin{array}{l}\text { 5. } 1 \\
.05 ? \\
\text { 4. } 0 \\
\text { 3. } 6\end{array}$ \\
\hline
\end{tabular}

The figures indicate that a minimum total volume of about $12 \frac{1}{2}$ cubic miles of lava and tuff was erupted from the Mount Taylor volcano, a volume sufficient to provide a 6 -inch blanket over the entire State of New Mexico.

Probably the rhyolite and trachyte and most of the latite were erupted from the central crater, whereas most of the porphyritic andesite and possibly the youngest latite were erupted by dikes intruded radially around the main pipe. The eruptives now make a cone 3,000 feet high with a base covering about 150 square miles. The cone is what is left of the volcano after prolonged erosion has accomplished about 2,000 feet of valley cutting in the surrounding country. Certainly the original volcano was higher and probably covered a larger area than the preserved remnant. Figure 9 shows the probable minimum amount of erosion that has altered the cone. The figure indicates .i lowering of the top by nearly 1,000 feet but does not consider the possibility of lowering of the flanks. During this period of erosion successive pediments, or erosion surfaces, were developed around the cone. It was mostly on these surfaces that the sheet basalts were erupted, and these later lavas have proved so resistant to erosion that several of the old surfaces are still preserved under the lava capping.

\section{SHEET BASALT}

Some of the sheet eruptives preceded the latest flows from Mount Taylor, but most of them were poured out after Mount Taylor had become quiescent. The sheets spread out on erosion surfaces developed around the base of the Mount Taylor cone, and most of them were erupted from central vents, though a few came from fissures. Where the sheets are still preserved as the caps of masas the vents are marked by conical piles of lava and cinders as much as 500 feet high. (See pl. 12, $A$.) Where erosion has removed the lava cap and lowered the country rock the vents are marked by picturesque necks, columns of lava and breccia that solidified in the pipes without reaching the surface. (See pls. $12, B, C ; 13, A ; 16, A$.) Locally a relief as great as 1,800 feet has been produced around lava necks. The breccia necks (pl. 12, $B$ ) are less resistant and topographically are not so prominent. Several of the necks are elongate and dikelike; others are apparently cylindrical.

Johnson ${ }^{5}$ showed conclusively that the ir terpretation of the necks as such is inescapable. Vertical contacts with platy jointing can commonly be found. In addition, erosion has produced all gradations from the lava cones, with the lava sheets completely around the vents (pl. 12, $A$ ), through cones with the lava removed from only one side, exposing the pipe (pl. 11, $A$ ), to necks from which the surrounding sheets of lava have been completely removed (pls. $12, B, C ; 13, A ; 15, A ; 16, A$ ).

Most of the vents are northeast of Mount Taylor, but a few are scattered around the south and west sides. The old cone is nearly surrounded by the sheets, which, on all sides except the southeast, overlap the earlier porphyritic lavas from Mount Taylor. Some of the lava sheets broke out from vents on the flanks of the Mount Taylor volcano, adding their lavas to the cone.

Numerous dikes were intruded at the time of the sheet eruptions. Most of them trend east of north, nearly parallel to the strike of the faults in the eastern part of the volcanic field and to the strike of one set of faults in the central and western parts. However, only one dike was definitely intruded along a fault surface. The necks of dikelike form generally trend east of north, but no systematic distribution of these necks was determined. The alinement of Sleeping Hound Butte, Juan Tafoya Peak, and Santa Rosa Peal is obvious, but the trend of this alinement is nearly north-south, inclined $15^{\circ}-20^{\circ}$ to other regional trends. Detailed mapping of the cones on Mesa Chivato might provide the clue for determining a system to the lonation of the volcanoes, for the vents there are more closely spaced than elsewhere.

The basaltic lavas erupted by these volcanoes flowed as sheets. They generally contain a very few phenocrysts, mostly olivine. The feldspar in the lavas is generally either calcic andesine or sodic labradorite, and, depending upon which predominates, the individual flows are designated respectively andesite or basalt. There is commonly a glassy groundmass, lowever, and the feldspar of this groundmass is presumably less calcic than the larger, determinable crystals. More

Johnson, D. W., Volcanic necks of the Mount Taylor regicn, N. Mex.: Geol. Soc. America Bull., vol. 18, pp. 303-321, 1907. 
comprehensive studies, therefore, may provè that the basaltic type is less abundant than is indicated in this report. This lava series is loosely designated basaltic to avoid confusing it with the porphyritic andesite series erupted by Mount Taylor. Tremendous quantities of basaltic breccia in the pipes and in some of the dikes consist of fragments of basalt and sedimentary rocks in a friable glassy matrix. Apparently very little of the breccia was extruded. A few thin beds of tuff, probably rhyolitic, are interbedded with some of the lava sheets on Mesa Chivato. This tuff may have been a result of minor explosions of the Mount Taylor volcano near the end of its activity.

\section{BASALT IN THE AMPHTHEATER}

In the eastern part of the amphitheater (fig. 10) a mass of basalt intrudes folded sedimentary rocks. The intrusion is bordered on three sides by platy joints, but near the top the central core consists of highly scoriaceous basalt. The dip of the platy jointing converges upward, suggesting that the intrusion narrowed upward, but study of jointing in the necks northeast of Mount Taylor discounts this evidence. For example, the zone of platy jointing on the north side of the intrusive mass dips $55^{\circ} \mathrm{N}$., but it may have developed by consolidation of the basalt against earlier intrusives, as basaltic breccia. Such relations are common in many of the necks, and so the jointing cannot be regarded as necessarily indicative of the limits and shape of the whole intrusion.

Whether or not the intrusion domed the sediments cannot be determined. Elsewhere in this field the intrusion of these basaltic rocks did not deform the country rock.

The intrusive mass is olivine basalt in which small phenocrysts of olivine and augite form about 10 percent of the rock. Augite but not olivine is present in the groundmass, which contains also about three times as much labradorite as augite and minor quantities of magnetite.

This intrusion may mark the source of some of the olivine andesite sheets that underlie the latest porphyritic andesite on the southeast flank of Mount Taylor (p. 63). But the careful tracing of individual flows necessary to decide this point was not attempted during this study.

\section{VENTS ON THE NORTH FLANK OF MOUNT TAYLOR}

Eruptions broke out from several vents on the northeast flank of the Mount Taylor cone. Basaltic lava and cinder cones were built upon the earlier porphyritic andesite flows of the volcano, and tongues of basalt were poured northward down the slope. These eruptives are younger than the porphyritic andesites, but their age relative to the sheets on Mesa Chivato is not known. At least 300 feet of lava from these vents accumulated locally on the lower flanks of Mount Tay- lor. Just southwest of the Fernandez camp there are probably six or seven flows. These lavas thin vrestward (and probably eastward), and in two canyons the underlying porphyritic andesite is exposed.

These basaltic lavas are all dark gray and dense. The more scoriaceous portions of the flows weather red, apparently because of oxidation of the abundant magnetite. There are a few large phenocrysts of olivine, the only megascopic mineral in the flows. The rocks consist of sodic labradorite or calcic andesine, olirine, augite, and magnetite, with more or less glass. The plagioclase generally forms more than 50 percent of the rock, and olivine is generally the most common mafic mineral. Magnetite ranges from a trace to about 10 percent.

\section{FLOWS ON MESA CHIVATO}

Mesa Chivato is a part of the highest and no doubt oldest pediment developed around the Mount Taylor cone, and many small volcanoes flooded it with sheet basalt. Probably these eruptions occurred soon sfter the pediment was formed, because the smooth surface beveling resistant sandstone and easily eroded shale would not otherwise be preserved.

No detailed work was done over most of the interior of Mesa Chivato, and neither the number nor the exact location of the volcanoes is known. About 50 cones were counted in a view from the north flank of Mount Taylor. They seem more or less clustered, with broad lava flats separating them. Each of the few cones examined is composed of basaltic lava and cinders of scoria. No craters were found.

Some vitric and some lithic tuffs commonly underlie the basaltic sheets, and locally pumiceous tuff is irterbedded with the flows. The source of the tuffs is not known. The lithic tuffs were probably erupted by the vents that supplied the basaltic sheets, for lapilli of scoriaceous basalt are common, and such material was not erupted by the Mount Taylor volcano. However, the pumice is apparently rhyolitic and would represent a separate, extreme differentiate if erupted by these vents. It may have been thrown out during the final stages of the Mount Taylor volcano or may have an extraneous source.

These sheet eruptives include both andesite and basalt. At Garter Mesa, 21\% miles southeast of Marquez, the lava is andesitic, being composed roughly of 40 percent of calcic andesine, 10 percent of olivine, 10 percent of augite, 5 percent of magnetite, and 30 percent of glass. There are a few large phenocrysts of olivine. At the southeast corner of Mesa Chivato, 41/2 miles east of Picacho Peak, are two basaltic flows. Both have distinct amygdules coated vith zeolites. The lower flow is composed roughly of 65 percent of labradorite, 15 percent of olivine, treces of magnetite, and glass. The upper flow is compcsed roughly of 50 percent of sodic labradorite, 5 percent of 
magnetite, and a feltlike mass of glass and tiny anhedral crystals of mafic minerals.

Andesite occurs in the lower part of Canyon Colorado, near the north base of the Mount Taylor cone. The flow apparently came from a cone just west of the creek. The flows slope $5^{\circ} \mathrm{S}$. on the south side of the cone and extend a few hundred feet up the creek, overlapping the eroded flows of porphyritic andesite. To the north, the flows slope nearly $12^{\circ}$ near the cone but flatten downstream and extend onto Mesa Chivato. The flows are andesitic, dark gray, and nonporphyritic. The composition is roughly 75 percent of calcic andesine, 10 percent of olivine, 10 percent of augite, and 5 percent of magnetite.

Erosion around the edges of Mesa Chivato has locally exposed the roots of cinder cones and has therefore produced natural cross sections of these volcanoes. At one of these, near the head of Marquez Canyon, the exposure shows an inner core of dense basalt locally chilled against an outer zone of basaltic breccia. The plug is 800 to 1,000 feet in diameter, and the exposed section is about 600 feet high. It intruded thick sandstone and shale of the Mesaverde formation, built a cone on the high surface of the mesa, and contributed to the lavas on that surface. Undisturbed and unaltered sandstone of the Mesaverde is exposed 30 feet from the breccia, but the contact is concealed. The dense central core grades upward to scoriaceous and even ropy basaltic lavas that cap the mesa. The scoriaceous parts of the outcrop are commonly weathered to brick red, but the dense portion is deep gray. The core is jointed in columns that, near the base of the exposure, dip $30^{\circ}$ toward the outer contact. Upward the columns are masked, but to judge from other localities they probably assume a nearly vertical position. The columnar jointing gives way to platy jointing at 3 to 5 inches in from the contact with basaltic breccia. The contact between the platy-jointed basalt and the breccia is sharp but is crenulated for a width of $2 \frac{1}{2}$ inches, whereas the boundary between the platy jointing and the columnar jointing is regular and does not follow these crenulations. The breccia consists of an irregular assemblage of ropy, scoriaceous basalt, dense basalt, and boulders of sedimentary rock in an extremely friable glassy matrix. Boulders of sandstone are also present in the core cf the plug, but they are less abundant toward the center and top.

\section{LA JARA MESA}

The pediment north of Mount Taylor was probably continuous around the west side of the mountain and across La Jara Mesa. Near Mount Taylor the pediment is cut across rhyolitic tuffs and porphyritic andesite erupted by Mount Taylor, but to the west the surface truncates folded sedimentary rocks. Four vents in the southern part of the mesa supplied most of the basaltic lava cap. These lavas spread out in sheets, flowed against the erosion scarp developed at the west edge of the Mount Taylor cone, and entered some of the valleys eroded in its flanks. In the eastern part of the mesa the sheets probably overlap porphyritic andesite erupted by Mount Taylor. Elsewhere they rest upon the rhyolitic tuff, except in the western part of the mesa, where they cover the truncated edges of the folded sedimentary rocks.

In the southern part of the mesa, near the west line of T. 12 N., R. 8 W., the lava is dark-gray hypersthene andesite. The main part of the flows is dense, but the upper part and bottom are highly scoriaceous. The dense portions of the flows are jointed in vertical columns. The thickness of individual flows ranges from about 50 to about 80 feet. The rock is composed of about 40 percent calcic of andesine, 10 percent of hypersthene, 5 percent of magnetite, and 45 percent of cryptocrystalline groundmass.

\section{GRANT RIDGES}

The Grant Ridges are three lava-capped mesas north of Grant and southwest of Lobo Canyor. The lava sheets on these mesas are basaltic, were undoubtedly connected, and may have been continuous with the basaltic lavas that cap Horace Mesa and possibly La Jara Mesa. The lavas on the ridges were supplied by at least four vents on the most northeasterly mesa. One of the vents is located along the southeast side of the mesa and provides one of the most instructive exposures in the volcanic field.

At this exposure erosion has developed a natural cross section of the volcano (pl. 11, $A$ ). J Jere a cylindrical pipe of basalt about 500 feet in diameter intruded the exposed tuffs and erupted onto the erosion surface cut on the tuff. Within the pipe basalt in contact with tuff is jointed in plates to a depth of a few inches. The remainder of the basalt is jointed in vertical columns. These relations are common in the Mount Taylor volcanic field and suggest that cooling in the pipes progresssed downward from the craters rather than horizontally from the contacts. The flat-lying beds of tuff at the locality shown in plate $11, A$, illustrate the general absence of structural deformation accompanying the basalt intrusions in this volcanic field. Some important exceptions, however, are noted in descriptions of other localities. Above the tuff can be seen a cross section of the cone, which is composed of scoria and short flows of basaltic lava. The scoria consists of basaltic boulders, mostly less than a foot in diameter, in a friable glassy matrix. A very few small fragments of sedimentary rocks were found with the scoria. Exceedingly fluid basalt, erupted after the scoria, flowed southwest in sheets less than 100 feet thick for at least 7 miles down a $1 \frac{11}{2}$ percent grade.

At the other vents in the Grant Ridges thin bands of perlitic glass, locally squeezed into minute isoclinal folds, form the contact between the basslt intrusions and the earlier rhyolitic tuff. 
The lava flows are mcstly basalt consisting of about 30 percent of sodic labradorite, 5 to 10 percent of olivine, 10 percent of augite, and 5 percent of magnetite in a cryptocrystalline and glassy groundmass. Some andesite was found which consisted of about 60 percent of calcic andesine, 5 percent of olivine, 5 percent of augite, and 5 percent of magnetite in a cryptocrystalline groundmass.

Several basalt samples were collected by J. S. Diller "6 miles northeast of Grant", 6 presumably from the northeasterly mesa of the Grant Ridges. They were analyzed by T. M. Chatard in the chemical laboratory of the Geological Survey with the following results:

Analyses of basalt from Grant Ridges

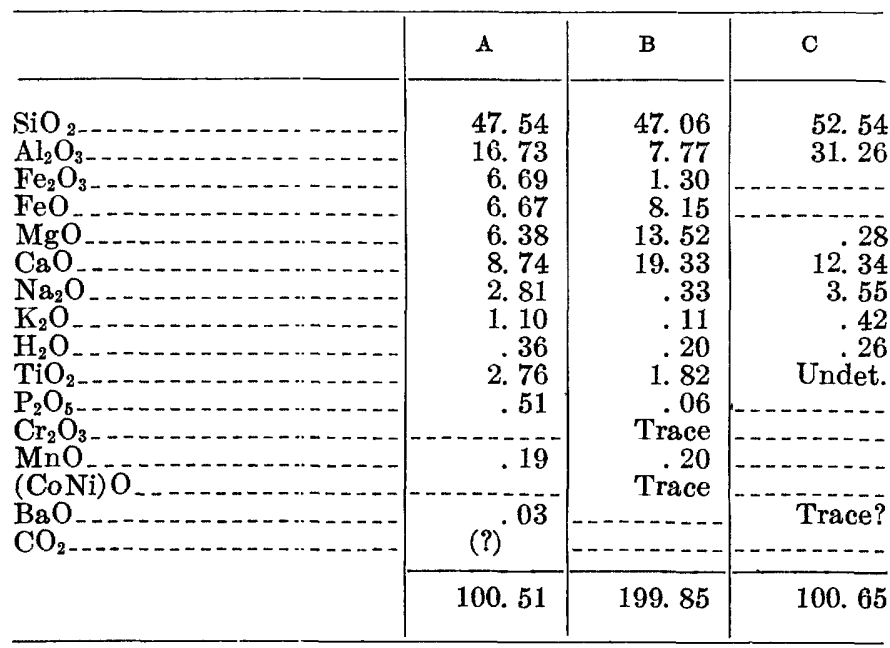

A. Basalt 6 miles northeast of Grant. Contains chiefly plagioclase, augite, and olivine, with much magnetite.

B. Augite from A.

C. Feldspar from A. Analysis on 0.75 gram of material.

\section{HORACE MESA}

The erosion surface beneath the sheet eruptives on Horace Mesa lies at about the same altitude as the surface in Mesa Chivato and La Jara Mesa and was probably originally a connected part of that surface. Where remote from the Mount Taylor cone the surface slopes about 50 feet to the mile away from the cone, but the gradient increases toward the cone. The surface is cut across the outer fringe of tuffs and porphy. ritic lavas erupted by Mount Taylor, but to the soutb it truncates tilted sedimentary rocks.

The lavas capping Horace Mesa were erupted from four vents of the central type and from one fissure. Plate $12, A$, is a view of one of the cones. The descriptions of basaltic lava and cones on La Jara Mesa and Mesa Chivato apply to Horace Mesa, and only unusual features will be mentioned here.

Along the west side of Rinconada Canyon, about 2,000 feet south of the experiment station of the New Mexico Agricultural College, is one of the few exposures of basalt erupted from fissures in this field. Here a

${ }^{6}$ Clarke, F. W.. Analyses of rocks and minerals from the laboratory of the United States Geological Survey, 1880-1008: U. S. Geol. Survay Bull. 419, p. 123, 1910, dike is exposed reaching the erosion surface on which it was erupted. An elongate cone has been built, marked chiefly by highly scoriaceous basalt and laose cindars. Apparently only a single flow was supplied by the fissure. Three-quarters of a mile south of this locality there is another exposure of basalt, probably erur ${ }^{+}$ed along the same fissure. At this exposure there are two cones, each about 250 feet high.

Just east of the northernmost exposure of the eruptive is an outcrop of basalt interpreted as part of an early flow. The outcrop is about 200 feet wide on an eastward-trending promontory. The basalt lies upon 6 feet of light-colored tuff, which in turn overlies Cretaceous sandstone. The tuff has been baked brick red by the basalt. The flow is about 30 feet thick, is jointed in vertical columns, and locally has a highly scoriaceous upper surface. Above the flow is rhyclite tuff erupted by Mount Taylor. This overlying tuff is not baked. At other localities basalt is known to have preceded the porphyritic andesite from Mount Taylor, but this is the only known locality where basalt prece led the rhyolite.

The basalt sheets on Horace Mesa were erupted after the folding of the McCarty syncline and also after the eruptions of Mount Taylor. But along the west side of the mesa a later fault, trending nearly due north, displaces the lava about 150 feet down to the west.

\section{THE VOLCANIC NECKS}

The sheet eruptives originally covered a much greater area than at present. At several localities cited above erosion has exposed natural cross sections of the volcanoes, but locally the lava has been completely removed from around the volcanic centers leaving only the resistant core. These cores, or necks, are striking topographic features in the area, particularly in the Rio Puerco Valley northeast of Mount Taylor. The general aspect of the necks has been discussed by Dutton, ${ }^{7}$ and subsequently Johnson ${ }^{8}$ described many of the individual necks in more detail. The present study confirms the essential conclusions of the earlier investigators.

Presumably the basalt sheets that cap Mesa Chivato and Mesa Prieta were once more or less connected on surfaces that were continuous across what is now the intervening Rio Puerco Valley, and the necks are the roots of volcanoes that supplied the sheets. There are about 50 necks of various sizes and dimensions distributed through the volcanic field. Most of them are east of Mesa Chivato, but two are west of the mesa and two others south of Mount Taylor.

Some of the necks are composed mostly of basalt, others are mostly basaltic breccia, but most of them are a mixture of basalt and basaltic breccia. The brescia

\footnotetext{
7 Dutton, C. E., Mount Taylor and the Zuñi Plateau: U. S. Geol. Survey 6th Ann. Rept., pp. 166-179, 1885.

8 Johnson, D. W., Volcanic necks of the Mount Taylor region, N, Mex.: Geol. Şọc. America Bull., vol. 18, pp. 303-324, 1907.
} 
is very friable and so easily eroded that necks of breccia are less conspicuous topographically than the others. The breccia consists of inclusions of sedimentary rock and basalt in a friable glassy matrix that commonly hes a distinct flow structure. The basalt inclusions are in general highly scoriaceous and commonly have flow structure parallel to the flow of the matrix. This parallelism of flow stricture in separated basalt inclusions indicates that they were plastic or liquid masses during the formation of the breccia.

With few exceptions the country rock adjoining the intrusions was not deformed. At two localities minor tilting of adjacent beds occurred, but there was ro contact metamorphism except a very slight induration.

\section{Cabezon PEak}

Cabezon Peak (pl. 13, A) is the highest and most impressive of the necks, rising nearly 2,000 feet above the Rio Puerco, and the protruding basaltic core is about 1,500 feet in diameter. The diameter of the pipe is probably at least 2,000 feet, as indicated by poor exposures of basaltic breccia around the base of the basalt core. The country rocks intruded by the neck are Cretaceous sandstone and shale that dip gently northward, and although the contact is not exposed there is no indication of deformation by the intrusion. The exposed neck is nearly cylindrical and is about 800 feet high. It consists of dense columnar-jointed basalt below and highly scoriaceous basalt on top (pl. 13, B). The joints in the dense basalt immediately below the scoriaceous top are nearly vertical, but downward they flare slightly toward the peripheral contact. It is not certain whether this flaring is due to greater depth, as Johnson ${ }^{9}$ has suggested, or whether the base of the neck is closer than the top to the side contacts. The jointed columns range from a few feet to 8 feet in diameter. Throughout the neck the jointing is much more regular than is common in the other necks, probably because of the absence of basaltic breccia except along the contacts.

Cabezon Peak is slightly higher than the basalt sheets on Mesa Prieta, but these sheets rise gently northward and if projected would approximately coincide with the top of the peak. The thick cap of scoria on top of the peak is probably a remnant of a cone built on the surface of eruption.

The basalt at Cabezon Peak consists of about 60 percent of calcic plagioclase (labradorite?), 15 percent of olivine, 20 percent of augite, and 5 percent of magnetite. The feldspar is anhedral, with indistinct borders. The olivine is commonly in considerably resorbed or altered phenocrysts. The augite is commonly in small euhedral cyrstals, but the magnetite is disseminated in slightly larger crystals.

'Johnson, D. W., Volcanic necks of the Mount Taylor region, N. Mex.: Geol. Soc. America Bull., vol. 18, p. 322, 1907.

\section{CERRO DE LOS CJATES}

The Cerro de los Cuates, 4 miles west of Cabezon Peak, is an elongate mass of intrusive basalt now rising about 500 feet above the nearby country. The exposed main intrusive trends east of north and is e timated to be about 1,200 feet long and 500 feet wide. The adjoining rocks are Cretaceous sandstone and sandy shale. A narrow dike, about 28 inches wide, can be traced northward for about 2 miles from a point near the north base of the neck. Probably the neck is an expanded part of the dike and thus appears to have been erupted along a fissure. This association of dike and neck is closer than elsewhere in this volcanic field, for most of the necks are of the central type.

There is little basaltic breccia at the Cerro de los Cuates except along the side contacts, which are best exposed on the east side. Jointing at high angles to the side contacts is well developed in the basalt. Toward the top of the north peak, however, the joints dip into the neck, but the significance of this attitude is uncertain, because in other necks the intrusion of basalt was preceded by basaltic breccia, and so this upward flaring of the joints may reflect contact with an overlying breccia mass.

Petrographically the basalt at the Cerro de los Cuates is like that at Cabezon Peak. In the one thin section examined the following percentages of essential minerals were estimated: Labradorite, 65 percent; olivine, 15 percent; augite, 15 percent; magnetite, nearly 5 percent. The feldspar is in small euhedral laths. The magnetite is finely disseminated, though locally it is concentrated as aggregates of minute crystals.

\section{NECK IN GONZALES CANYON}

An inconspicuous intrusive mass of basaltic breccia in Gonzales Canyon, about 2 miles west of $\mathrm{C}$-sa Salazar, provides some of the most interesting expo iures in the volcanic field. (See fig. 11.) The intrusion is nearly circular and about 500 feet in diameter, and no basalt core is exposed. The exposures are about 1,500 feet below the erosion surface on which the sheet basalts were erupted. The country rock is sandstone, separated from lower sandstones by 800 feet of shale and from higher sandstones by 400 feet of sandy shale.

The basaltic breccia consists of a friable glassy matrix containing fragments of scoriaceous basalti and abundant xenoliths of sedimentary rock as much as $3 \frac{13}{2}$ feet in diameter. Most of the xenoliths are sar dstone, and several facts indicate that most of them vere derived from the sandstone adjoining the intrusion: (1) Some of the sandstone xenoliths are abundantly fossiliferous (pl. 14, B), and the fossils indicate a stratigraphic position no lower than the exposed sandstone; (2) sandstone xenoliths near the contacts of the intrusion are commonly larger, more angular, and more abundant than at the center of the intrusion, suggesting a gradual 
incorporation of the sarc'stone by the intrusive; (3) the sandstone surrounding the intrusion is highly fractured for a width of 250 feet, and breccia has been squeezed into some of the fractures.

The disturbed zone around the intrusion consists of a series of very small ringlike (concentrically arranged) faults whose traces are roughly parallel to the sides of the intrusion. The sandstone is downfaulted, and the faulted blocks are tilted toward the intrusion, producing a total subsidence of nearly 100 feet. Two narrow ring dikes of basaltic breccia were intruded along minor fractures.

The basaltic breccia at this intrusion is entirely similar to breccias at the large necks definitely related

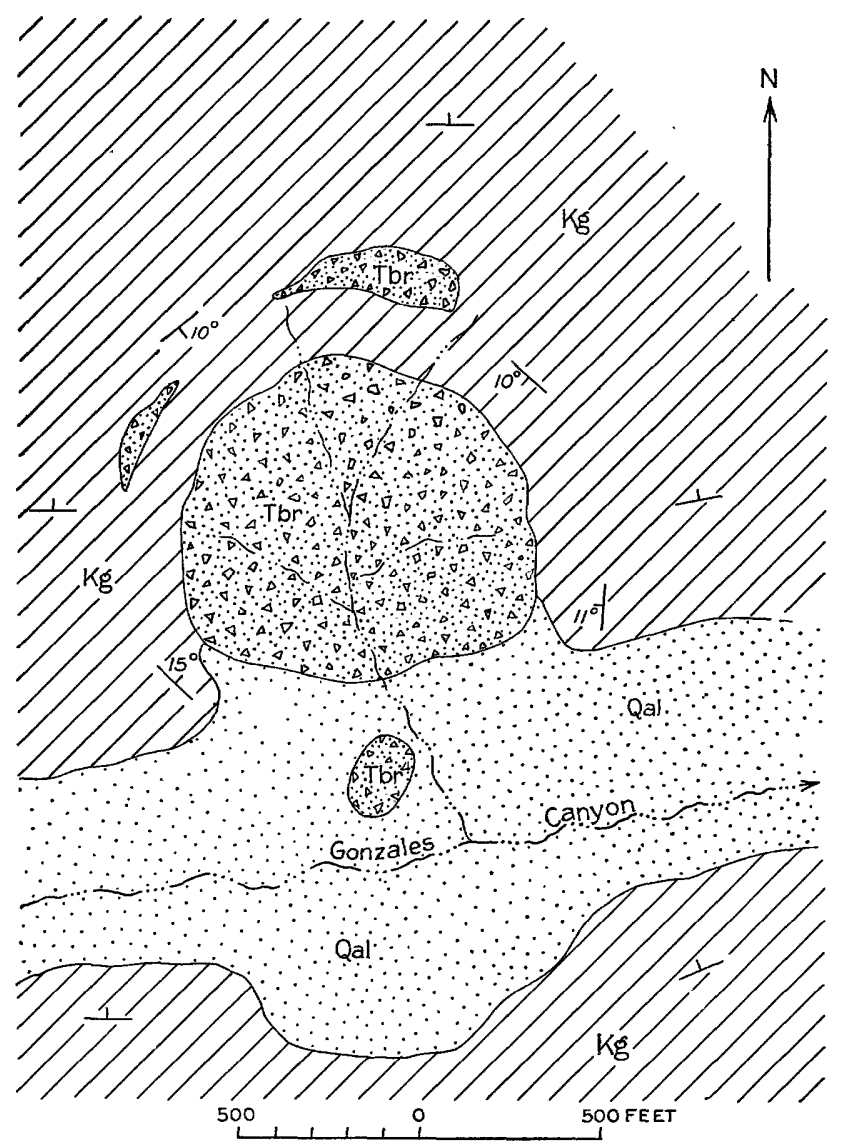

Figure 11.-Sketch map showing intrusive basaltic breccia in Gonzales Canyon. $\mathrm{Tbr}$, Basaltic breccia; $\mathrm{Kg}$. Mesaverde sandstone with strikes and dips indicated; Qal, alluvium.

to the sheet basalt series and is assumed to be a part of that series. The intrusion, however, may not have penetrated much higher than its present position. The breccia is interpreted as formed by the alteration of a roof rock foundering above a rising column of basalt (p. 72).

\section{LA SEÑORA PEAK}

The neck referred to by Dutton and Johnson as Great Neck is locally called La Señora Peak. It is an intrusive mass of basalt and basaltic breccia. It is about threequarters of a mile in diameter and may extend northward for another mile and connect with the basaltic breccia exposed there. Most of the intrusive is basaltic breccia, but toward the south there is increasingly more basalt, culminating in the peak. The basalt in the poak is jointed in columns that are vertical except near the base, where they flare toward the contacts. The top of the neck, as at Cabezon Peak, consists of scoria, which is probably a remnant of the cone or crater above the neck.

Sedimentary rocks are exposed near the south side of the intrusive and are neither baked nor tilted. However, near the north base of the peak there is in the basalt a shale xenolith thoroughly indurated by baking. Although the metamorphism consisted only of the induration and baking, this xenolith is in striking contrast to the unaltered country rock along the contacts of these intrusives. The metamorphism of the xenolith is attributed to its position above the basalt.

A puzzling exposure in the valley along the west side of La Señora Peak shows banded basaltic breccia o"verlain by scoriaceous basalt and dipping $25^{\circ}$ away from the peak. The contact between this breccia and the country rock is concealed except on the hillside above the valley, where the contact dips $20^{\circ}$ into the breccia. Apparently this mass is now completely isolated from the basalt peak. The suggestion is strong that this is a surface flow, but better exposures of rocks in similar relations elsewhere indicate that the mass is intrusive.

\section{SEBOYETA PEAK}

Seboyeta Peak (pl. 16, A), 2 miles east of the village of Seboyeta, is an elongate intrusive of andesitic breccia and andesite penetrating shale and tlinbedded limestone. It trends slightly east of $n c^{n t h}$ and is about 1,500 feet long and about 800 feet wide. A nearly vertical contact with the shale is locally exposed along the east side of the neck. Probably the intrusive continues to the north and south as narrow dikes.

The neck is composed mostly of breccia intruded by irregular narrow dikes of andesite (pl. 16, B). The breccia consists of a chaotic assemblage of boulders of sedimentary rock and scoriaceous andesite in varying proportions in a glassy matrir. Banding is crude and nearly vertical.

A series of andesite dikes ranging in width from 1 to 10 feet intrudes the breccia in the southern half of the neck. These dikes trend at an angle of $45^{\circ}$ to the long axis of the neck and are spaced fairly regularly at intervals of 50 to 100 feet. In the north half of the neck the dikes are more irregular in trend and vary considerably in thickness. There are in addition many irregular stringers of andesite in the breccia, probably for the most part offshoots from the dikes. An interesting relation was found where one of these dijkes intruding breccia is deflected around a boulder of sandstone, 
The andesite at Seboyeta Peak consists roughly of 45 percent of calcic andesine, 10 percent of augite, 15 percent of olivine, and 5 percent of magnetite in an indeterminate groundmass that probably is mostly feldspar.

\section{BASALTIC ROCKS BY NEW MEXICO STATE HGHWAY 6}

Where New Mexico State Highway 6 crosses the Rio Puerco there is exposed a conical mass of basaltic breccia and basalt south of the highway and a flow of basalt just north of the highway. The contacts of the conical mass are concealed by alluvium. At the edge of the alluvium interbedded basalt and banded basaltic breccia dip $45^{\circ}-70^{\circ}$ into the cone. The top of the cone is red, highly scoriaceous basalt. Whether this cone is truly a lava and cinder cone partly concealed by alluvium or merely a neck left protrudirg by erosion of the surrounding country cannot be fully determined. The basaltic flow with no other known nearby source suggests that the conical mass is a lava and cinder cone. However, masses similar to this cone and known to be necks are exposed in other parts of the Mount Taylor field.

The basaltic flow north of the highway overlies part of the Santa $\mathrm{Fe}$ formation and is overlain by higher beds of that formation (pl. 19, B). At the larsest exposure adjacent to the highway the lava is tilted above $8^{\circ} \mathrm{S}$., and a small fault displaces the north edge of the exposure. Other exposures to the northeast show that the dip of the lava changes to east in conformity with the change in dip of the Santa Fe beds. The flow is much lower than the sheet basalts nearer Mount Taylor, but this may be due partly to downfaulting (p. 77). The flow is probably either contemporaneous with or younger than the sheet basalts around Mount Taylor.

\section{SIERRA ALESNA}

The Sierra Alesna lies northwest of Mount Taylor, about 10 miles north of San Mateo. The neck intrudes sandstone and shale and rises 1,200 feet above the surrounding area. The country rock is well exposed on the north side, about 600 feet below the top of the neck, and though within 175 feet of the neck is neither tilted nor baked. The intrusive mass is nearly circular and therefore of the central type, but several outliers of andesite south of the neck are undoubtedly connected with it by a dike trending slightly east of north.

The neck is composed entirely of dense andesite jointed in nearly vertical columns. Near the base the joints dip about $70^{\circ}$ toward the contact, but they curve upward and at the top dip about $80^{\circ}$. These joints produce the structural control that has given the neck its awl shape, from which the Spanish name for the peak was taken. Around the base of the neck the joints are a little over 1 foot in diameter. They are four- to six-sided, though most have only four sides.
The andesite consists of about 40 percent of oligoclase, 10 percent of hypersthene, 35 percent of augite, 5 percent of olivine, and 10 percent of magnetite.

OTHER VOLANIC NECKS

The other necks are also composed of exrly basaltic breccia and later basalt intruded into Upper Cretaceous sandstone and shale. A few of the necks are elongate and may have been erupted from fissures, but most of them are cylindrical (pls. $12, B ; 15, A$ ). There is a very slight upward drag of strata in contect with the neck east of La Abra de los Cerros. At the small andesite intrusions 4 miles east-northeast of La Señora shale in contact with the andesite is indurated for about 1 inch from the contact, but at 8 inches from the contact no alteration is discernible. Elsewhere the intrusions neither tilted nor altered the adjoining country rock. A contributing reason for the general absence of metamorphism, however, is probably the common occurrence of breccia between the basalt and the country rock.

The basaltic breccia consists of xenoliths, some of them many feet in diameter, of sedimentary rocks and basalt. Most of the basalt inclusions are highly scoriaceous, but some are dense. The fragments of sedimentary rock are generally well rounded and enclosed by a zone of alteration. The matrix of the breccia is friable glass, commonly with distinct flow structure. Much of the breccia shows banding, which is at least partly due to varying proportions of sedirnentary and basalt inclusions. The bands are commonly tilted but. not folded. Isolated inclusions of basalt as a rule show a flow structure mutually parallel and parallel to the banding. At Santa Rosa Peak, as at La Sañora Peak (p. 69), the banded breccia dips at fairly steep angles away from the neck. More commonly, however, the breccia along a contact dips toward the neck, generally between $10^{\circ}$ and $40^{\circ}$ (pls. $14, A ; 17, B$ ). Breccia is generally present along the contacts, but irregular masses of breccia also occur throughout some of the necks.

Many of the necks have cores of basalt, and this basalt was intruded after the breccia was formed. Some of these cores contain little or no breccia, as at Evans Peak (pl. 15, $A, B$ ); others contain abundant breccia-for example, the neck west of La Abra de los Cerros and Cerro Chato. Still other necks contain intermediate proportions of breccia and basalt. Wherever breccia is scarce the basalt is jointed in fairly regular columns, and near the contacts the columns are parallel to platy joints that are developed along the contact. At these localities, therefore, cocling of the basalt progressed downward from the crater rather than inward from the contacts. Where breccia is associated with the basalt there is generall $r$ a zone of platy-jointed basalt next to the breccia, and the columns show a strong tendency to curve toward the plates. 

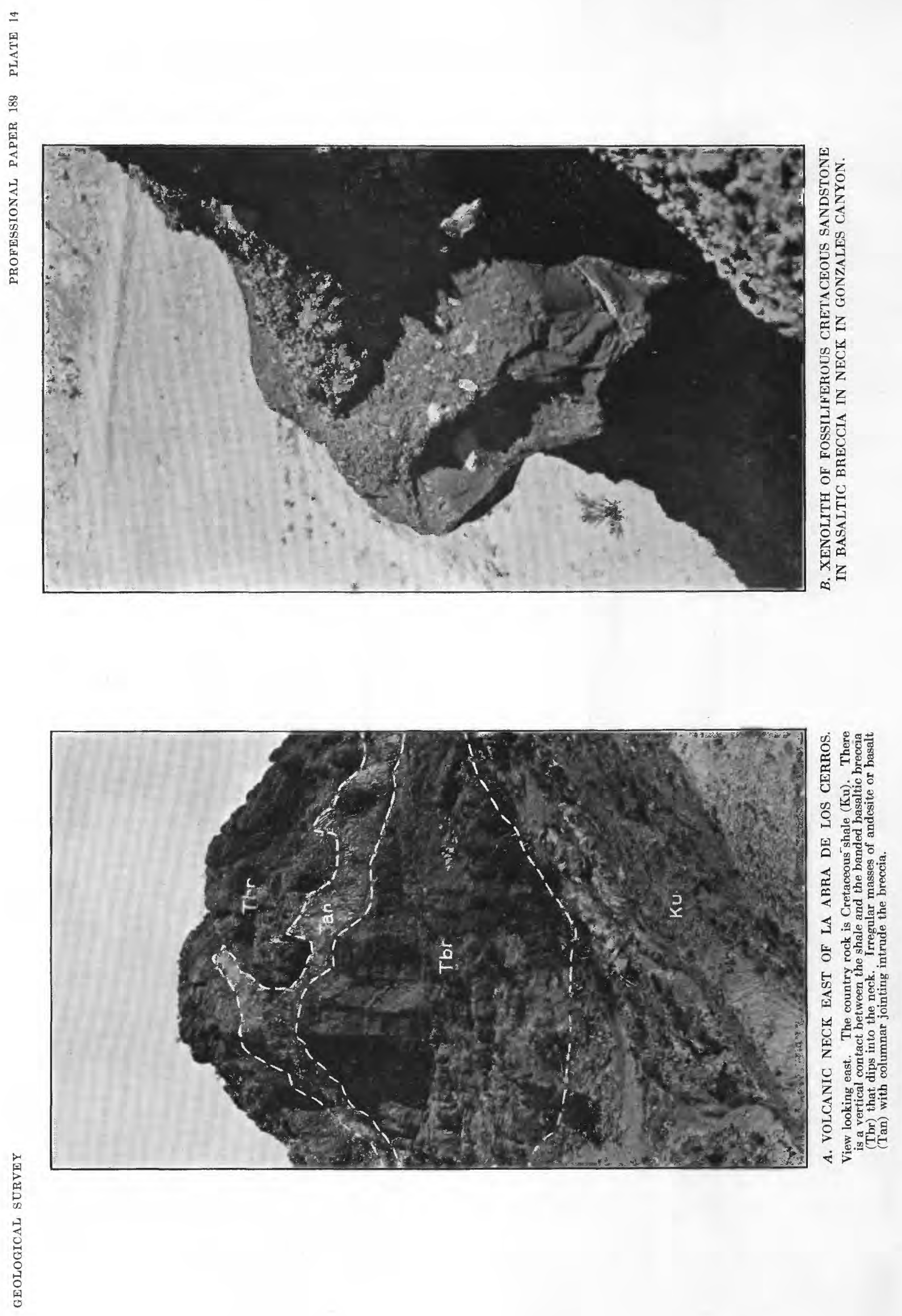


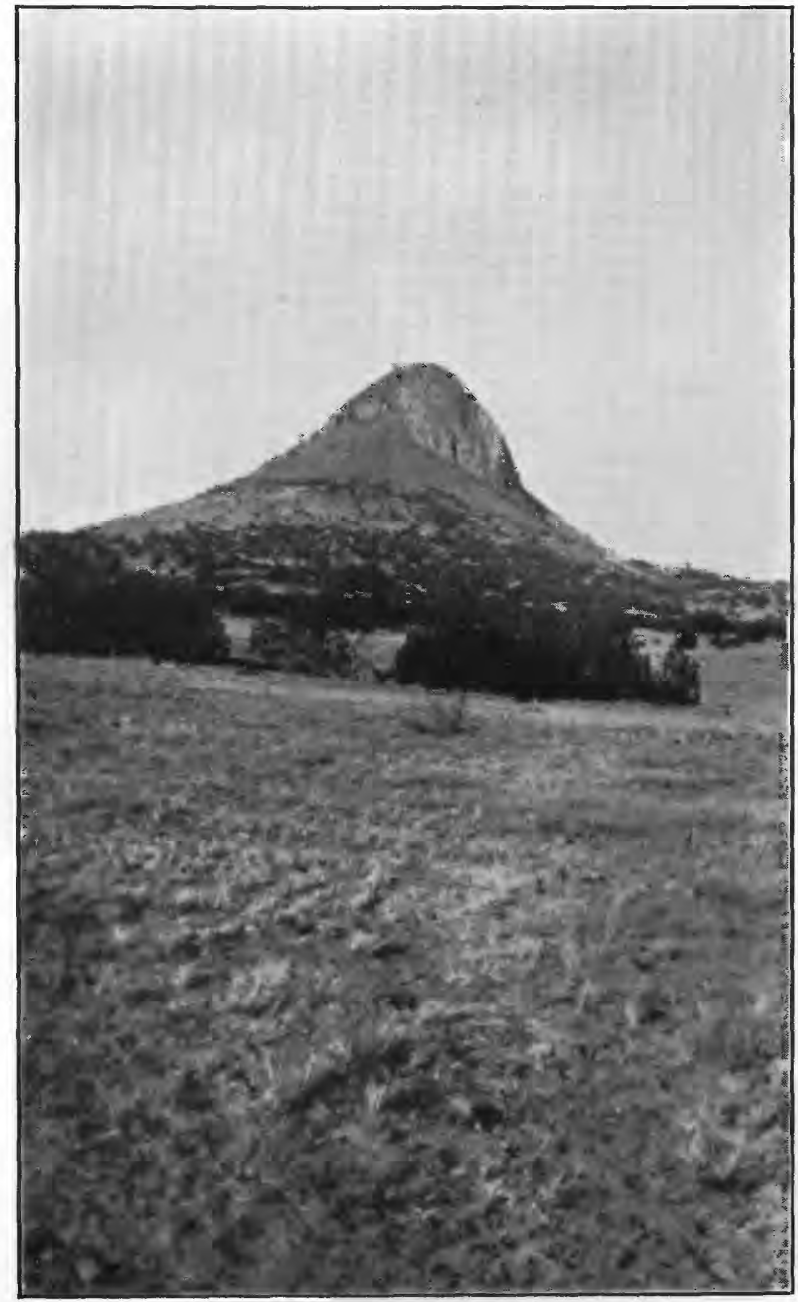

A. VIEW FROM THE EAST.

The neck is composed of andesite (possibly basalt) and protrudes about 1,100 feet above the level of the foreground. Photograph by D. A. Andrews.

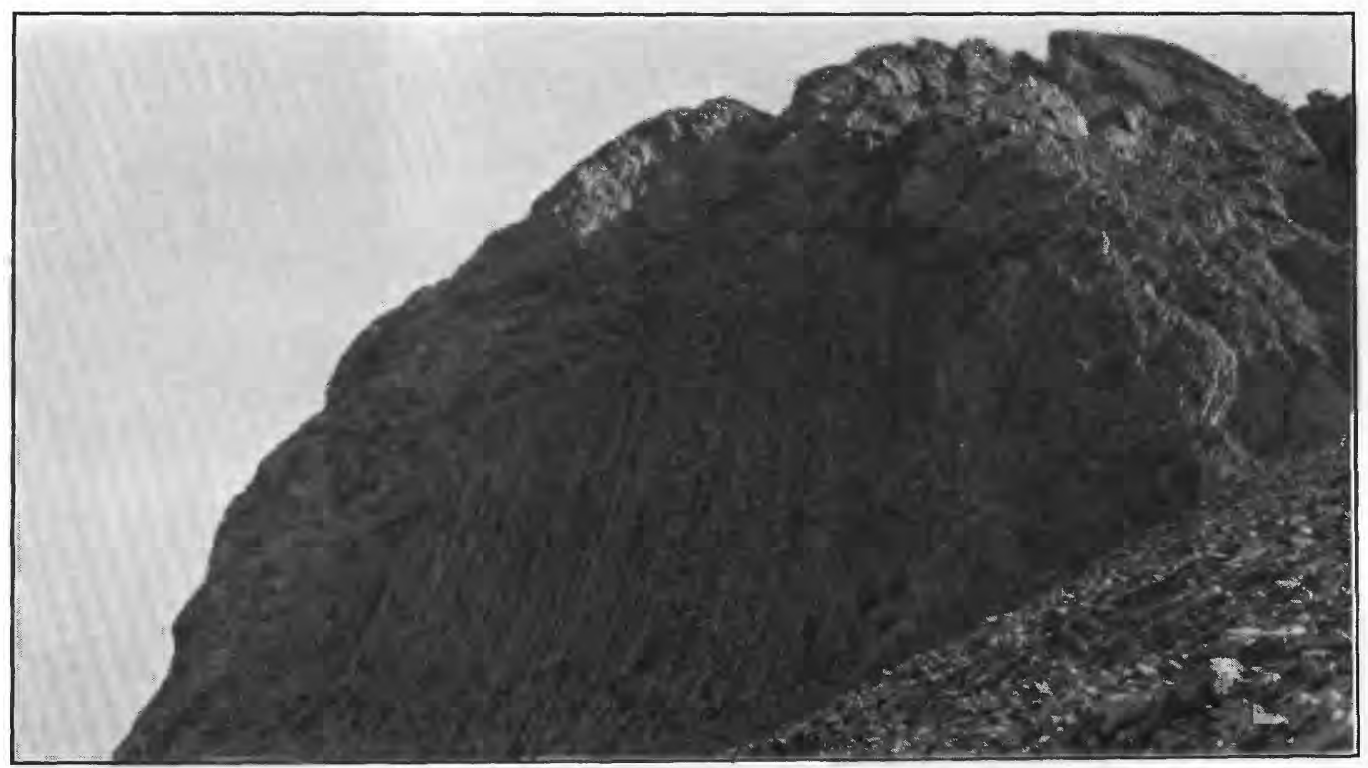

$B$ DETAIL OF COLUMNAR JOINTING AND OUTER SHELL OF IRREGULAR PLATY JOINTING. Photograph by R. C. Becker.

VIEWS OF EVANS PEAK. 


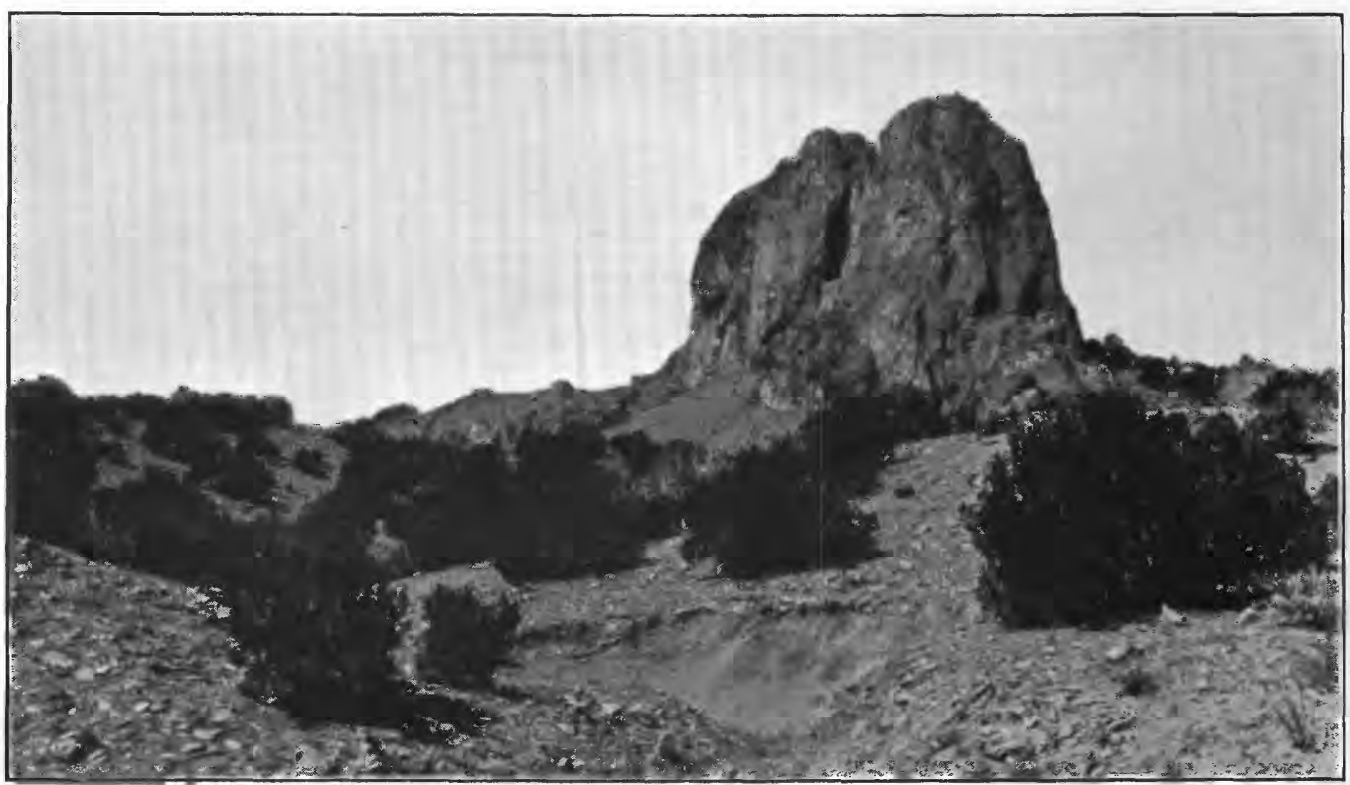

A. VIEW LOOKING SOUTHWEST TOWARD SEBOYETA PEAK.

The peak is composed mostly of andesitic breccia intruded by andesite dikes, some of which can be seen at the left protruding above the lower part of the neck.

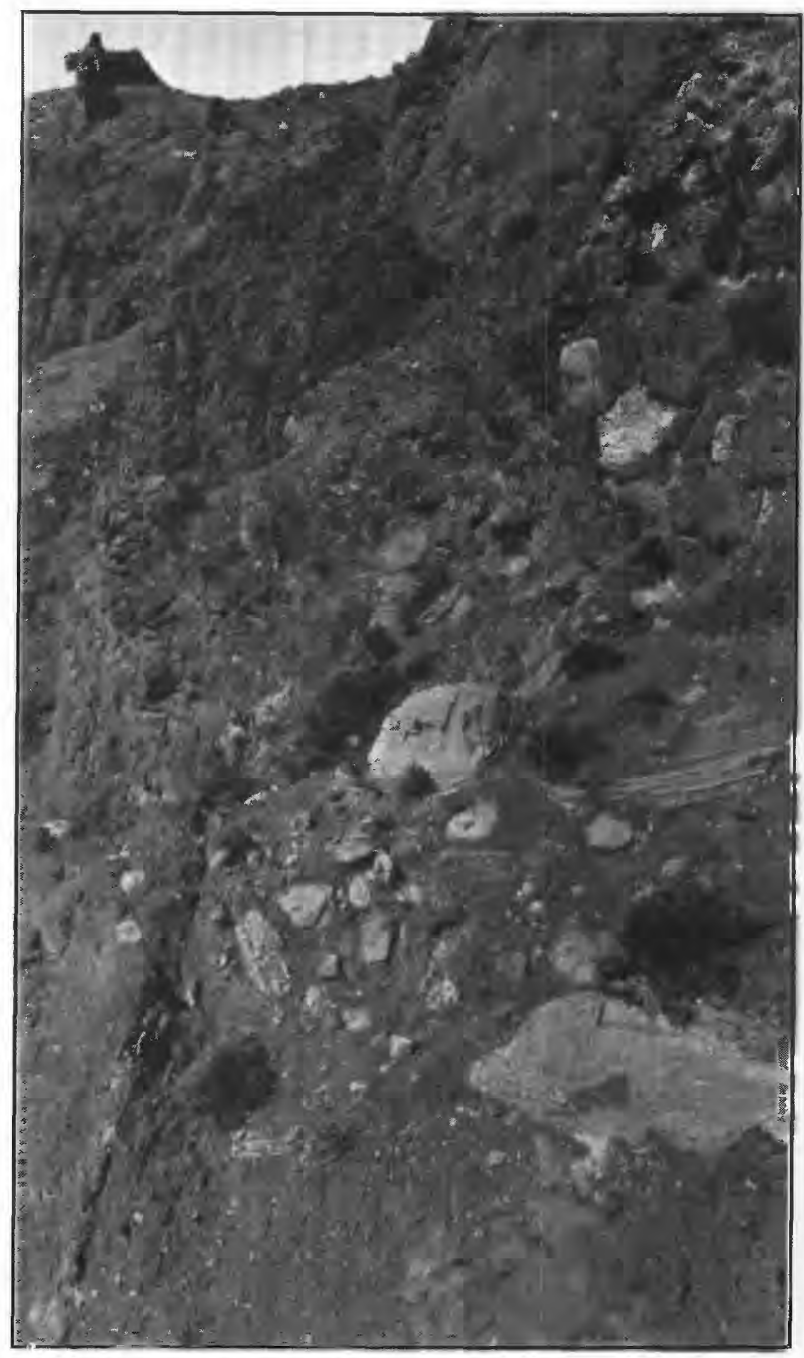

B. XENOLITHS OF SEDIMENTARY ROCK IN BRECCIA ALONG EAST SIDE OF SEBOYETA PEAK. Andesite dikes, protruding as dark masses, can be seen at the upper left. 

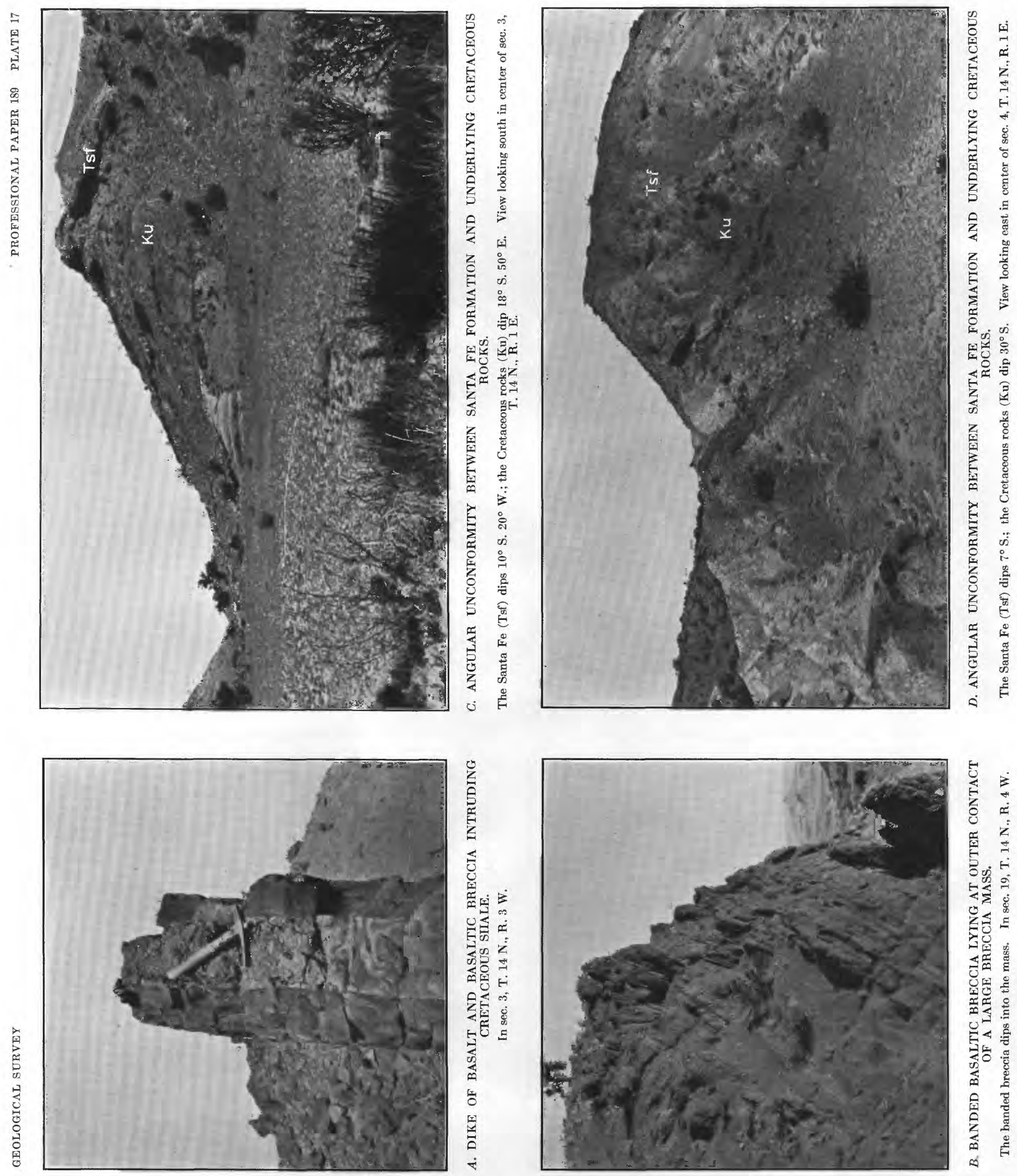
These relations occur around xenolithic masses of breccia as well as against the breccia along the contacts (fig. 12).

Even in the very small intrusive 4 miles east-northeast of La Señora Peak there is evidence of considerable loss of heat upward. The rock is andesite jointed

N.

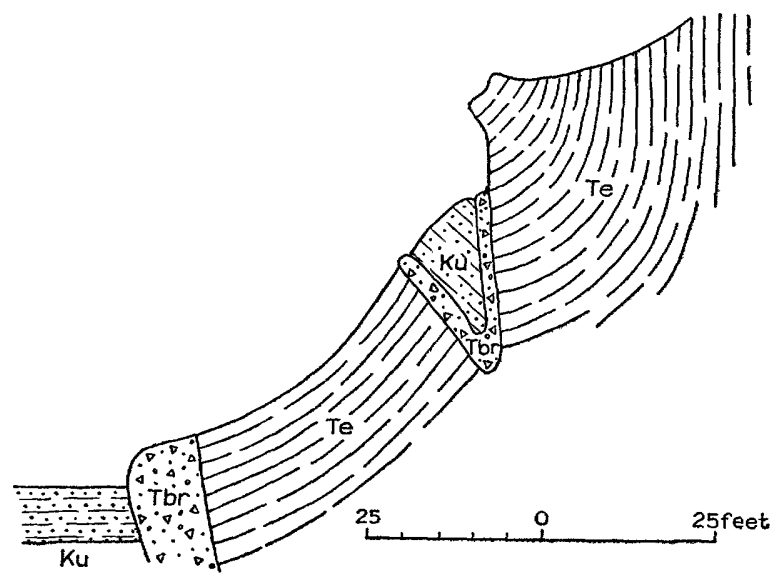

Figure 12.-Diagrammatic section through north side of Juan Tafoya Peak. Ku, Cretaceous shale and sandstone; Tbr, basaltic breccia; Te, basalt. The trend of columnar joints in the basalt is indicated by the broken lines.

in columns that in plan radiate from the center of the mass (fig. 13). In cross section, however, the columns are horizontal against the outer contact with Cretaceous shale, but inward the columns curve upward and at the center are nearly vertical. At Picacho Peak, southeast of Mount Taylor, the joint relations provide a notable exception to these general descriptions. The intrusive mass is elongate and consists wholly of dense andesite jointed in columns that are horizontal and normal to the side contacts.

The basalt in most of the necks contains 60 to 70 percent of sodic labradorite or calcic andesine, 15 to 25 percent of augite, 5 to 15 percent of olivine, and magnetite. The olivine occurs commonly in large phenocrysts: one that was collected is nearly 1 inch long. Where basalt solidified against breccia considerable glass developed, but where basalt solidified against basalt there is little glass.

\section{BASAIT DIKES}

Numerous basalt dikes, probably related to the basaltic sheet eruptions, are exposed in the Mount Taylor volcanic field. All trend morth, conforming to the regional strike of the faults, but only one (p. 72) is known to have been intruded along a fault surface. The dikes are most abundant east of Mount Taylor and Mesa Chivato, but a few are locally exposed south of the mountain. The dikes are thin, most of them about 2 feet thick, but some attain a maximum of about 30 feet.

On the north line of sec. 2, T. 14 N., R. 4 W., about 3 miles west of Casa Salazar, a nearly vertical dike trends slightly east of north. The dike intrudes shale and can be traced almost continuously for several hundred feet. It is nowhere more than 2 feet in tl ickness and generally about 18 inches. Locally the dike is composed wholly of basalt horizontally jointed in small columns normal to the side contacts. Elsewhere basaltic breccia is associated with the basalt, occurring along one side of the dike or more commonly in the middle. Plate 17, $A$, shows an outcrop where basaltic breccia separates two basalt portions of the dike, a relation that persists for a considerable distance along the outcrop. This outcrop is particularly interesting in connection with the necks, because the breccia, like that in the necks, contains small xenoliths of sedimentary rocks and highly scoriaceous basalt in $\varepsilon$, friable glass matrix. On each side of the breccia there is basalt 6 to 8 inches wide jointed in horizontal columns. The basalt in contact with the shale is dense and nonscoriaceous, but there are vesicles along its contact with breccia, strongly suggesting that the brescia allowed release of pressure existing in the fluid basalt. This exposure is about 1,500 feet below the erosion surface on which the sheet basalts were eruptec'. The lithology of this dike suggests that it is related to the sheet basalts and to the necks, but it may hare been intruded during the later period of minor faulting that occurred in this part of the volcanic field wh on the drainage system was between 100 and 900 feet above its present position (p. 75). The basalt in this dike consists chiefly of calcic andesine with some augite and traces of magnetite in a glassy groundmass.

A basalt dike trending east of north crops out at intervals near or along a fault about 3 miles westnorthwest of Casa Salazar. If the dike is continuous, as seems likely, its thickness ranges from about 18 inches to 6 feet. It is composed mostly of basalt crudely jointed in horizontal columns. At one locality a dikelike offshoot extends a few hundred feet to the west. Where it joins the main dike there

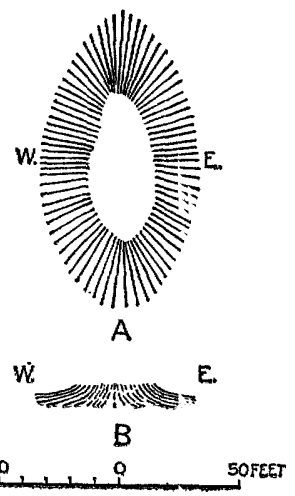

Frgure 13.-Diagram of columnar jointing in intrusions 4 miles east-northeast of La Señora Peak. A, Plan of radial jointing; $B$, Eastwest cross sectio? showing center of intrusion. joints curving urward near is considerable breccia, and the associated basalt is very irregularly jointed.

At Paguate Indian pueblo a dike crops out that can be traced southward for about 2 miles and northward for about 1 mile. The dike ranges from 2 to 12 feet in width and intrudes thick sandstones and interl ndded shale. It is mostly breccia, consisting almost wholly of friable glass containing small fragments of sedimentary and igneous rock, with locally a ver: thin border zone of basalt. The dike is more easily eroded than the enclosing sandstones and forms a depression where it cuts them. It is about as susceptible to ero- 
sion as the soft shale, and where shale is the country rock exposures of the dike are few except in arroyos. No evidence of alteration of the country rock was observed anywhere along the dike.

Only one dike is known in the severely faulted portion of the area. The outcrop, a mile southeast of the Ojo Escondido fault, $4 \frac{1}{2}$ miles east of Suwanee, was found by G. F. Taylor. The dike trends about N. $25^{\circ}-30^{\circ} \mathrm{E}$. and dips $65^{\circ} \mathrm{NW}$. The trend closely parallels that of the many nearby faults, but no displacement was found along the dike. The rock is finely crystalline andesite composed mostly of calcic andesine, considerable augite, a little magnetite, and traces of olivine.

Another dike crops out about 1 mile northeast of MeCarty, south of Mount Taylor, and there are several others near Chico Arroyo, north of Mesa Chivato. Most of these dikes parallel the trend of nearby faults, but, so far as known, none of them follow fault surfaces.

At the mouth of Rinconada Canyon, south of Mount Taylor, H. R. Joesting and R. C. Becker found Cretaceous sandstone and shale displaced 150 feet by a fault along which a basaltic dike was intruded. The dike is 30 feet wide and closely follows changes in trend of the fault. Toward the south end of the exposure the dike widens considerably, and higher volcanic rocks funnel out over tuffs, about 70 feet thick, that probably belong to the rhyolite tuff series erupted by Mount Taylor. The higher volcanic rocks may be a remnant of an elongate cone built by a fissure eruption. Both the fault and the dike die out beneath the cone and do not extend farther south. This is the only known locality in the Mount Taylor volcanic field where a dike follows a fault fissure. The occurrence is also unusual for this field in that the basalt is relatively very coarsely crystalline and could be described as dolerite. It is composed of sodic labradorite, augite, and minor quantities of olivine and magnetite.

\section{ORIGIN OF THE BRECCIA}

It seems probable that the breccia is a nonextruded byproduct of the intrusive process. My reasoning is not that certain facts indicate an intrusive process but that those facts are difficult to explain by a theory of pyroclastic origin. The evidence may be summarized as follows:

1. Under a theory of pyroclastic origin each breccia mass must represent several falls of fragmental material. But the material now preserved could not have fallen back into the vents after each explosion, for the bands are a conformable series. Each breccia mass must have fallen back as a large unit block (pl. 17, B), a landslip from the cone. But none of the preserved cones are composed of such material.

2. If the tremendous quantity of breccia now preserved in the necks represents pyroclastic material that fell back into the vents some pryoclastic material should be preserved with the lavas. There is practically none. Thin beds of light-colored tuff locally interbedded with the basalt sheets bear no re emblance to the basaltic breccia. Locally where there are natural cross sections of the volcanoes, as in Marquez Canyon, large masses of breccia are preserved along tl 9 walls of the pipe, but little or no breccia occurs with the overlying flows. Some basaltic flow breccia expored in the Grant Ridges (pl. 11, A) differs from the breccia in the necks by the comparative absence of a cementing glass matrix and very low proportion of sedimer tary rock fragments. It consists almost wholly of boulders of frothy basalt.

3. As the breccia is lighter than the basalt the breccia masses, if pyroclastic, must have fallen into open conduits. But some of the conduits are very narrow fissures many hundreds of feet deep in poorly consolidated shale (p. $71 ;$ pl. $17, A$ ). It is unlikely that they could remain open to collect debris from the surface.

4. At the breccia neck in Gonzales Canyon most of the fragments are sandstone, in part fossiliferous and surely derived from the adjacent sandstone formation (p. 78). These inclusions are practically at their original location. Furthermore, they grade from largo angular blocks near the side contacts to fine particles in the interior of the intrusion.

These relations are more consistent with an assumption that the breccia is of nonextrusive origin. But the rising columns of basalt did not fold or fault the adjacent country rock and produced practically no drag along the side contacts, so the breccia is attributed to progressive alteration and incorporation of roof rock by the rising intrusions. Each of the strata is visualized as being progressively more altered and deformed as the intrusions rose, and at any given time there was complete gradation from undisturbed roof rock through breccia to relatively unadulterated basalt.

Whatever hypothesis is proposed must confine the disturbing effects of the intrusions to a pipslike zone through the roof rock, and the subsequent intrusion must occupy all of that pipe, because the sedimentary rocks beside the intrusions are not disturbed. Probably the pipe of the deformed strata was a long slender cone, and in each stratum the first ef ect of the intrision was at a point-the apex of the cone. As intrusion contirued the cone of disturbance was extonded upward, and in each of the strata the disturbed area was extended laterally.

Probably the first effect was a baking and induration. This would culminate in abundant jointing and, in water-bearing sandstone, further fracturing by steam explosions. A push upward or a downward settling at this stage would develop minor faults across and ring faults around the fractured zone, contributing to further break-up of the roof. The upper part of the lara column, probably more frothy and richer in volatile constituents than the main column, could be intruded alon $\%$ the frac- 
ture planes, and the addition of this material would convert the breccia to a plastic mass. Considerable churning of the plastic breccia would comminute the fragments of sedimentary rock and intimately mix the fine particles with the enclosing medium. Irregular stringers of basalt intruded at this stage would be churned in with the breccia and form isolated and relatively pure masses of basalt in the breccia. Rise of the basalt column through this mass would squeeze the breccia against the side contacts and there develop the banding and flow lines.

This hypothesis does not satisfactorily explain why the banding and flow lines of the breccia masses so commonly dip into the intrusions. But to assume that the masses were rotated to this attitude by rise of the adjacent basalt column is as reasonable as to assume that they descended from the surface into open conduits, as required by the theory of pyroclastic origin.

Basalt in the breccia is commonly highly scoriaceous, and this is the chief basis for the pyroclastic hypothesis. However, the superior jointing of basalt in contact with breccia indicates that the breccia was more potent in promoting consolidation than the sandstone or shale of the country rock. Furthermore, basalt in contact with breccia commonly developed vesicles, but basalt of the same intrusion in contact with sedimentary rocks is dense. Apparently, therefore, the breccia allowed relief of pressures and release of any gases that may have been contained in adjacent basalt, and this facilitated consolidation with development of vesicles.

\section{SUMMARY OF BASALT ERUPTIONS}

Sheets of basalt were erupted from a large number of vents distributed around Mount Taylor. One local basalt eruption preceded the rhyolitic tuff, and a few basalt flows preceded the later flows of the porphyritic andesite series, but the greatest volume of basalt was erupted shortly after the Mount Taylor volcano had become quiescent. Most of the flows spread out in sheets on erosion surfaces developed around the Mount Taylor cone and locally overlapped the sides of the cone. The sheets are preserved today capping high mesas that extend as foothills away from the Mount Taylor cone. Most of the sheets were supplied by eruptions of the central type, though a few fissure eruptions are known. Apparently the basalt made its way through the upper part of the crust by some process other than forcible injection, because even where the country rock is soft shale the eruptions caused no deformation.

\section{RECENT FLOWS}

Very recent flows of basalt are found in the valley bottom of the Rio San Jose along the south border of the volcanic field. These flows were given only casual attention, because none were supplied by vents within the field. Some of the vents are along the east side of the Zuñi Mountains, others are north of the villlage of Bluewater, and others are near Laguna Pueblo. The flows have exceedingly fresh surfaces, which, combined with their position in the valley bottom, make them appear as if they had been flowing only yesterday. These flows are more ferromagnesian than most of the sheet eruptives of the Mount Taylor volcanic field. They consist of labradorite with a high percentage of olivine, slightly less augite, and some magnetite.

\section{STRUCTURAL GEOLOGY}

\section{GENERAL STRUCTURAL RELATIONS OF THE VOLCANIC FIELD}

Most of the Mount Taylor volcanic field is in the Colorado Plateaus province, but the field extenc's eastward into the Basin and Range province. (See fig. 3.)

The Colorado Plateaus are represented in northwestern New Mexico by the San Juan Basin, a broad structural depression. In the interior of the basin the beds are nearly flat, but on all sides they rise gently to the bordering mountain uplifts. The north flank of the basin, in southwestern Colorado, is a steep monoclinal flexure produced by the uplift of the San Juan Mountains. A monocline forming the west flank of the basin is produced by the Defiance uplift and by a laccolithic injection at Carrizo Mountain. The east flank of the basin is in part a steep-monocline along the Nacimiento Mountains, a range of the southern Rocky Mountains, at the northeast corner of the Mount Taylor volcanic field. From the base of the monocline westward the beds dip gently toward the interior of the basin. The Nacimiento Mountains consist of a central core of basement rocks uplifted in an asymmetric anticline, with local reverse faulting along the steep west flank. On the south side alone the basin is not bordered by a monoclinal fold. A gentle northward dip prevails there, produced by the upli!t of the Zuñi Mountains and Mesa Lucero. The Zuñi, Lucero, and Nacimiento uplifts may have been more or less contemporary in the interval between early Eocene and late Miocene time. ${ }^{10}$

The south flank of the San Juan Basin, on which Mount Taylor is located, departs considerably from a simple basinward dip. West of the Zuñi Mountains is the Gallup-Zuñi Basin, a northward-plunging asymmetric syncline. Immediately east of the Zuñi Mountains is the northward-plunging McCarty syncline, a broad, shallow, symmetrical fold. The McCarty syncline extends northward into the south flank of the San Juan Basin and plunges steeply under the Mount Taylor volcano. The area shown on plate 7 therefore includes the northern extension of the McCarty s.rncline and parts of the north flanks of the uplifts on each side of the syncline.

The central and western parts of the Mount Taylor volcanic field, limited eastward by the Alamosa fault, San Ignacio monocline, and Reservoir fault, are in the

${ }^{10}$ Hunt, C. B., Tertiary structural history of part of northwestern New Mexico [abstract]: Washington Acad. Sci. Jour., vol. 24, pp. 188-189, 1934. 
San Juan Basin and constitute the portion of the volcanic field in the Colorado Plateaus.

The southwest quarter of New Mexico is in the Basin and Range province. It is an area of abundant faulting and more or less folding. In the southern part of the State, west of the Rio Grande Valley, there are overthrusts combined with folds and intersecting sets of normal faults. Along the valley, however, there are only braad northward-trending folds broken by normal strike faults that produce horsts and grabens. The folded and faulted belt of the Rio Grande Valley extends northward across the eastern part of the Mount Taylor volcanic field to the south tip of the Nacimiento Mountains.

In the Mount Taylor volcanic field, east of the Alamosa fault, San Ignacio monocline, and Reservoir fault, the block-faulted Cretaceous strata are exposed, but farther east they are concealed by the fluviatile Santa Fe formation. This part of the volcanic field is the east edge of a graben that extends 25 miles eastward past Albuquerque to Sandia Mountain. The Santa Fe formation, deposited in the topographic depression that resulted from the graben faulting, thickens rapidly eastward. The part of the Mount Taylor volcanic field lying in the graben constitutes the Basin and Range portion of the field.

The structural deformation of the Mount Taylor volcanic field began probably in late Miocene time and continued through the Pliocene (p. 56, fig. 8). In the Colorado Plateau portion of the field the movements began with the uplift of the Zuñi Mountains and Mesa Lucero, which produced the regional northward dip and the folding of the McCarty syncline. The date of the folding and faulting northwest of the syncline and the gentle warping just east of it is uncertain, but they were probably contemporaneous with these early movements. This deformation preceded the eruptions of Mount Taylor. Minor faulting east of the McCarty syncline and minor folding and faulting within the syncline occurred much later, after the eruption of the post-Mount Taylor sheets of basalt. In the Basin and Range portion of the field deformation was nearly completed before eruption of the sheet basalts and deposition of the Santa Fe formation, but some movements continued until after the eruptions, while the Santa Fe was being deposited.

\section{COLORADO PLATEAU PORTION OF THE FIELD} MCCARTY SYNCLINE

The largest fold in the Mount Taylor volcanic field is the McCarty syncline, the axis of which trends about N. $20^{\circ} \mathrm{E}$. across the central part of the field. (See pl. 7 and fig. 3.) South of this field the syncline is shallow and symmetrical, with flanks rising gently to the bordering uplifts, the structural relief for 10 miles on each side of the axis being only about 600 feet. At the south border of the Mount Taylor field there is an abrupt northward plunge. Under Mount Taylor the structural relief for 10 miles on each side of the axis is at least 1,500 feet. North of Mount Taylor the northward plunge of the syncline is considerably less than the regional dip, and near the north border of the volcanic field the syncline dies out into the regional dip. Near Mount Taylor the syncline is strongly asymmetric, the west flank being a steeply dipping monocline. This monocline extends from the south side of T. 12 N., R. 9 W., to the north side of T. 14 N., R. $8 \mathrm{~W}$. Many dip faults, mostly small, fracture the northern part of the monocline. Two miles west of San Mateo there is a strike fault with a downthrow of about 700 feet to the east, which apparently takes up most of the monoclinal displacement and dies out under La Jara Mesa. South of this mesa a second monocline produces about 1,600 feet of structural relief in about 1 mile. This monocline (fig. 5) is probably faulted, but the outcrops are so few that detailed recorstruction of it was not attempted.

Apparently the east flank of the McCarty syncline in the Mount Taylor field is fairly regular, and it dips westward at about 200 feet to the mile.

The sheets of basalt that followed the eruptions of Mount Taylor lie on erosion surfaces cut across the edges of strata dipping into the deepest part of the McCarty syncline. On La Jara Mesa the erosion surface and overlying eruptives truncate the rnonocline at the south side of the mesa (fig. 5) and the strike fault at the north side. Erosion surfaces and overlying sheet basalts truncate the northward-plunging syncline aloing the south side of San Fidel Mesa. Similar truncation of the east flank of the syncline is seen in the canyons that have been eroded into the east side of Mesa Chivato.

\section{MINOR FOLDS WTTHUN MCCARTY GYNCLINE}

There are several minor folds south of Mount Taylor in the McCarty syncline. At the head of Rinconada Canyon, in the eastern part of T. 11 N., R. ₹.W., is a dome covering about $1 \frac{1}{2}$ square miles and having a structural relief of about 1,000 feet (pl. 7).

The attitude of the Mesaverde beds at the head of the north fork of Lobo Canyon, in the southern part of T. 12 N., R. 8 W., indicates another closed fold. Because of the uncertain position of the expored rocks in the Mesaverde formation, this fold was not contoured. Probably, however, the structural relief of this fold is not as great as that of the fold at the head of Finconada Canyon.

The location of these two folds at the heads of the two largest canyons draining the southwest side of Mount Taylor is puzzling. No direct evidence was found indicating that the two folds are later than the eruptives capping the canyon rims. Although the outcrops of the flows nearly parallel the strike of flanks 
of the folds, these outcrops are so far from the area of steepest dips that no disturbance of the eruptives was noted. It would seem reasonable to interpret these domes as later than the lavas, including the sheet basalts, and also to regard the canyons as having been eroded because of the disruption of the resistant lava cap. But the basalts overlying the dome in Canyon Seco, near the south line of T. 11 N., R. 7 W., are not folded and thereby discount that interpretation.

A remarkable feature of the dome in the southeastern part of T. 11 N., R. $8 \mathrm{~W}$., is the abrupt flexure of the west flank. There is no intermediate dip between the flat beds to the west and the nearly vertical beds of the west flank. This abrupt change in dip and the fact that these domes produce considerable structural relief within very small areas suggest forces of igneous injection, but no evidence was found of alteration or baking of beds on the crests of the domes.

Folded sedimentary rocks belonging to the Mesaverde formation are exposed in the bottom of the Mount Taylor amphitheater near the east side. The easternmost beds of this exposure dip $20^{\circ} \mathrm{E}$. They are overlain by not less than 400 feet of rhyolitic tuff. The tuff also dips to the east, but the dip ranges from $10^{\circ}$ to $20^{\circ}$ and may be depositional rather than structural. The source of the tuff was the crater of the Mount Taylor volcano, not more than 2 miles to the west, and the tuff may have accumulated on dip slopes. No exposures of tuff were found associated with the steeper northward-dipping beds of the northernmost part of this Mesaverde exposure (p. 58).

That some of the faulting within the McCarty syncline was later than the formation of the high erosion surfaces and of the sheet basalt is indicated by the relations along the southwest side of Horace Mesa, where a fault trending slightly west of north drops the erosion surface and overlying basalt 150 feet on the west.

FOLDS NORTHWEST OF MCCARTY SYNCLINE

Northwest of the McCarty syncline the prevailing northward dip is interrupted by several folds. In the Mount Taylor volcanic field the folds are large and prominent structural features, as shown by the structure contours on plate 7. Westward, however, folding progressively diminishes, and near the west border of the adjoining area, mapped by Sears, ${ }^{11}$ only broad and very gentle undulations interrupt the regional dip. There is a similar diminution of intensity of folding to the northwest. ${ }^{12}$ The folds in the western part of the Mount Taylor volcanic field therefore represent a maximum of the deformation and are not representative of the south flank of the San Juan Basin.

The two sets of faults that are present in the Mount Taylor volcanic field northwest of the McCarty syncline

It Sears, J. D., The coal field from Gallup eastward toward Mount Taylor, N. Mex.: U. S. Geol. Survey Bull. 860-A, pl. 1, 1934 .

12 Hunt, C. B., and Dane, C. H., Preliminary map showing geologic structure of the southern part of the San Juan Basin, N. Mex., U. S. Geol. Survey, 1933. are found over much of the south flank of the basin. The faults are crowded in the areas of steepest folding. To the west and northwest, concomitant with the diminishing intensity of folding, the faults not only become progressively fewer but produce less displacement.

The close relationship between degree of folding and degree of faulting strongly suggests an intimate genetic relationship between the two types of deformation. It seems likely that they were contemporaneous, but it is impossible to date the movement closely. The youngest beds involved are of lower Pierre age. Probably, however, the movements were much later than early Pierre time and were related to the folding of the McCarty syncline, the most southeasterly and largest of the folds, regarded as later than early Eocene and earlier than late Miocene (p. 57, fig. 8).

\section{GENTLE WARPING EAST OF MCCARTY SYNCLINE}

East of the McCarty syncline the Cretaceous rocks are very gently folded. These rocks rise toward the east and southeast, where the undulations are terminated abruptly by faults and a steep eastward-dipping monocline. This border of gentle folding lies along the Alamosa fault, San Ignacio monocline, and reservoir fault, at the southeast rim of the San Juan Basin.

Sheet basalts lie on erosion surfaces that truncate the northward-dipping and gently undulating strata east of the McCarty syncline. The warping is accordingly interpreted as probably contemporaneous with the folding of the syncline.

The faults in the north half of this portion of the field are paralleled by several basaltic dikes. There is, however, no alinement of the necks, and apparently none of these intrusions followed the faults as concuits to the surface. The faults seem related to the bloc'r faults in the Basin and Range part of the field, for they certainly show a marked parallelism of trends.

Little evidence is available to limit the date of the faulting in this gently warped part of the area. Along the north side of Chico Arroyo, 5 $5 \frac{1 / 2}{2}$ miles west of the Cerro de los Cuates, Cretaceous rocks are displaced 50 feet by a fault. However, gravel about 70 feet above the flood plain and 100 feet above the arroyo lies undisturbed across the fault. The final movements on this fault had therefore taken place prior to tha time when the stream.flowed 100 feet above its pres?nt position. If this faulting is contemporaneous with the fault along the southwest side of Horace Mesa the faulting occurred while the drainage system vras between 100 and 900 feet above its present position.

The part of the area between Mesa Chivato and Mesa Prieta was the scene of extensive volcanism when the sheets of basalt were erupted. These volcanic flows thus rose through the gently warped series of rocks and not through the folded and faulted area northwest of the McCarty syncline or the severely faultec Basin and Range part of the volcanic field. 


\section{BASIN AND RANGE PORTION OF THE FIELD}

\section{GENERAL STRUCTURAL RELATIONS}

The most striking structural feature of the Mount Taylor volcanic field is the sharp boundary between the Basin and Range and Colorado Plateau portions of the field. The boundary is marked by the Alamosa fault, San Ignacio monocline, and Reservoir fault (pl. 7), which have dropped the much-faulted and steeply tilted rocks to the east with respect to the gently warped rocks of the plateau. There is practically no transition zone between the areas showing the two types of deformation.

The trace of the Alamosa fault was not found, but its position locally can be determined within a fewhundred feet. The displacement is between 2,000 and 2,500 feet (pl. 18,A). The fault dies out toward the north, but the displacement is maintained by the faulted San Ignacio monocline, which has an average dip of about $40^{\circ} \mathrm{E}$. (pl. $18, B$ ). The monocline in turn dies out northward in a series of small faulted folds (pl. 7). Where the San Ignacio monochine dies out an arbitrary boundary line between the two provinces must be drawn eastward to the Reservoir fault, which, like the other boundary faults, drops the rocks in the Basin and Range province with respect to the Colorado Plateau part of the volcanic field. The Reservoir fault dies out northward in the southward-plunging folds produced by the Nacimiento uplift.

Several hundred faults are exposed in the Basin and Range portion of the Mount Taylor volcanic field. Most of these are small, but some produce displacements of a few thousand feet. So far as known all the faults are normal, and the displacement is generally down to the west. The faults commonly dip west at only moderate angles. The Ojo Escondido fault, for example, at one locality produces a displacement of 3,000 feet, and the fault dips only $45^{\circ} \mathrm{W}$. Several of the smaller faults, such as the Ojito fault, have equally moderate west dips.

Evidently the fault surfaces are very irregular. The dips of some faults change as much as $35^{\circ}$ in short distances along the strike. Other faults have sinuous traces across areas of low relief. Striae on the fault surfaces can rarely be found, because the faulted rocks are very friable. The fow striae observed are at high angles. These relations suggest that'movement on the faults was chiefly vertical.

There is a striking parallelism of the fault traces, the vast majority of which trend N. $10^{\circ}-15^{\circ}$ E. The apparent fault dips show less parallelism.

Very few of the faulted blocks have been folded. In general there is a fairly uniform east dip within any single block, but the amount of dip in different blocks is highly variable.

The following descriptions are confined to only a few of the most striking structural features.

\section{FAULTS}

The Ojo Escondido fault, in the Antonio Sedillo grant, pursues a sinuous course across an area, of little topographic relief. It is a normal fault, with the west block dropped. The displacement increases northward to about 3,500 feet where the fault passes under cover of the Santa Fe formation. Locally along the fault there is a shattered zone, as much as 300 feet wide. The material in this zone ranges in size from finely crushed rock to boulders measurable in scores of feet. Where the zone thins out and the fracture is a single clean break the fracture surface dips $70^{\circ}-45^{\circ} \mathrm{W}$.

The Suwanee fault, about $21 / 2$ miles west of the Ojo Escondido fault, also has considerable stratigraphic displacement down to the west. Where it emerges from alluvial cover at the south, the trend of the fault is N. $10^{\circ} \mathrm{E}$. and the displacement is 500 feet. A mile to the north the fault trends N. $20^{\circ} \mathrm{E}$., and where the fault passes under cover at the north the disf lacement is increased to nearly 1,200 feet.

East of San Ignacio there are nine nearly parallel faults, in general producing steps down to the west. The most westerly of this group, the Ojito farlt, has a stratigraphic displacement of 500 feet and dip $45^{\circ}-50^{\circ}$ W. Most of the other faults dip between $70^{\circ}$ and $85^{\circ}$.

The San Fernando fault is traceable for onl ${ }^{r}$ a short distance in T. 12 N., R. $1 \mathrm{~W}$. It is worthy of special mention because with the exception of the boundary faults it is the one fault known to have corsiderable stratigraphic displacement down on the east side. The amount of the displacement is uncertain, although it is probably near 1,500 feet. Locally along the fault there are zones of shatter 200 feet wide. Southward the fault branches into several minor faults. To the north it passes under cover.

The Garcia fault, concealed except in secs. 30 and 31 , T. 14 N., R. 1 E., has a minimum stratigre phic displacement of 2,200 feet down to the west. The true figure is probably nearer 3,000 feet. The fault is poorly exposed and passes under the cover of the Santa $\mathrm{Fe}$ formation both to the north and to the soutl.

\section{FOLDS}

The southern part of the block that is faulted down by the Ojo Escondido fault has been folded into $\varepsilon$, syncline whose axis trends about N. $45^{\circ}$ E. and plunges northeastward into the fault.

In the southeastern part of T. 12 N., R. 3 W., there is a northward-trending syncline a short distance east of the San Ignacio monocline.

At the north edge of the Basin and Range prit of the volcanic field two synclines and an anticline plunge southward. These are exceedingly sharp folds, but they are within the area deformed by the Nacimiento uplift and can be regarded as features related to that uplift, so that similar folds are not to be expected farther south in the area of block faulting. 


\section{AGE OF THE DEFORMATION}

The structural movements in the Basin and Range part of the Mount Taylor volcanic field can be closely dated with respect to the Santa $\mathrm{Fe}$ formation, generally regarded as of late Miocene and Pliocene age, which in this field is overlain by deposits of probable Pleistocene age (p. 56). The major movements of faulting had clearly preceded Santa $\mathrm{Fe}$ deposition in the eastern part of the volcanic field, but the latest movements involved the lower part of the formation. There is invariably a distinct angular unconformity between the Santa $\mathrm{Fe}$ and the Cretaceous beds, and the latter dip much more steeply. Rarely is there a pronounced difference in strike. Faults displacing the Santa $\mathrm{Fe}$ beds almost invariably displace the Cretaceous by considerably greater amounts.

These relations are well exposed throughout the northeastern part of the field. For example, in sec. 4 , T. 14 N., R. 1 E., the Cretaceous has been tilted $30^{\circ} \mathrm{S}$., but the overlying base of the Santa Fe has been tilted only $7^{\circ}$ in the same direction (pl. $17, D$ ). A mile east of this locality the Cretaceous beds strike N. $40^{\circ} \mathrm{E}$. and $\operatorname{dip} 18^{\circ} \mathrm{SE}$., whereas the overlying Santa Fe strikes N. $70^{\circ} \mathrm{W}$. and dips $10^{\circ} \mathrm{SW}$. (pl. $17, C$ ).

The best example of the relation of the Santa Fe to the faulting is found just outside the mapped area, a few hundred feet north of State Highway 44, about half a mile west of San Ysidro. Here Upper Cretaceous beds have been faulted down about 2,500 feet on the east against Triassic or Permian red shale, whereas the Santa Fe formation and the erosion surface beneath it have been displaced only 7 feet by the fault (fig. 14).

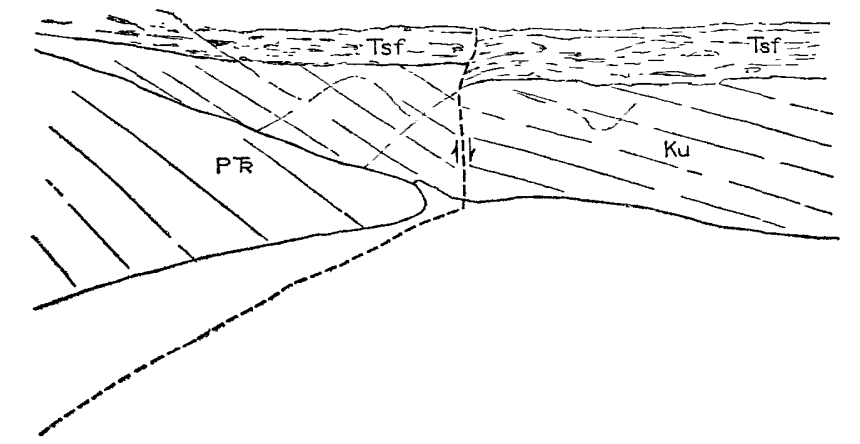

FIGURE 14.--Sketch from photograph showing fault relations half a mile west ot San Ysidro and 1,000 feet north of State Highway 44. Cretaceous rocks (Ku) faulted down about 2,500 feet against Permian or Triassic $(P \bar{k})$. The base of the Santa $\mathrm{Fe}$ formation (Tsf) has been displaced 7 feet.

Locally the Santa Fe formation lies nearly horizontal on faulted and tilted Cretaceous formations, as at the locality in the Antonio Sedillo grant shown in plate $19, A$.

The Santa Fe does not extend westward into the plateau part of the volcanic field, nor are the sheet basalts known to extend eastward out of the plateau. Indirect evidence, however, indicates that the sheet basalts were roughly contemporaneous with the overlap of the Santa $\mathrm{Fe}$ into the Basin and Range part of the Mount Taylor volcanic field, and that the basalts were erupted after the major fault movements but were involved in the latest deformation. The basalts and underlying erosion surfaces extend eastward nerrly to the edge of the plateau, as at Mesa Lucero, south of the field, and at Mesa Prieta. Figure 15 illustrates these relations. Evidently most of the movement along the fault shown in the figure preceded the cutting of the erosion surface beneath the sheet basalt. If it were

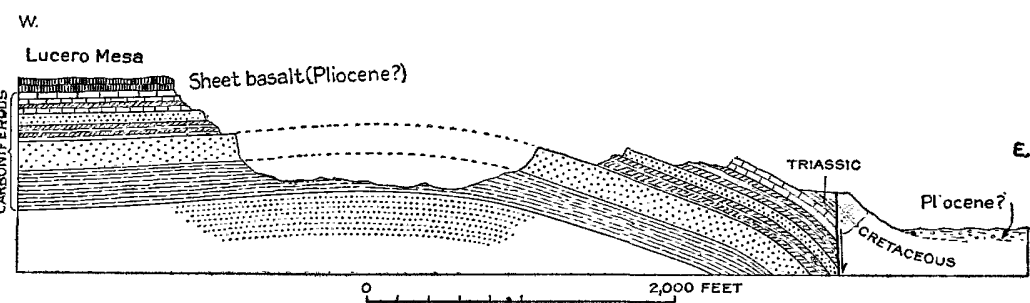

n illustrating faulting east of Mesa Lucero. After Darton. The basalt and the erosion surface on which it lies are probably younger than the fault at the right. (See also fig. 8 , p. 57 .) assumed that the faulting followed the cutting of the erosion surface, then a reconstruction of the pro-fault relations would show Cretaceous rocks capping a westward-facing scarp 2,000 feet higher than the erosion surface. This scarp would have been about 50 miles long, and the assumed later faulting would have coincided with it. This assumption of the fault coinciding with an extensive 2,000-foot scarp is improbable.

Other evidence, however, cited below, indicates that the basalt did not entirely escape the fault movements.

1. One tilted and faulted basalt flow, interbedde 1 with the lower part of the Santa Fe, is known in the Basin and Range part of the volcanic field (p. 70).

2. The erosion surface beneath the Santa $\mathrm{Fe}$ at the fault locality near Highway 44, half a mile west of San Ysidro slopes away from Sierrita Mesa, in the Nacimiento Mountains. The surface is about 50 feet above the flood plain of Arroyo Salado and about 100 feet above the stream bed and is only 2 to 6 mile from the nuclear area. Certainly this surface is younger than the basalt-capped surface on Mesa Prieta, wlich is about 900 feet above the present drainage level and 20 to 30 miles from any known nuclear area. The lower erosion surface is displaced 7 feet by a large fault. The formation of the higher surface therefore must have preceded the latest structural movements in the Basin and Range part of the field.

3. Minor faults in the eastern part of the $\mathrm{Co}^{1}$ nrado Plateau portion of the volcanic field are parallel to the set of faults in the Basin and Range part of the field, and these minor faults locally displace the old sheet basalts (p. 75).

The structural history of the Mount Taylor volcanic field may, then, be summarized as follows: The northward tilting of the southern San Juan Basin, the devel- 
opment of the McCarty syncline, and probably also the folding and associated faulting northwest of the $\mathrm{Mc}$ Carty syncline and gentle warping in the eastern part of the Colorado Plateau portion of the volcanic field had all been concluded before Mount Taylor erupted. This deformation ended probably before late Miocene time. However, it began later than early Eocene time, because far to the north, in the interior of the San Juan Basin, the Wasatch formation was tilted northward. Probably the faulting in the Basin and Range part of the volcanic field began at about the same time, but this faulting continued through later Tertiary time. The eruptions of Mount Taylor and the later sheet basalts were followed by minor folding and faulting within the McCarty syncline, south of Mount Taylor, minor faulting in the gently warped area east of the syncline, and continued faulting and tilting in the Basin and Range part of the volcanic field. These final movements began in Pliocene time and probably continued into Pleistocene time.

\section{PUSSIBLE SIGNIFICANCE OF THE STRUCTURAL FEATURES}

The presence in the southern San Juan Basin of broad areas with gentle homoclinal dips implies the absence of active compressive stresses in the stratified rocks. It is hardly conceivable that the weak stratified upper crust of the southern San Juan Basin could transmit stresses without considerable deformation. Probably there was compression deep in the crystalline basement, but deformation of the weak stratified formations was apparently in the main an adjustment to irregularities developed in the upper part of the basement rocks. Renick ${ }^{13}$ suggests that the Nacimiento uplift was thrust west because the basement rocks were uplifted sufficiently to allow their being pushed westward against the weak stratified formations. The same interpretation may be applied to the linear folding in the Gallup-Zuñi Basin, west of the Zuñi uplift. ${ }^{14}$

The stratified formations overlying an arch of basement rocks would be stretched and fractured, probably by normal faulting. The close relationship of faulting to folding in the northwestern part of the Mount Taylor volcanic field has already been cited (p. 75) and perhaps resulted from such a process. The deformation of the southern San Juan Basin was at a maxinum beneath the Mount Taylor volcano and diminished progressively westward, suggesting that the assumed deep stresses were active from the east. The asymmetry of the Zuñi and Nacimiento uplifts and the

\footnotetext{
13 Renick, B. C., Geology and ground-water resources of western Sandoval County, N. Mex.: U. S. Geol. Survey Water-Supply Paper 620, p. 71, 1931.

14 Sears, J. D., Geology and coal resources of the Gallup-Zuñi Basin, N. Mex, J. S. Geol. Survey Bull. 767, pl. 1, 1925.
}

westward thrusting of the Nacimiento further suggest active forces directed westward.

The following facts collectively suggest that at least the stratified rocks in the Basin and Range portion of the Mount Taylor volcanic field were deformed by horizontal tensional stresses or by stresses directed vertically:

1. So far as known the faults are all normal faults on which there was very little horizontal movement (p. 76).

2. The faults trend nearly parallel to the western limit of the faulting. Experiments indicate that horizontal shearing would have developed en échelor faulting.

3. The width of the faulted area apparently has been expanded by faulting and diminished by folding and tilting. To determine roughly the relative amounts of the expanding and shortening a computation was made along a 6 -mile line approximately coinciding with the south face of the block shown on plate 1.8, $A$. It was assumed that the dip of the fault surfaces continued at depth as observed at the surface. The computation accordingly indicates an east-west shortening of 1,600 feet by folding. The widening by faulting arounts to 2,800 feet. The net widening therefore would be 1,200 feet in 6 miles, or nearly 4 percent. A second computation was made along a line 5 miles in length about the position of the south face of the block shown in plate $18, B$. This computation indicates a widening by faulting of 1,000 feet and a shortening by folding of 250 feet, or a net widening of 750 feet, slightly less than 3 percent. It is fully conceded that these computations take cognizance only of those structural features that are recorded on a structure map having a scale of 1 mile to the inch and a 100-foot contour interval. Furthermore, the assumption of maintenance of dip br the fault surfaces is probably false. No claim is made that the figures even approach precision, but in the absence of other evidence they at least suggest that the area has been widened by a few percent.

Possibly the faulting resulted in part from deep folds arching the stratified rocks. Mesa Lucero and the southeast flank of the San Juan Basin may be interpreted as the west flank of a broad arch whose axis is in the down-faulted Rio Grande Valley, and the Sandia and Manzano Mountains as the east flank. But arching alone of the stratified rocks seems inadequate to explain fully the abundant faulting. Back of the westerly forces that produced the Zuñi uplift and the deformation beneath Mount Taylor there may have been fairly deep tension. However, it is more likely that an appearance of horizontal tension was produced by shearing of the surface rocks at a high ancle to the horizontal. 


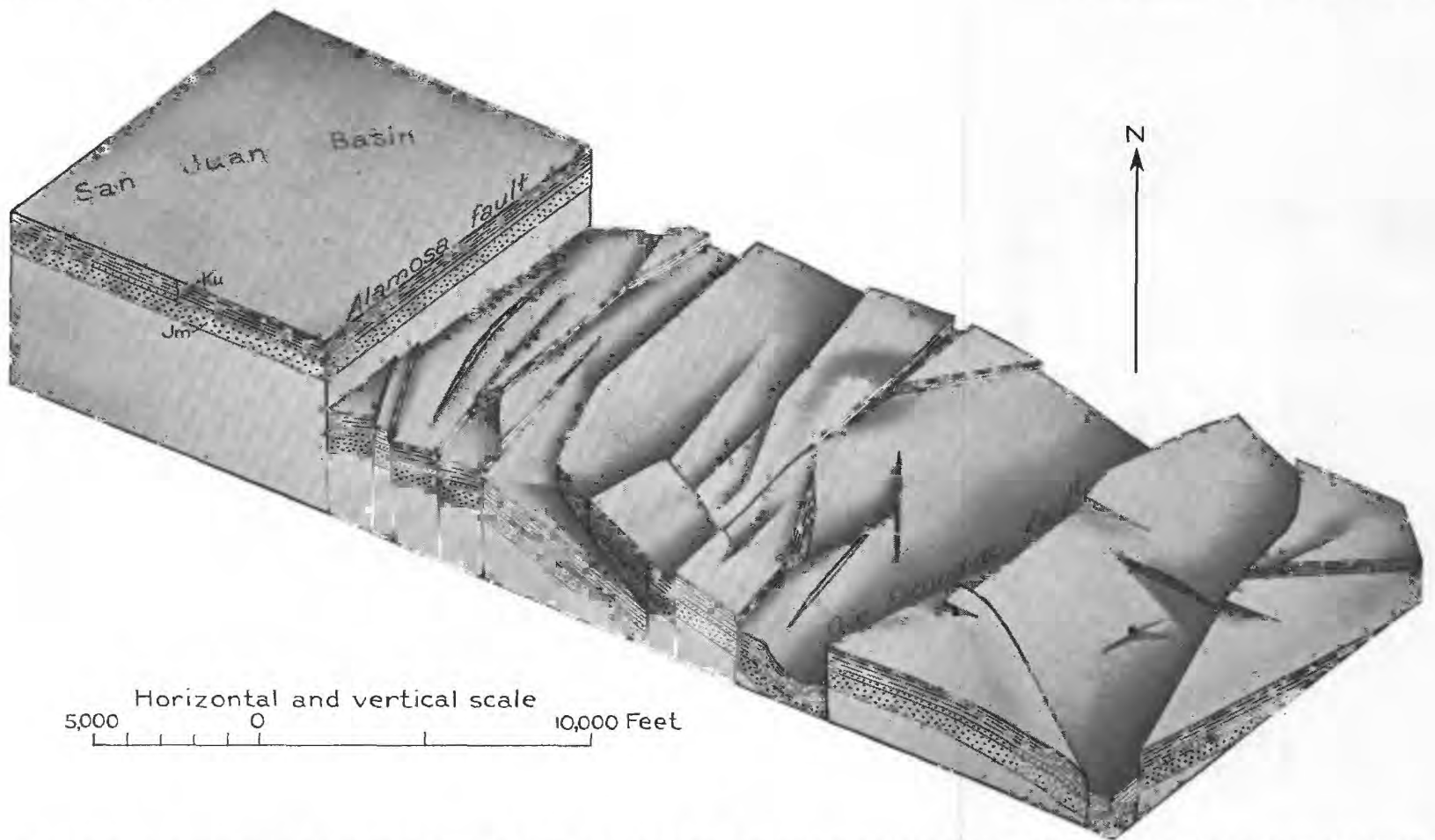

A. BLOCK DIAGRAM SHOWING STRUCTURAL SURFACE OF PART OF ANTONIO SEDILLO GRANT AT SOUTHWEST CORNER OF THE AREA. Isometric projection; vertical scale is not exaggerated. Shading by W. H. Bradley. Ku, Cretaceous shale; Jm, Jurassic sandstone.

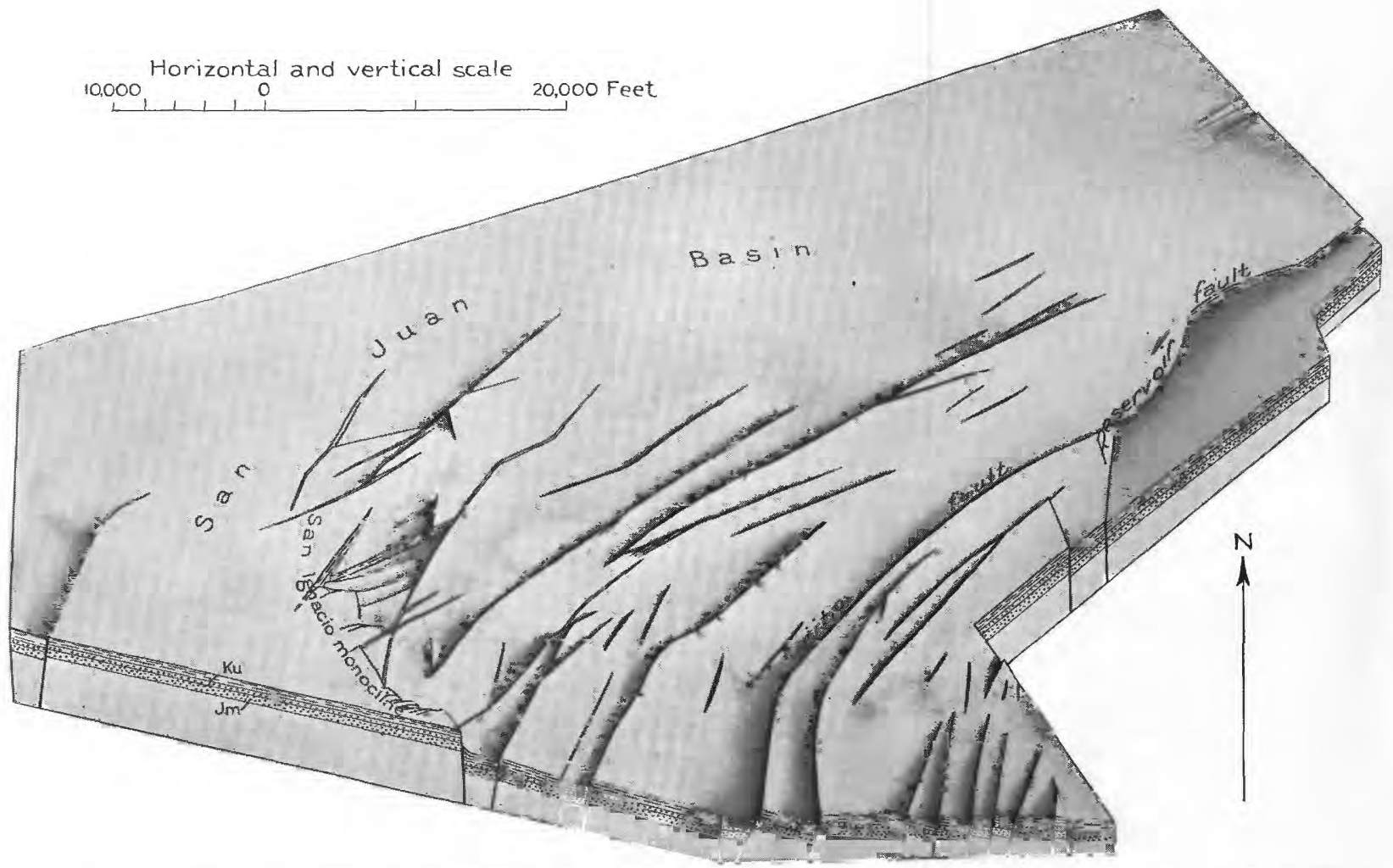

B. BLOCK DIAGRAM SHOWING STRUCTURAL SURFACE OF MOST OF NORTH HALF OF BASIN AND RANGE PART OF MOUNT TAYLOR VOLCANIC FIELD.

Isometric projection. Ku, Cretaceous shale and sandstone; Jm, Jurassic sandstone. 


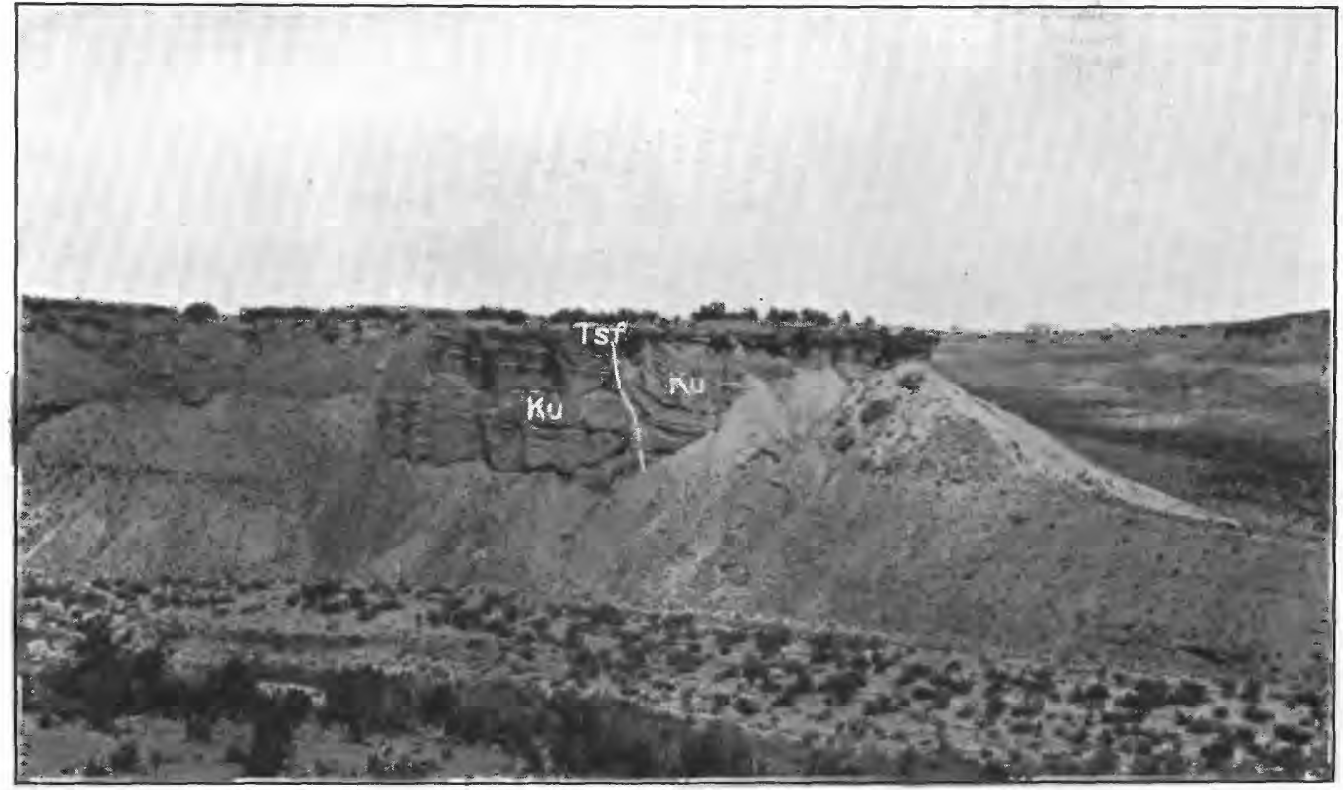

A. FLAT-LYING UNBROKEN SANTA FE FORMATION CROSSING A NORMAL FAULT IN CRETACEOUS SHALE View looking north in Sedillo Grant 2 miles northeast of Suwanee. Tsf, Santa Fe formation; Ku, Cretaceous shale.

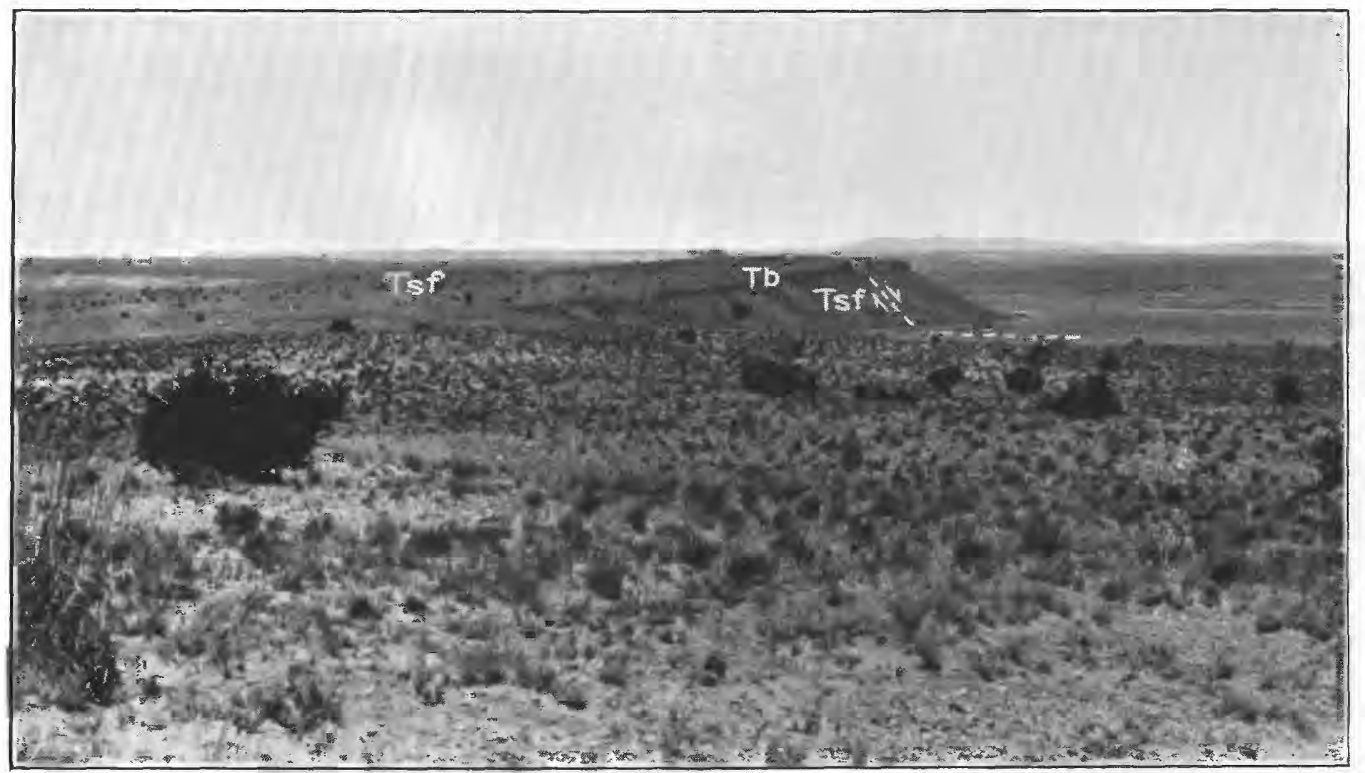

B. BASALTIC LAVA IN SANTA FE FORMATION TILTED AND BROKEN BY A SMALL FAULT. View along New Mexico State Highway 6 in sec. 2, T. 9 N., R. 1 W. Tsf, Santa Fe formation; Tb, basaltic lava. 